\title{
HYDROLOGY OF PARK COUNTY, WYOMING, EXCLUSIVE OF YELLOWSTONE NATIONAL PARK
}

By Marlin E. Lowry, Myron L. Smalley, and others

\section{U.S. GEOLOGICAL SURVEY}

Water-Resources Investigations Report 93-4183

Prepared in cooperation with the WYOMING STATE ENGINEER

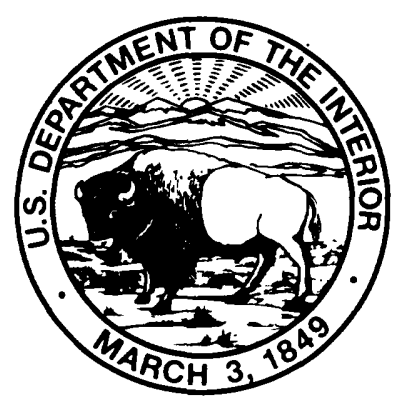

Cheyenne, Wyoming 


\section{U.S. DEPARTMENT OF THE INTERIOR \\ BRUCE BABBITT, Secretary}

U.S. GEOLOGICAL SURVEY

ROBERT M. HIRSCH, Acting Director

For additional information write to:

District Chief

U.S. Geological Survey

Water Resources Division

2617 East Lincolnway, Suite B

Cheyenne, Wyoming 82001-5662
Copies of this report can be purchased from:

U.S. Geological Survey

Earth Science Information Center

Open-File Reports Section

Box 25286, Denver Federal Center

Denver, Colorado 80225 


\section{HYDROLOGY OF PARK COUNTY, WYOMING, EXCLUSIVE OF YELLOWSTONE NATIONAL PARK}

By Marlin E. Lowry, Myron L. Smalley, and others

\section{U.S. GEOLOGICAL SURVEY}

Water-Resources Investigations Report 93-4183

Prepared in cooperation with the WYOMING STATE ENGINEER

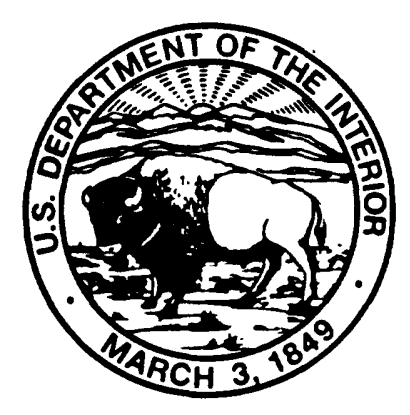

Cheyenne, Wyoming 


\section{U.S. DEPARTMENT OF THE INTERIOR \\ BRUCE BABBITT, Secretary}

U.S. GEOLOGICAL SURVEY

ROBERT M. HIRSCH, Acting Director

For additional information write to:

District Chief

U.S. Geological Survey

Water Resources Division

2617 East Lincolnway, Suite B

Cheyenne, Wyoming 82001-5662
Copies of this report can be purchased from:

U.S. Geological Survey

Earth Science Information Center

Open-File Reports Section

Box 25286, Denver Federal Center

Denver, Colorado 80225 


\section{CONTENTS}

Abstract
Introduction . Marlin E. Lowry
Description of the study area
$\quad$ Climate
Legal use of water
Richard G. Stockdale

Ground water......

Marlin E. Lowry

Ground-water data.

Occurrence and movement

Unconsolidated deposits

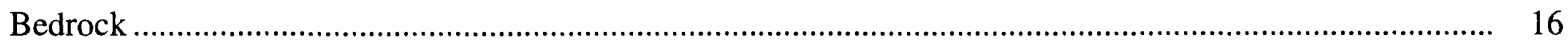

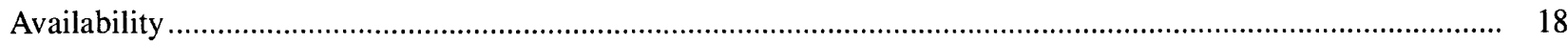

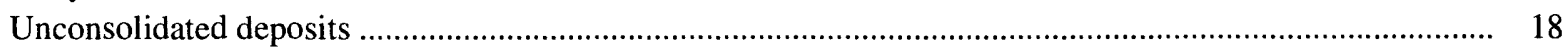

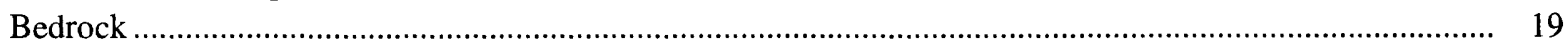

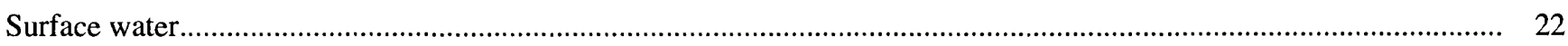

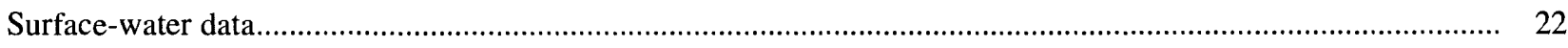

Michael Martin

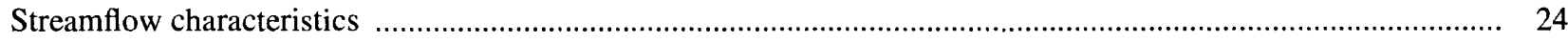

Myron L. Smalley

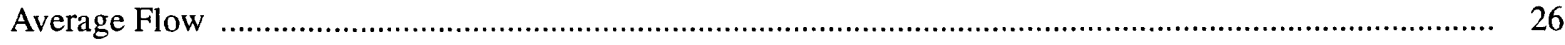

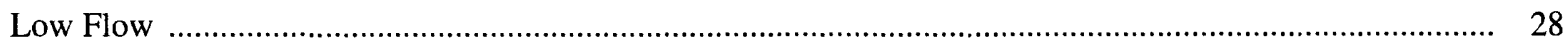

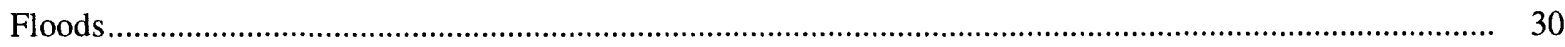

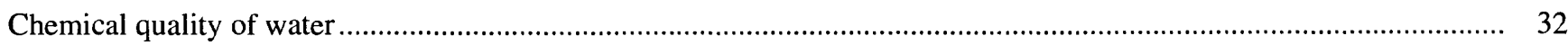

Marlin E. Lowry

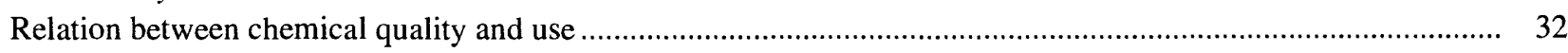

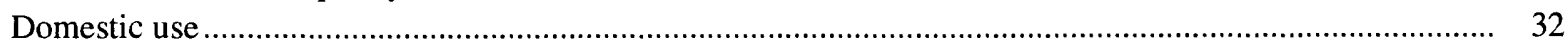

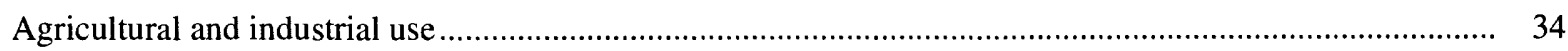

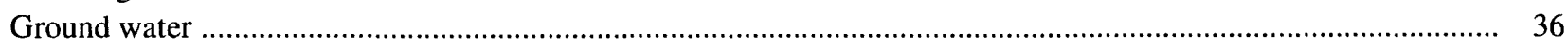

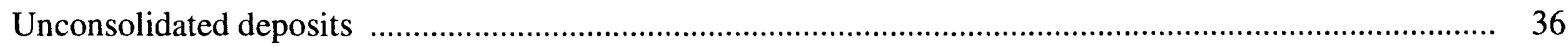

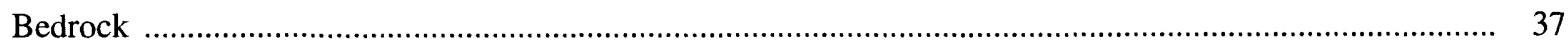

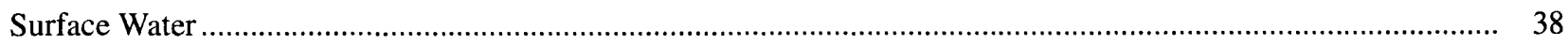

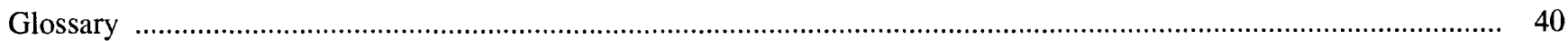

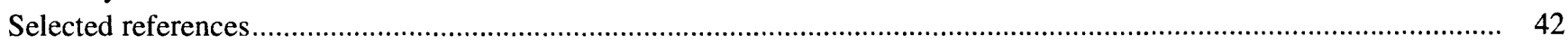

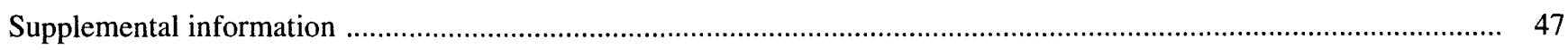

Description of geologic units and potential availability of ground water in Park County, Wyoming .................... 48

Index of surface-water sites and stations in Park County, Wyoming ............................................................ 54

Chemical analyses of ground water from selected wells and springs in Park County, Wyoming ......................... 58

\section{PLATE}

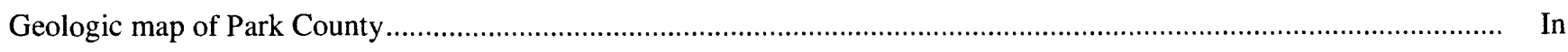


1. Index map of Wyoming showing area of this report and other reports in the county series that have been published or are in press, and studies in progress (1993)

2. Index map of Wyoming showing areas of reports in the U.S. Geological Survey Hydrologic

Investigations Atlas (HA) series

3. Block diagram of landforms and drainage.

4. Map showing general climate classification

5. Map showing average annual precipitation

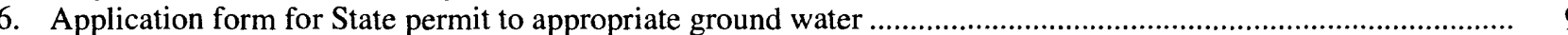

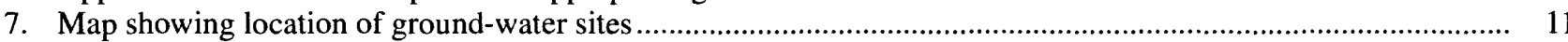

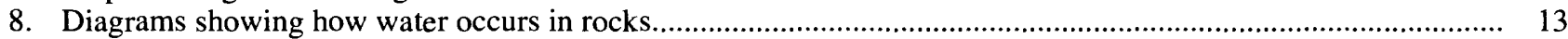

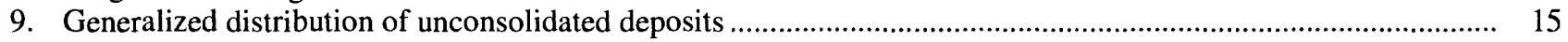

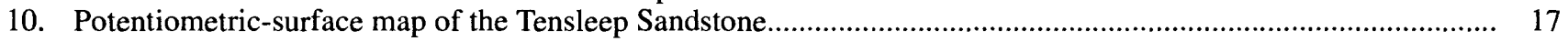

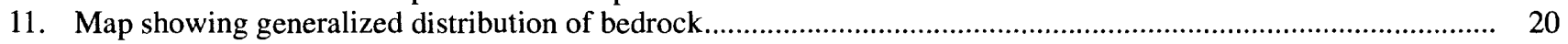

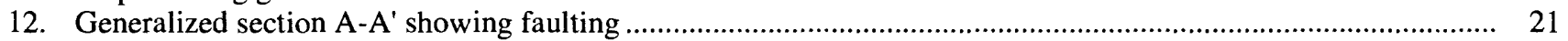

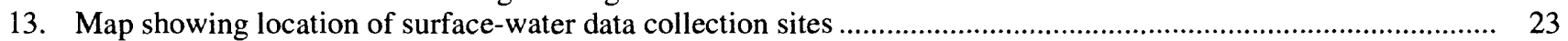

14. Flow-duration curves for South Fork Shoshone River near Valley and Fifteenmile Creek near Worland

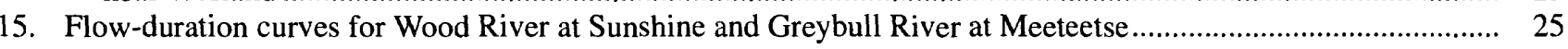

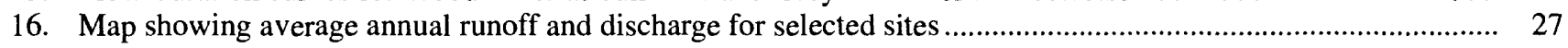

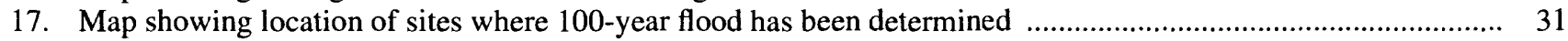

18. Diagram showing classification of ground water in Park County for irrigation use........................................... 35

19. Graph showing dissolved-solids concentration in water samples from unconsolidated deposits in Park County......

20. Graph showing dissolved-solids concentration in water samples from bedrock in Park County

21. Graph showing daily mean discharge and specific conductance of water in Bitter Creek near Garland, October 1980 through September 1981 Graph showing cumulative dissolved-solids load of the Shoshone River from

22. Graph showing cumulative dissolved-solids
below Buffalo Bill Reservoir to Lovell.

\section{Tables}

1. Seven-day low-flow data for selected sites in Park County

2. Drinking-water regulations for public water supplies for selected constituents. 
CONVERSION FACTORS AND VERTICAL DATUM

\begin{tabular}{rll}
\hline Multiply & By & To obtain \\
\hline acre-foot per square mile & & cubic meter per square kilometer \\
cubic foot per second & 476.1 & cubic meter per second \\
foot & 0.02832 & meter \\
gallon per minute & 0.3048 & liter per minute \\
inch & 3.785 & millimeter \\
mile & 25.4 & kilometer \\
square mile & 1.609 & square kilometer \\
\hline
\end{tabular}

Degrees Celsius $\left({ }^{\circ} \mathrm{C}\right)$ may be converted to degrees Fahrenheit $\left({ }^{\circ} \mathrm{F}\right)$ by using the following equation:

$$
{ }^{\circ} \mathrm{F}=9 / 5\left({ }^{\circ} \mathrm{C}\right)+32
$$

Sea level: In this report "sea level" refers to the National Geodetic Vertical Datum of 1929 (NGVD of 1929)--a geodetic datum derived from a general adjustment of the first-order level nets of both the United States and Canada, formerly called "Sea Level Datum of 1929." 


\title{
Hydrology of Park County, Wyoming, Exclusive of Yellowstone National Park
}

\author{
By Marlin E. Lowry, Myron L. Smalley, and others
}

\section{Abstract}

Unconsolidated deposits are a principal source of ground water in Park County. However, the presence of water in deposits topographically higher than stream level depends on recharge from surface water used for irrigation. Terraces that are not irrigated, such as Polecat Bench, do not have saturated deposits from which water can be obtained. Water in the unconsolidated deposits, although dependent upon infiltration of applied surface water, is of poorer quality than the applied surface water because of solution of salts as the water moves through the soil.

The conversion of irrigated agricultural land to urban development poses problems in some areas because yields of water-supply wells will be adversely affected by reduced recharge. Water in unconsolidated deposits is at shallow depths, thus, the trend toward urban development increases the risk of contamination from septic tanks, petroleum products, and accidental spills of toxic and hazardous wastes.

Ground water suitable for domestic use is difficult to obtain in some areas where it is needed because of poor yields and poor quality in shallow aquifers. Large areas suitable for urban development are underlain by thick shales that have low well yields and poor water quality. Folding of rocks during the mountain-forming process in western Wyoming has resulted in some of the aquifers being too deeply buried to be considered as a source of water for either domestic or stock supplies. Although many of these aquifers may contain water of good quality near the surface, the quality usually becomes poorer with depth and is not suitable for domestic use.

Ground water is present throughout most of the county and most ground-water flow stays within the county. A small, unquantified amount of water flows through the county in the aquifers. The aquifers are continuous from the edges of the mountains into the badlands and plains and beyond county boundaries.

The climate of Park County varies from alpine tundra to desert. Altitudes range from 12,000 feet above sea level in the mountains to 4,015 feet where the Clarks Fork Yellowstone River flows into Montana. Annual precipitation averages up to 40 inches in the mountains, but only 6 inches near the eastern edge of the county.

Perennial streams in the county originate in the mountains; streams originating in badlands and plains are ephemeral unless they drain an area irrigated by surface water so that return flow is sustained during the winter. The average annual runoff of streams that originate in the mountains is as large as 598 acre-feet per square mile; for streams that originate in the badlands and plains, annual runoff is as low as 14.8 acre-feet per square mile. 


\section{INTRODUCTION}

\section{Report Summarizes Hydrologic Information for Park County, Wyoming}

An extensive list of references for additional information on the area is included.

Throughout Wyoming there is a need for basic hydrologic information-particularly about ground water-for water planning and management at the local (county) level. In order to provide such information, the U.S. Geological Survey (USGS), in cooperation with the Wyoming State Engineer, has resumed the series of county studies started in the 1950's and suspended in the 1970's.

The cooperative program between the USGS and the Wyoming State Engineer to describe and assess the ground-water resources of the State began in 1945. In addition to detailed studies of smaller areas, the program has included studies of many Wyoming counties and of much larger areas-the major structural basins. The counties covered by previous or current investigations (1993) are indicated in figure 1. The studies of major structural basins, completed during the 1960's and 1970's, are reported in the USGS Hydrologic Investigations Atlas series (fig. 2).
This report summarizes hydrologic conditions in Park County, Wyoming (fig. 1) and provides a description of sources of additional information about the area. The study focused on supplementing information from earlier studies.

The area of Park County covered by this report is east of 110 degrees longitude, which approximates the eastern edge of Yellowstone National Park. The reader who wishes information for the area of the county west of 110 degrees is referred to the USGS Hydrologic Investigations Atlas by Cox (1976).

Ground-water, surface-water, and water-quality information are described in an easy-to-read format for citizens, planners, and managers interested in Park County. The format consists of a brief text with an accompanying page of illustrations or tabular data for each topic related to water resources. A glossary of hydrologic and geologic terms used in the report and an extensive list of references are provided. 


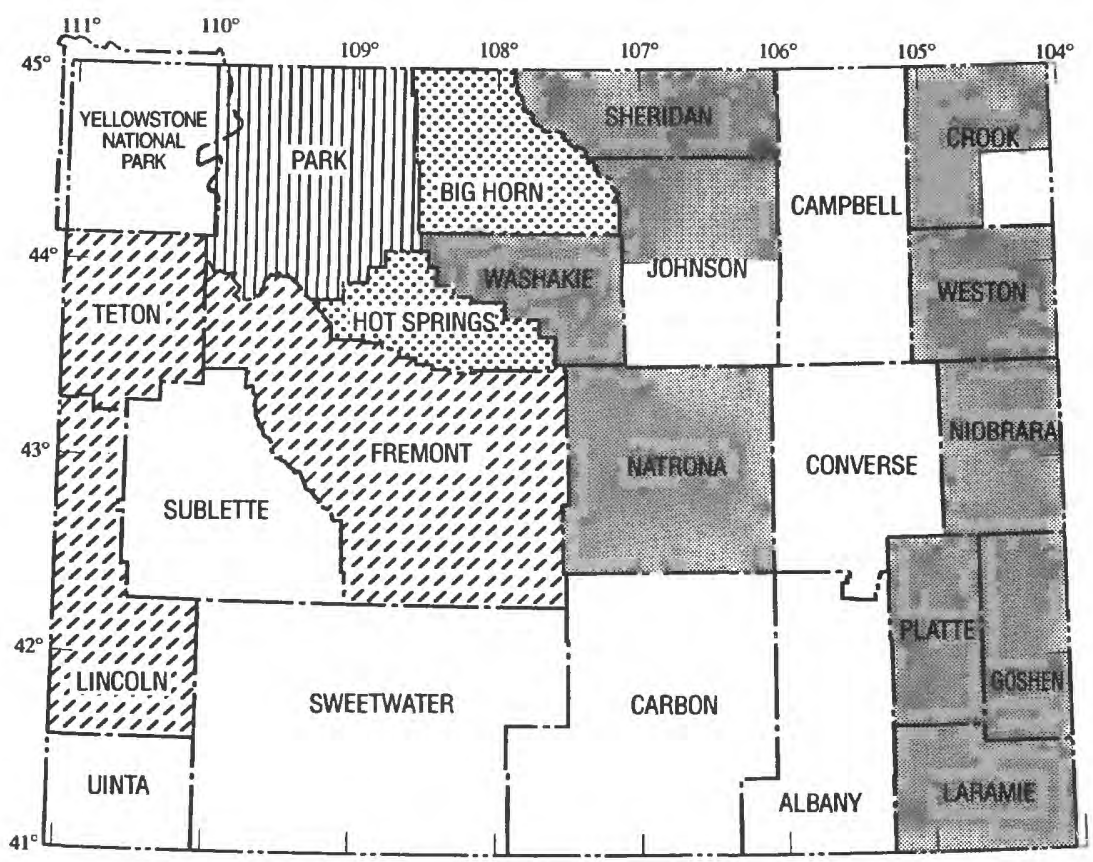

EXPLANATION

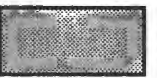

PUBLISHED
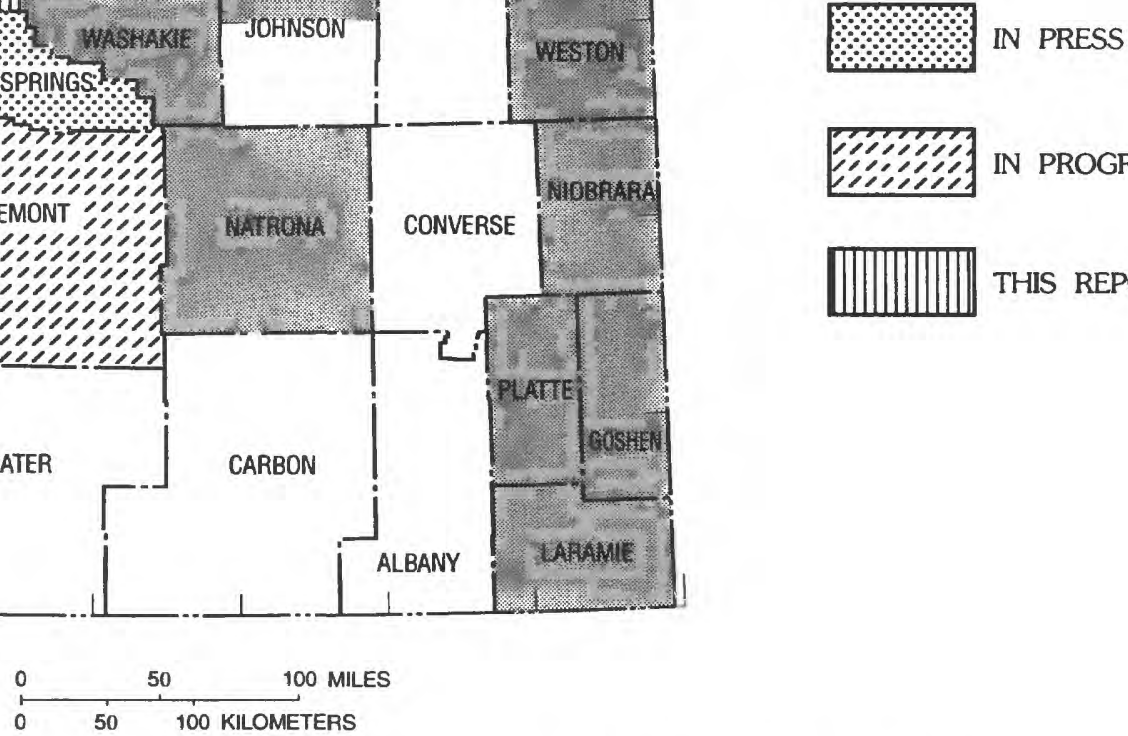

Figure 1.--Index map of Wyoming showing area of this report and other reports in the county series that have been published or are in press, and studies in progress (1993).

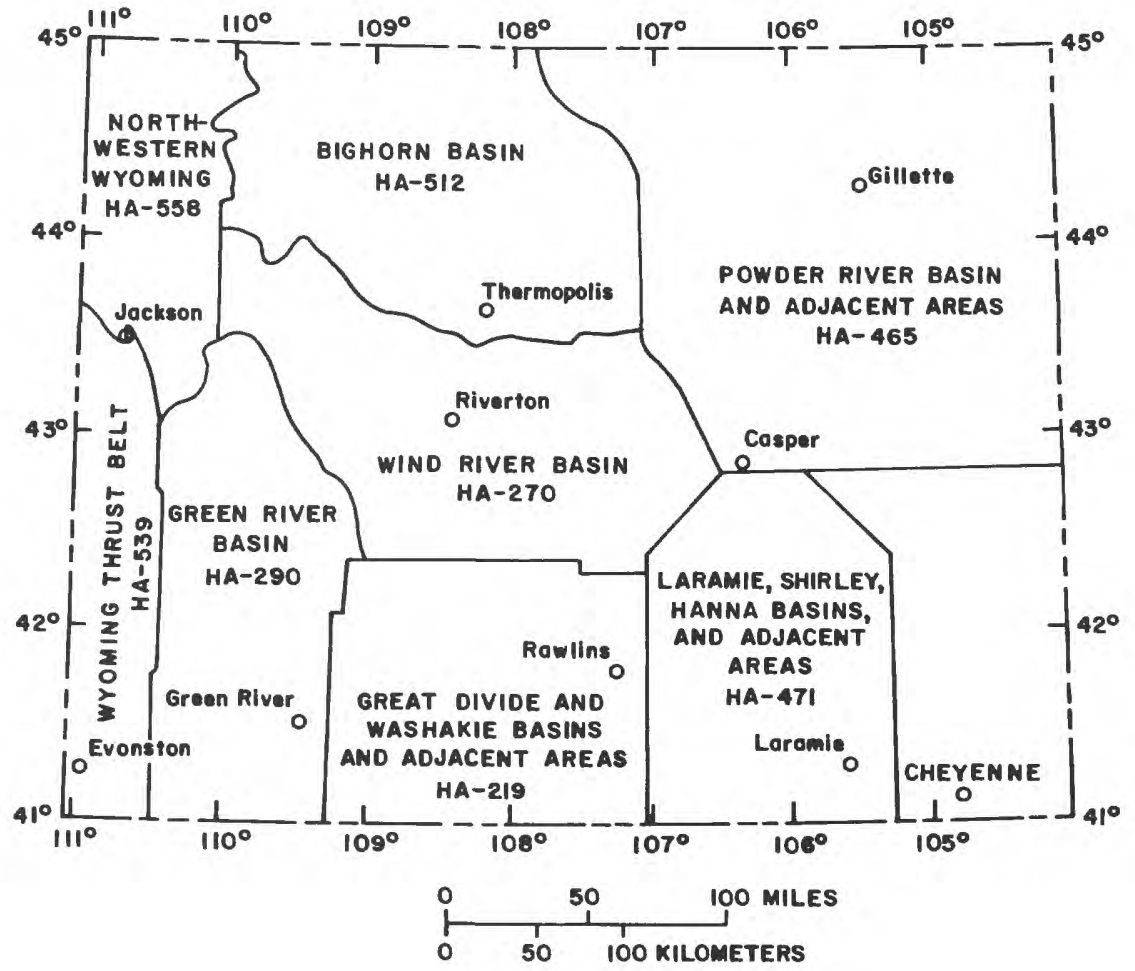

Figure 2.-Index map of Wyoming showing areas of reports in the U.S. Geological Survey Hydrologic Investigations Atlas (HA) series. 


\title{
DESCRIPTION OF THE STUDY AREA
}

\author{
Landforms and Drainage
}

\section{Terrain Varies From Mountains and Badlands to Terraces and Floodplains}

\author{
Drainage from the area is northward into the Yellowstone River \\ and eastward into the Bighorn River.
}

The terrain in the study area varies from mountains and badlands with steep slopes to comparatively flat and extensive terraces and floodplains (fig. 3--terraces and floodplains are not shown at this scale). Even in the mountains, distinct differences in terrain are apparent in figure 3 between the Beartooth Mountains, which are composed of igneous crystalline rocks, and the Absaroka Range, which is composed mostly of volcanic rocks. The highest mountain peaks commonly have altitudes more than 10,000 feet with some more than 12,000 feet. The lowest point in the county is in the Bighorn Basin, about 4,015 feet above sea level, where the Clarks Fork Yellowstone River flows into Montana (fig. 3).
In contrast to the steep slopes in the mountains and badlands, terraces and floodplains have much gentler slopes. The terraces and floodplains are related to streams and therefore are primarily linear, with widths generally less than 2 miles.

The county is within the Missouri River drainage basin. The northern part of the county is drained by Clarks Fork Yellowstone River and its tributaries, which flow northward to the Yellowstone River in Montana. Most of the remainder of the county is drained by the Shoshone and Greybull Rivers and Fifteenmile Creek, which flow eastward to the Bighorn River. 


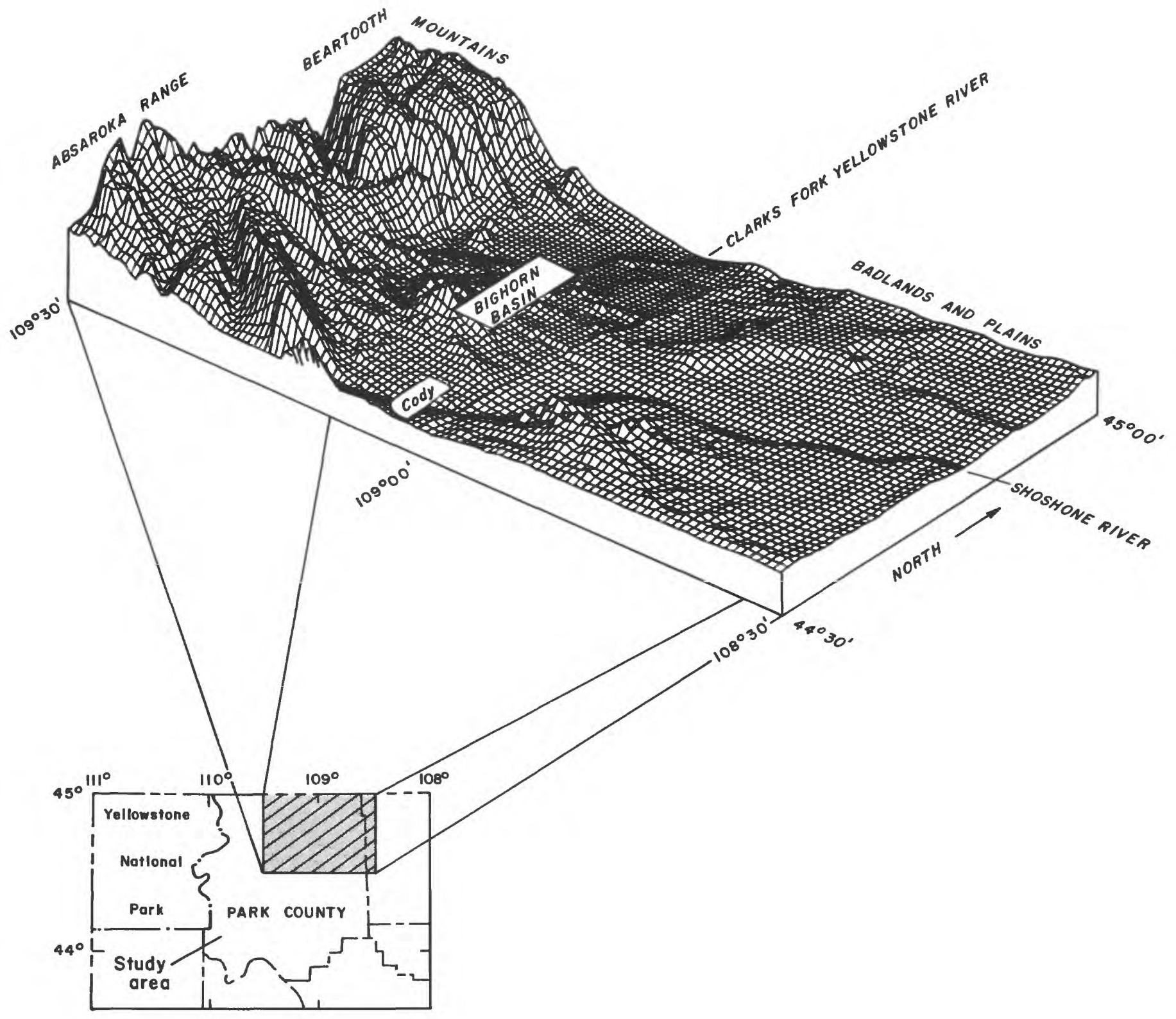

Figure 3.-Block diagram of landforms and drainage. 


\section{DESCRIPTION OF THE STUDY AREA-Continued}

Climate

\section{Topography Affects Climate}

Average annual precipitation in the county varies from 6 to 40 inches.

The climate of the county varies from alpine tundra and alpine in the mountains to steppe and desert in the badlands and plains, as shown in figure 4 (Martner, 1986, p. 5). A principal cause of changes in climate is the difference in altitude. In this region, the effect on climate of an increase of 1,000 feet in altitude is equivalent to that of a northward displacement in latitude of about 300 miles.

The prevailing westerly winds explain the distribution of average annual precipitation in the county (fig. 5). The mountains on the western side of the county cause the air masses to rise, creating clouds and resulting in up to 40 inches average annual precipitation in the mountains. The air descends into the Bighorn Basin, and most of the clouds dissipate before reaching the eastern edge of the county, where the average annual precipitation is only 6 inches.

The driest period for Cody, Wyoming, is November through February, when about 15 percent of the annual 11.52 inches of precipitation falls (Martner, 1986, p. 316). The dominant air mass during this time is the continental polar air mass, which typically is cold and dry. The wettest period is April through June with about 50 percent of the average annual precipitation falling during this period. The dominant air mass during the summer is the maritime pacific air mass, which is warm and moist. Most precipitation from November through April is snow. Precipitation at other times occurs as light showers and occasional intense thunderstorms.

On the average, skies are clear 65 percent of the daylight hours. During winter, skies are clear about 50 percent of the time, and in summer they are clear about 75 percent of the time. Although sunshine prevails, cold air masses that flow into the county from the north sometimes stagnate in the area, causing prolonged cold (Peterson and others, 1987, p. 6). 


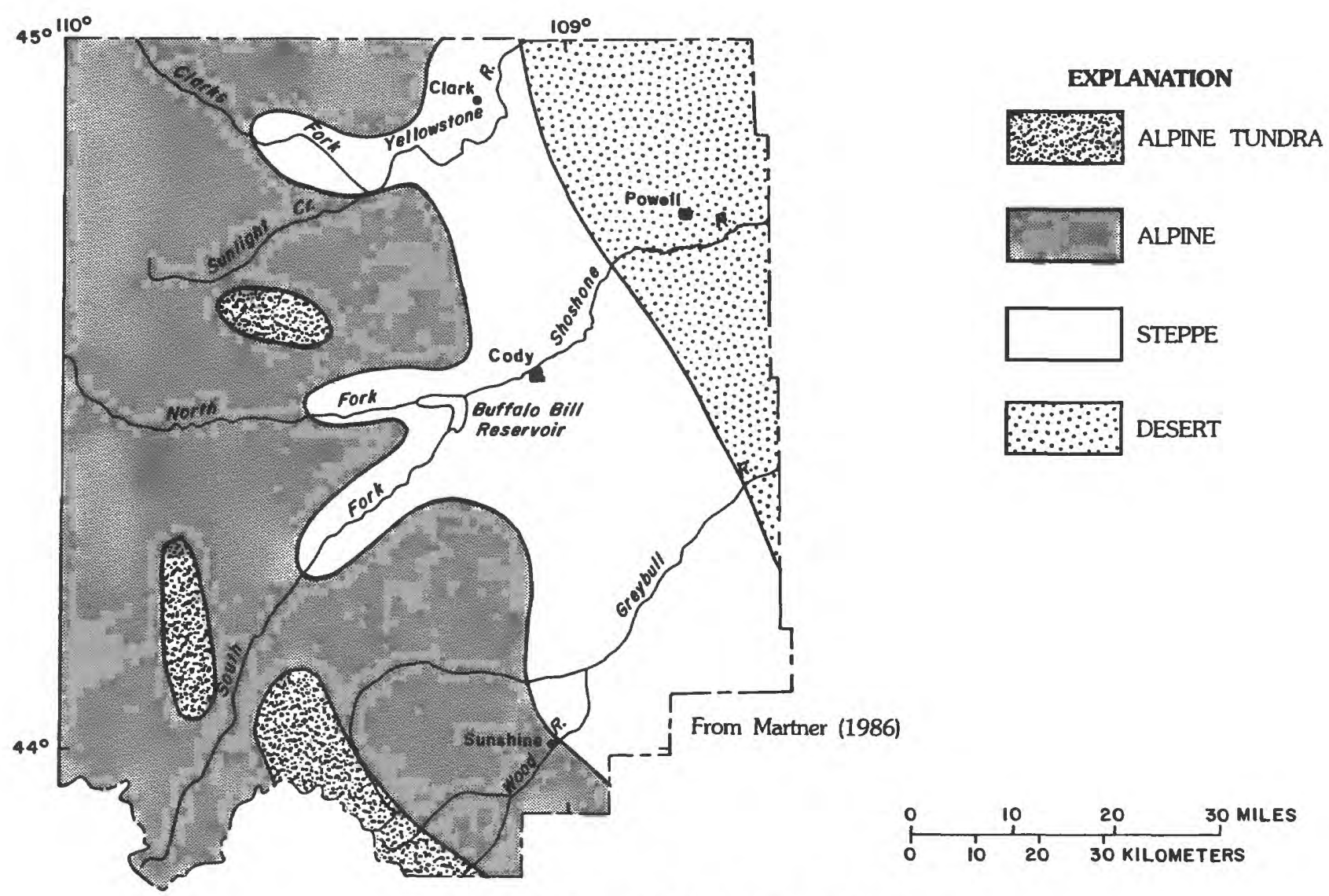

Figure 4.--General climate classification.

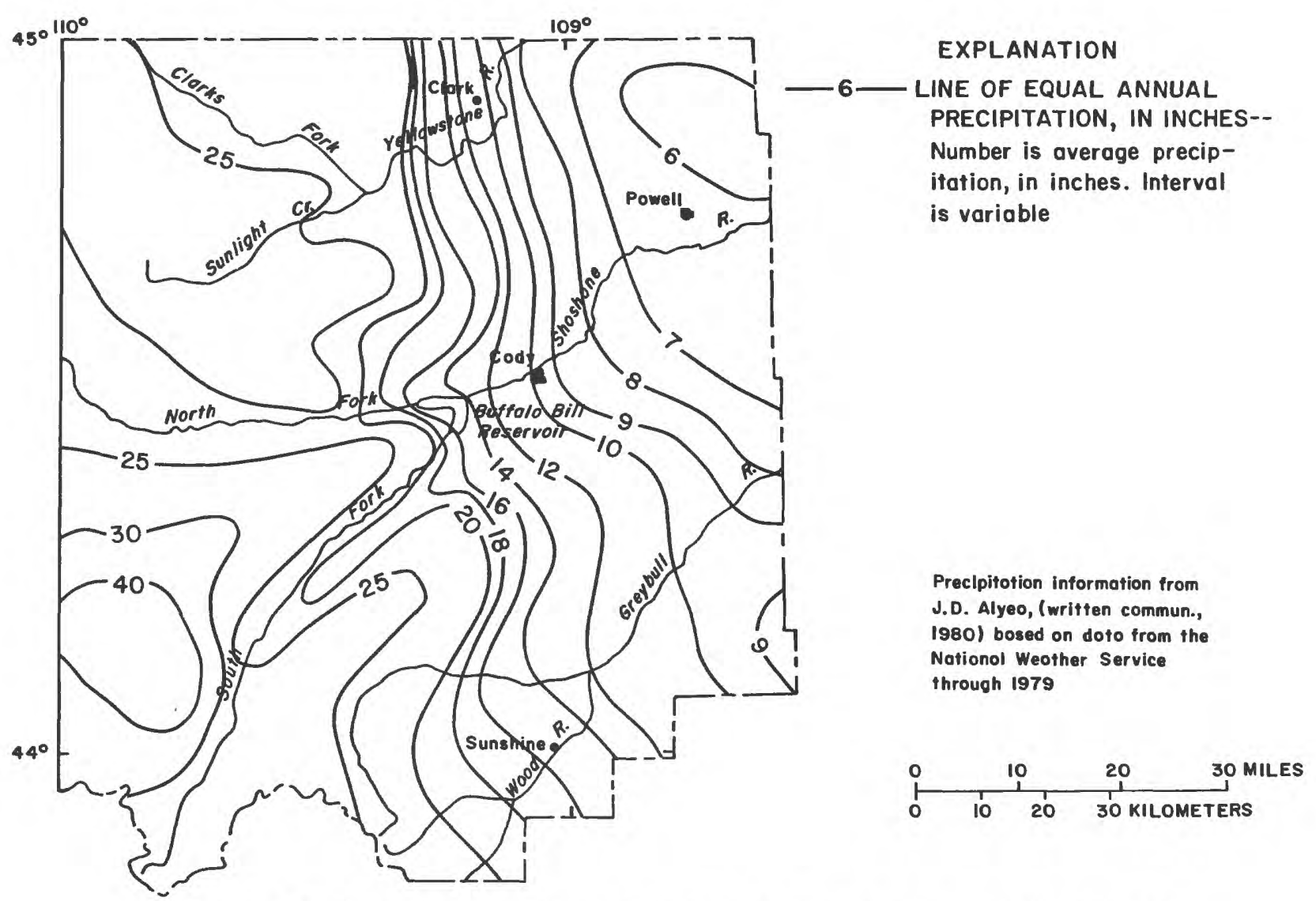

Figure 5.-Average annual precipitation (from Lowham, 1988, pl. 1b). 


\title{
State Permit Required for all Water-Diversion Structures
}

\author{
Water rights are administered using the "First in time, first in right" system.
}

The Wyoming State constitution states that "The water of all natural streams, springs, lakes or other collections of still water, within the boundaries of the state, are hereby declared to be property of the state," (article 8, section 1). Anyone desiring to use water beneficially in Wyoming must apply for and obtain an approved permit from the State Engineer to appropriate water prior to initiating construction of any kind of water-diversion structure, such as dams, headgates, spring boxes, and wells (fig. 6).

Once a permit to appropriate water has been obtained from the State Engineer, the permittee may proceed with construction of the water-diversion structure and with beneficial use of the diverted water for the purposes specified in the permit. Such diversion and beneficial use must be made in accordance with statutory provisions. After the permittee has beneficially used the diverted water for all of the permitted uses at all of the permitted point(s) or area(s) of use, proof of beneficial use is filed, and the water right is adjudicated (finalized). The adjudication process fixes the location of the water-diversion structure, and the use, quantity, and points or areas of use for the water right.

Wyoming water rights are administered using the Doctrine of Prior Appropriation, commonly referred to as the "First in time, first in right" system. Article 8, section 3 of the Wyoming constitution states: "Priority of appropriation for beneficial uses shall give the better right." The priority date of an appropriation is established as the date when the application for permit to appropriate water is received in the State Engineer's Office.
Water-right administration is conducted by the State Engineer and the Water Division Superintendents. The State Engineer is Wyoming's chief wateradministration official and has general supervision of all waters of the State. The state is divided into four water divisions. Each division has a superintendent, and a staff of hydrographers and water commissioners, who are responsible for the local administration of water rights and the collection of hydrologic data in their respective divisions.

Deviations from the standard water-right administrative system of "First in time, first in right" exist. Such deviations might be caused by conditions in compacts, court decrees, and treaties; or through the creation of special water-management districts. Virtually every stream exiting the State has some type of compact, court decree, or treaty that dictates to some degree how the appropriations on that specific stream are administered. While the interstate nature of ground water and the tributary interconnection of ground water with streams are recognized, compacts for aquifers are still in their infancy. The reason that few ground-water compacts exist is twofold. First, there is a lack of sound technical data on which to base appropriate administrative allocations of ground water between adjoining states, and second, there is not sufficient competition between Wyoming and adjoining states to require compacts for ground-water resources.

As the intrastate and interstate competition for water increases, the existing administration process and the structure may be modified. However, to change or to modify the basic tenants of Wyoming's water law will require constitutional amendments. 
FORM L.W. 5

Rev. 5-79

FILING FEE SCHEDLLE

ON REVERSE SIDE
STATE OF WYOMING

OFFICE OF THE STATE ENGINEER

HERSCHLER BUILDING

CHEYENNE, WYOMING 82002

APPLICATION FOR PERMIT TO APPROPRIATE GROUND WATER

FOR OFFICE USE ONLY

|PERMIT NO. L.W

WATER DIVISION NO. DISTRICT

I.W. DISTRICT

NAME AND NLMBER OF WELL

1. Name of applicant(s)

2. Address of applicant(s)

3. Name \& address of agent to receive correspondence and notices

4. Use to which the water will be applied: Domestic·[ ] Stock Watering [ Industrial [ | Miscellaneous [ ] (Describe completely and accurately)

5. Location of the well: (NOTE: Quarter-quarter (40-acre subdivision) MUST be shown. EXAMPLE: SE1/4NW1/4 of Sec. 12, Township 14 North, Range 68 West.) ${ }_{\text {T.__ N., R.__ County, }}$ W. of the 6th P.M. (or W.R.M.), W yoming. If located iil a platted subdivision, also provide Lot _ Block__ of the Subdivision (or Add'n) of

6. Mark the well location on the section grid to the right. LOCATION SHOWN IN ITEM 5 MUST AGREE WITH GRID. If the proposed well is for irrigation use. sketch and label all irrigation ditches and canals, stream, reservoirs and other wells. Indicate the point of use or lands to be irrigated from other sources.

7. Estimated depth of the well is____ feet.

8. MAXIMUM quantity of water to be developed and beneficially used:_gallons per minute. NOTE: If for domestic or stock use, this application will be processed for a maximum of 25 gallons per minute. SPRINGS: Only springs flowing 25 gallons per minute or less, where the proposed use is domestic or stockwatering, will be considered as ground water appropriations. After approval of this application, some type of artificial diversion must be constructed to qualify for a water right.

9. If use is not irrigation, mark the point(s) or area(s) of use in the tabulation below.

10. If for irrigation use:

a. Describe MAXIMLM acreage to be irrigated in each 40 acre subdivision in the tabulation below.

b. I I Land will be irrigated from this well only.

c. I | Land is irrigated from existing water right(s) with water from this well to be additional supply. Describe existing warer right(s) under REMARKS.

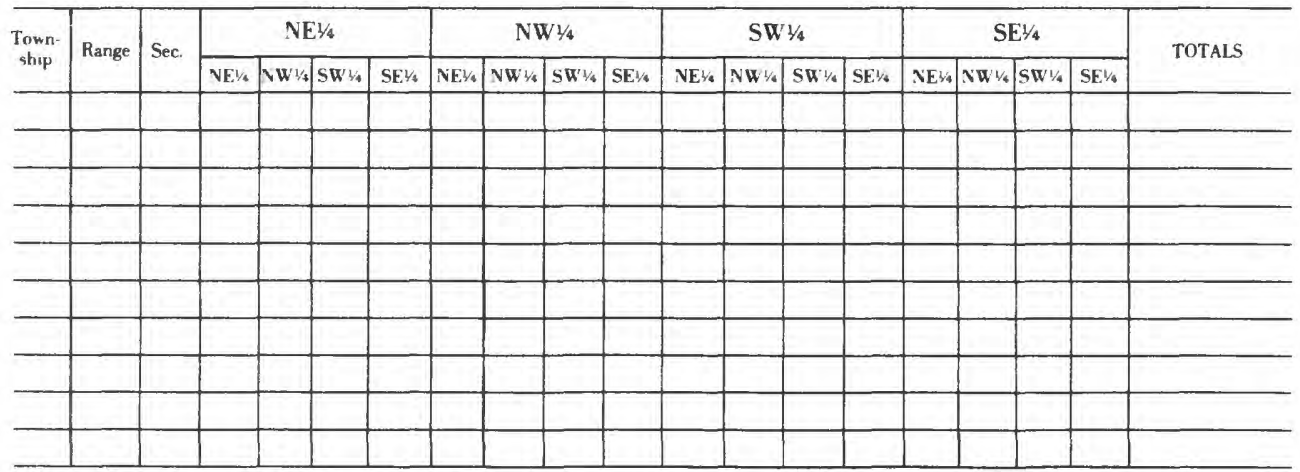

11. If for irrigation use. describe method of irrigation, i.e. center pivot sprinkler, flood, etc

Figure 6.-Application form for State permit to appropriate ground water (front page). Phone: Zip:

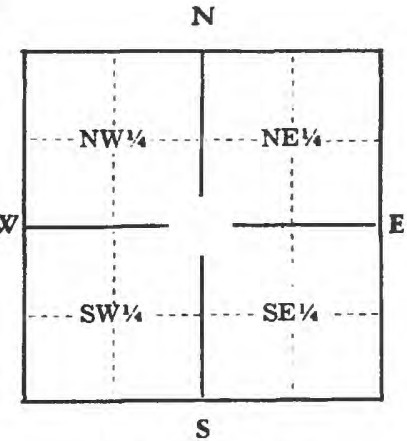

Scale: $2^{\prime \prime}=1$ mile section. Locate well accurately in

or print neatly with black ink.

LL ITEMS MLST BE COMPLETED
Above diagram represents one fuil section. Locate well accurately in
small square representing $40 \mathrm{ac}$.

BFORE APPLICATION IS ACCEPTABLE. 


\section{GROUND WATER}

Ground-Water Data

\section{Data Available for More Than 1,000 Ground-Water Sites}

The data available include well construction, water level, lithologic logs, yield, and chemical quality of water.

Information for more than 1,000 wells is filed in the offices of the U.S. Geological Survey and the Wyoming State Engineer. Most of the data is in computer files and includes information on well construction, water level, lithologic logs, yield, and chemical quality of water. However, only part of this information may be available for a specific site.
The distribution of ground-water sites is shown in figure 7. The distribution of wells closely corresponds to privately owned lands along major streams. Data are sparse for the mountains, where livestock grazing is the dominant land use and surface water generally is plentiful. In the interstream areas in the basin, livestock grazing is the dominant land use, but grass rather than water often is a limiting factor. 


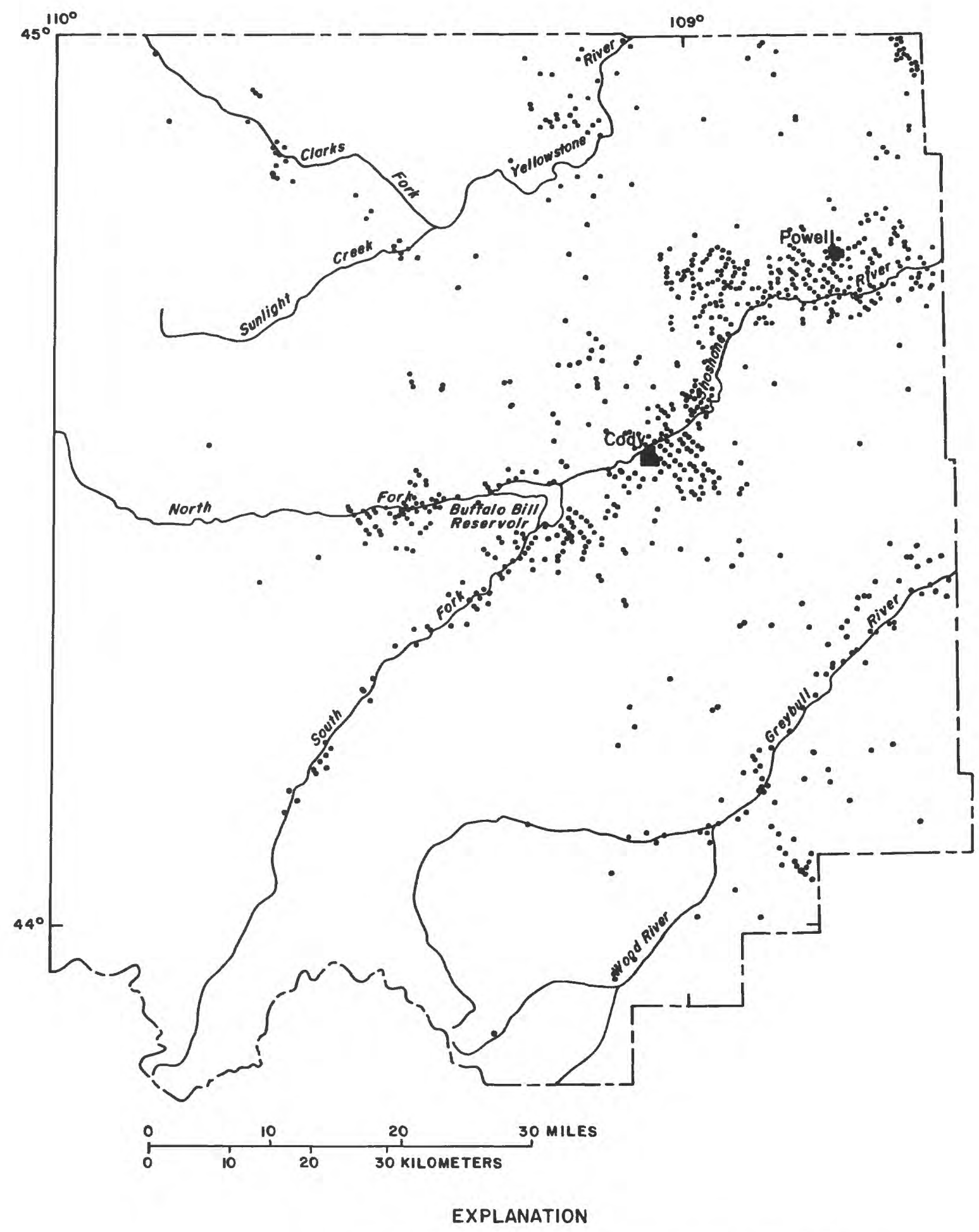

- SITE FOR WHICH GROUND-WATER INFORMATION IS AVAILABLE FROM U.S. GEOLOGICAL SURVEY OR WYOMING STATE ENGINEER

Figure 7.-Location of ground-water sites. 


\section{GROUND WATER--Continued}

Occurrence and Movement

\section{Quantity of Ground Water is Variable Throughout the County}

Occurrence and movement of water is related to the openings in the rocks.

\begin{abstract}
Although water is present at some depth everywhere beneath the land surface, the quantity of water that can be obtained from saturated rocks differs greatly both areally and, at most places, with depth. The ease of movement of water in the rocks (permeability) is related to the size of the openings between the rock particles and the interconnection between the openings. Openings can be classified as primarythose that formed at the time the rocks were deposited (for example, the openings between sand grains in sandstone); or secondary - those that formed subsequent to deposition (for example, fractures in granite or caverns in limestone) (fig. 8).

Rocks with small primary openings (and small grain sizes), such as shale and siltstone, may not pro-
\end{abstract}

vide much water to wells. Rocks with larger primary openings, such as sandstone or gravel, usually provide larger yields of water to wells. Secondary openings, such as fractures or solution openings, can hold and transmit much more water than primary openings. With increasing depth, compaction can decrease the primary openings.

Because the occurrence and movement of water is controlled by the properties of the rocks, the description of occurrence and movement of ground water in the following sections is based on geologic units. For this report, rocks in the area are grouped into two types of geologic units - unconsolidated deposits and bedrock. 
PRIMARY OPENINGS

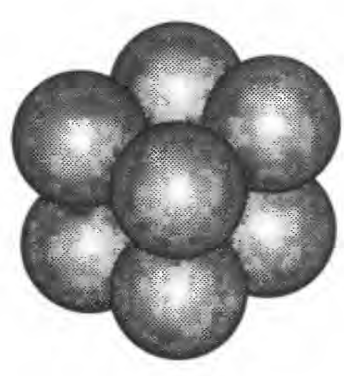

POROUS MATERIAL

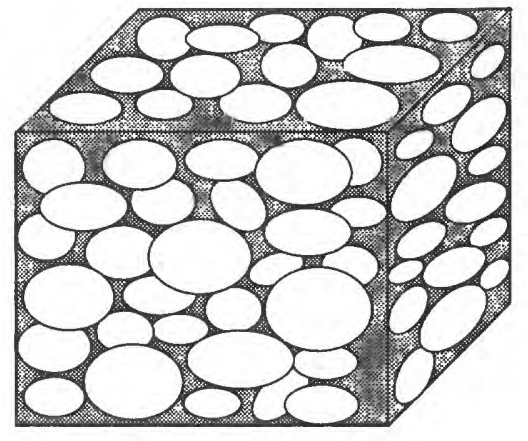

WELL-SORTED SAND

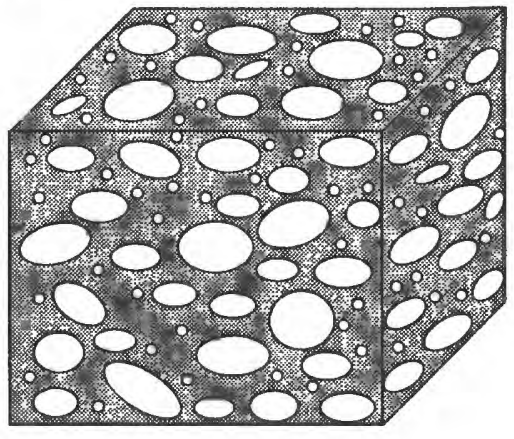

POORLY-SORTED SAND

SECONDARY OPENINGS

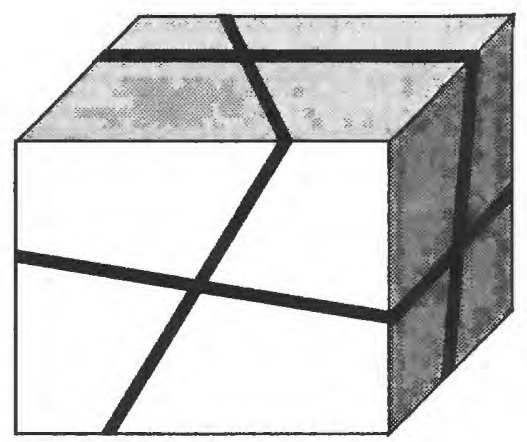

FRACTURED ROCK

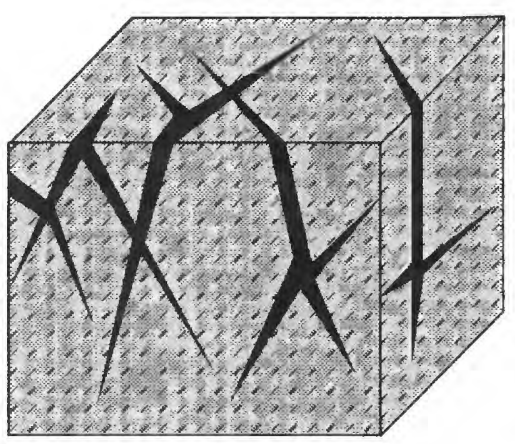

FRACTURES IN GRANITE

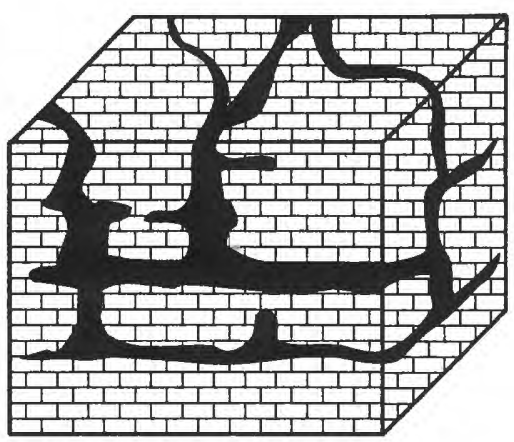

CAVERNS IN LIMESTONE

Figure 8.--How water occurs in rocks (from Heath, 1983, p. 2). 


\section{GROUND WATER--Continued}

Occurrence and Movement--Continued

Unconsolidated Deposits

\section{Flow is Entirely Within Local Systems}

Deposits underlying areas that are not irrigated and occur above stream level are dry.

Unconsolidated deposits are mapped (pl. 1) in five Quaternary map units: alluvium, which includes some areas of colluvium; terrace and pediment deposits; glacial deposits; landslide deposits; and undivided surficial deposits. Unconsolidated deposits consist of various proportions of silt, sand, gravel, cobbles, and rock fragments, and are found principally near the major streams. Lithologic descriptions of all the geologic units are given in the Supplemental Information section. The unconsolidated deposits are present in several landforms: floodplains along the streams; high terraces both near the present stream channel and farther away; thin, sloping pediment surfaces; glacial moraines; and landslide areas.

The unconsolidated deposits can contain substantial amounts of water in the primary openings between the sand, gravel, and cobbles (secondary openings cannot develop). However, most of the unconsolidated deposits are not saturated. The only unconsolidated deposits that contain substantial water are those that are recharged by irrigation or that are hydraulically connected to perennial streams. Precipitation is greatest in and near the mountains, and some unconsolidated deposits are saturated above stream level, particularly in landslide and fan deposits.

Ground-water movement in unconsolidated deposits occurs only in local systems because most of the deposits are discontinuous due to limited areas of deposition and subsequent erosion (fig. 9). The direction of flow within individual deposits is generally the same as the slope of the land surface, from higher to lower. The only unconsolidated deposits through which ground water can flow out of the county are along Clarks Fork Yellowstone River to the north and along the Shoshone and Greybull Rivers to the east.

In the major areas of irrigation where the land may become waterlogged because of poor drainage of the applied water, ground-water flow is modified by installing drains to prevent waterlogging. In 1985, 300 miles of drains was constructed by the U.S. Bureau of Reclamation in the Heart Mountain-Garland Irrigation project area (fig. 9), with additional drains constructed by the U.S. Department of Agriculture Agricultural Stabilization and Conservation Service. 


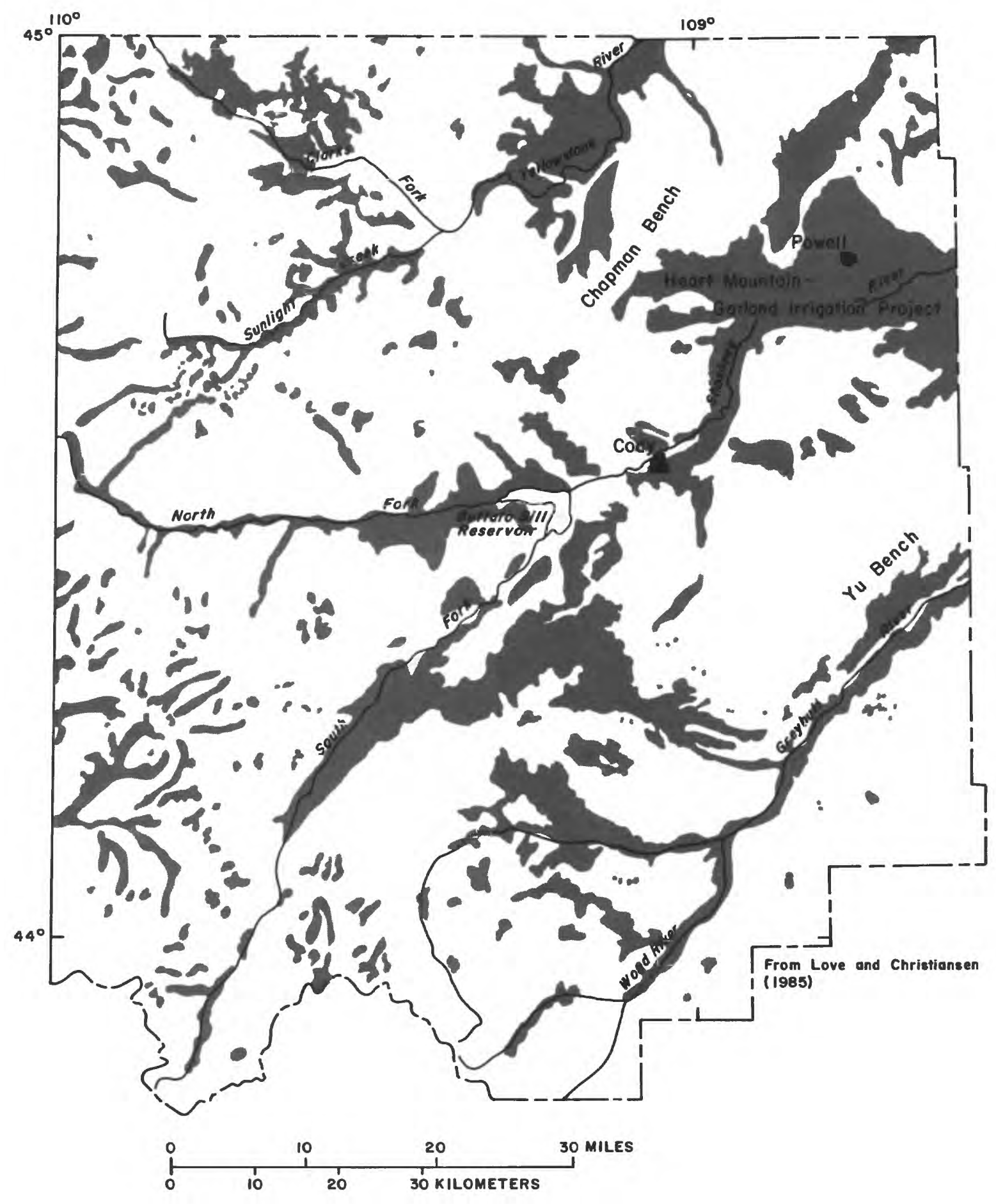

EXPLANATION

UNCONSOLIDATED DEPOSITS

Figure 9.-Generalized distribution of unconsolidated deposits. 


\title{
GROUND WATER--Continued
}

\author{
Occurrence and Movement--Continued \\ Bedrock
}

\section{Permeability of Bedrock is Both Primary and Secondary}

\author{
Some movement of water is regional, but most is local.
}

The bedrock geologic units range from volcanic rocks of Tertiary age to crystalline rocks of Precambrian age (pl. 1). Clastic rocks (siltstone, sandstone, and shale) and carbonate rocks (limestone and dolomite) also are present. Bedrock underlies the unconsolidated deposits and crops out throughout the area. The bedrock geologic units also are discontinuous, and, as in the unconsolidated deposits, occurrence and movement of water is severely restricted within the county. The description of geologic units in Park County is given in the Supplemental Information section at the end of this report.

Ground water is present in bedrock in both primary and secondary openings. The permeability of clastic deposits at the time of deposition usually is decreased by subsequent cementation and compaction, but primary permeability sufficient to yield water to wells and springs persists, particularly in the younger rocks. Permeability in intrusive igneous rocks, crystalline rocks, and carbonate rocks is secondary-the result of fracturing, weathering, and, for carbonates, solution.

The extensive shales in the county do not have substantial primary permeability, and with the exception of the Mowry Shale, they do not develop secondary permeability. The Mowry Shale is partly siliceous and brittle, and may locally develop secondary permeability instead of folding with plastic deformation like most shales.

Movement of water in bedrock flow systems in the county is both regional and local. The quantity of water flowing in local systems, however, probably exceeds that in the regional system. In the mountains where there is the largest amount of precipitation available for recharge and probably the largest amount of flow, ground-water movement is local, because the volcanic rocks in the mountains do not extend into the Bighorn Basin. Movement of water in the sedimentary rocks in the mountains also is local, because continuity with basin sedimentary rocks mostly has been interrupted by faulting. Only the crystalline rocks are continuous throughout the county; however, because these rocks have very low permeability with depth and because the resistance to flow is proportional to the length of the flow path, little water flows through them.

Regional flow in the sedimentary rocks in the basin is more likely than in the mountains, because the formations are continuous from the outcrops on the flanks of the mountains into the basin, beyond the county. The direction of regional flow in sedimentary units that do not crop out in the county probably is similar to that in the Tensleep Sandstone. The direction of flow in the Tensleep Sandstone is assumed to be perpendicular to the potentiometric contours shown in figure 10. However, outcrops of other units would impose local recharge or discharge areas in the regional flow pattern. Flow, again, would be small because of the decrease in permeability with depth and because of the length of the flow paths. Flow at De Maris Spring at the mouth of Shoshone Canyon is due partly to the inability of the Paleozoic rocks to transport all recharge water in the regional system. Because the Tertiary sedimentary rocks crop out in the northeastern part of the county, regional flow is restricted from flowing north, and, to a lesser extent, east. 


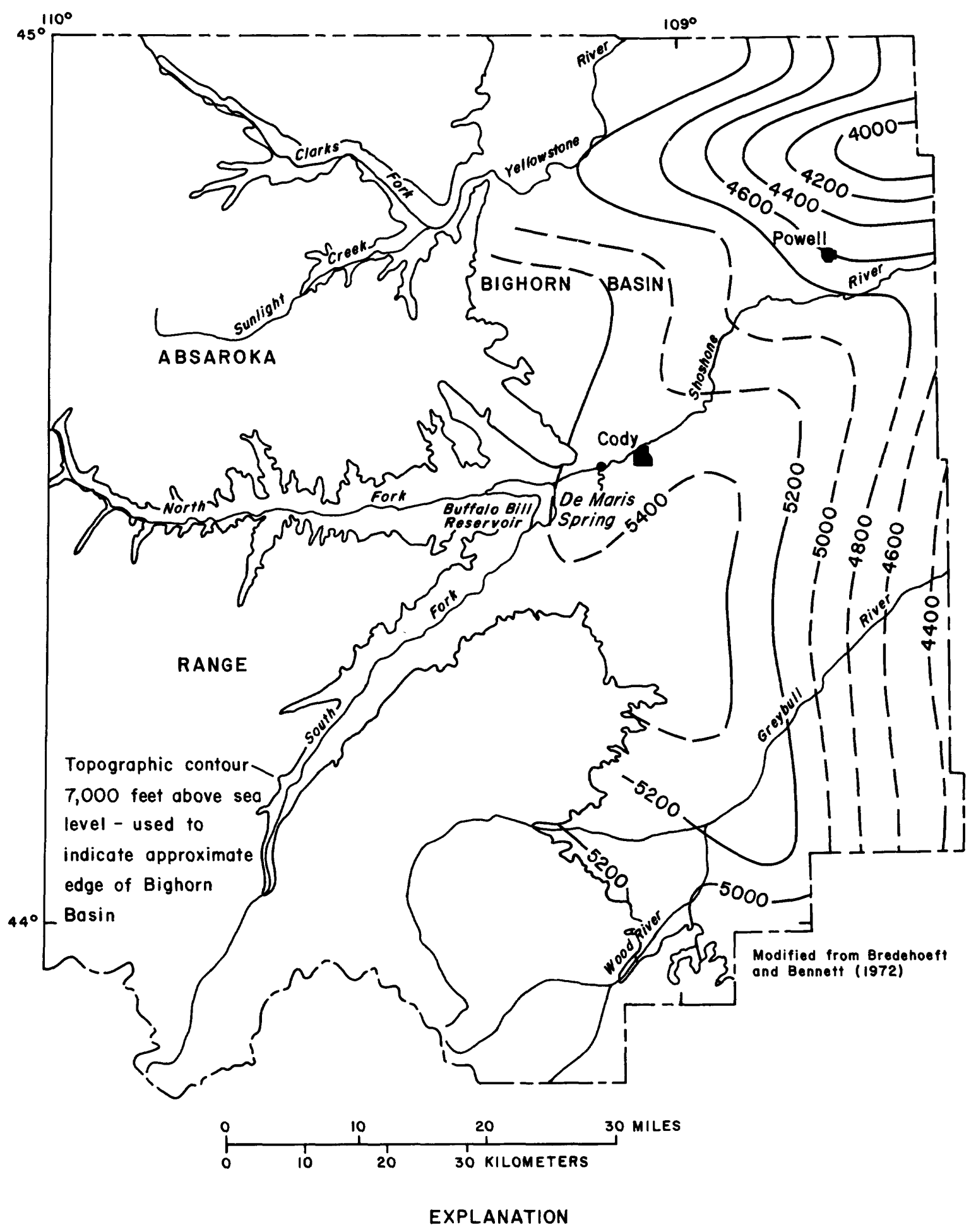

-5400- - POTENTIOMETRIC CONTOUR -- Dashed where approximately located. Contour interval 200 feet. Datum is sea level

Figure 10.-Potentiometric-surface map of the Tensleep Sandstone. 


\title{
GROUND WATER--Continued
}

\author{
Availability \\ Unconsolidated Deposits
}

\section{The Most Readily Available Water is From Alluvium and Terrace Deposits in Irrigated Areas}

\author{
Pediment deposits are too thin to yield water to wells.
}

Unconsolidated deposits present in the Bighorn Basin where there is the greatest concern for availability of water consist of alluvium, colluvium, terrace, and pediment deposits (fig. 9). The alluvium and terrace deposits, where saturated, will readily yield water to wells, but the colluvium is too poorly sorted and the pediment deposits too thin to yield substantial quantities of water to wells. Colluvium is present only in small areas and is mapped with alluvium on plate 1 . Potential availability of water for each geologic unit, along with a lithologic description and thickness of the unit, if known, is given in the Supplemental Information section.

The availability of water from the alluvium is limited by the small saturated thickness. In 1986 there were no irrigation wells producing from the alluvium. Large yields can be obtained, however, by using collection galleries rather than conventional wells. The municipal ground-water supply for the town of Powell in 1986 was from collection galleries that yielded in excess of 1,000 gallons per minute.

The terrace deposits in the basin are not usually saturated. The availability of water from terrace deposits is dependent on recharge from the application of water for irrigation on the terrace. Terrace deposits capping Y U, Polecat, and Chapman Benches are not irrigated and do not have sufficient saturated alluvium to furnish adequate water for either stock or domestic use (fig. 9).

The trend toward urban development of irrigated lands will decrease the amount of irrigation. Recharge to the alluvium may not be adequate to sustain water supplies to individual wells completed in the terrace deposits where a large percentage of a terrace has been taken out of irrigation. An alternative source of water may be necessary during winter months and possibly year-round.

Pediment deposits are mapped with terrace deposits on plate 1. However, the difference in the availability of water between the pediment and terrace deposits is shown by the sources of domestic supply north and south of Bitter Creek (north of Powell). South of Bitter Creek, suitable domestic supplies can be obtained from individual wells completed in the terrace deposits. North of Bitter Creek is a pediment deposit which cannot provide suitable domestic supplies. The domestic supplies are furnished by a water company from wells completed in the terrace deposit south of the creek. 


\title{
GROUND WATER--Continued
}

\author{
Availability--Continued \\ Bedrock
}

\section{Ground Water not Readily Available From Bedrock}

In areas where shale is the shallowest bedrock, ground water is not available at shallow depths

Water is not readily available from bedrock at shallow depths in many areas, particularly where the following conditions exist: (1) thick shales are exposed at the surface; (2) drilling depths are excessive because of folding and faulting; or (3) the dominant lithology is fine-grained material, with coarse-grained material occurring only in lenses. Potential availability of water for each geologic unit in the county is given in the Supplemental Information section.

Several geologic units near the surface are dominantly shale. Where these units crop out or where water supplies cannot be obtained from overlying, unconsolidated deposits, generally it is necessary to drill into the units underlying the shale. The thickness of a geologic unit listed in the Supplemental Information section approximates the depth of a well needed to penetrate the full thickness where the unit is horizontal. The Cody Shale, for example, crops out near the mountains (fig. 11) and is as much as 3,000 feet thick. Some users in the outcrop area of the Cody Shale haul or pipe their water to the point of use rather than drilling a deep well.

Folding and faulting of geologic units have been extensive, particularly near the mountains, and these are factors in selecting locations for wells. For example, the Tensleep Sandstone is a dependable source of water in many areas-yields to wells may be as much as 50 gallons per minute. Although the Tensleep Sandstone crops out along the east flank of the mountains, the axis of the structural basin is nearby, along the west side of the Bighorn Basin, and within 10 miles east of the outcrop the Tensleep Sandstone may be 5,000 feet below land surface. The steeper the inclination of a formation, the greater the depth of drilling to penetrate the entire thickness.

Faulting increases the permeability of competent rocks, but also can change the normal sequence of rocks expected in drilling. As shown in the cross section in figure 12 , faulting has changed the expected sequence of the geologic formations encountered when drilling well A. Where the Cody Shale is near the surface, well B could be drilled about 600 feet deep to rocks other than the Cody Shale, but well $\mathrm{C}$ would penetrate 3,000 feet of Cody Shale before encountering other rocks. Detailed geologic quadrangle maps by Pierce $(1948,1965,1966,1970$, and 1978) and by Pierce and Nelson $(1968,1969$, and 1971) could be used for siting wells where more detail is required in areas of small outcrops or extensive folding and faulting as shown on plate 1 .

Several geologic units described in the Supplemental Information section contain sandstone that will yield water to wells, but the sandstone is lenticular and discontinuous, and the depth necessary to obtain even small water supplies needed for stock or domestic use cannot be predicted. The Willwood and Fort Union Formations are exposed at the surface or underlie unconsolidated deposits in most of the basin but they are not reliable sources of water. Many wells in use are less than 200 feet deep, but wells as deep as 600 feet have not yielded enough water for livestock. The best chances for obtaining water from the Fort Union Formation are along the western edge of the outcrops shown on plate 1 , where sandstone and conglomerate are prevalent.

Yields of 1,000 gallons per minute may be possible because of the large thickness of sandstone in the Lance, Meeteetse, and Mesaverde Formations. In other counties in Wyoming the Tensleep Sandstone has a known well yield of 300 gallons per minute, and flowing wells in the Madison Limestone and other paleozoic formations are known to have yields in excess of 1,000 gallons per minute (Cooley, 1986). 


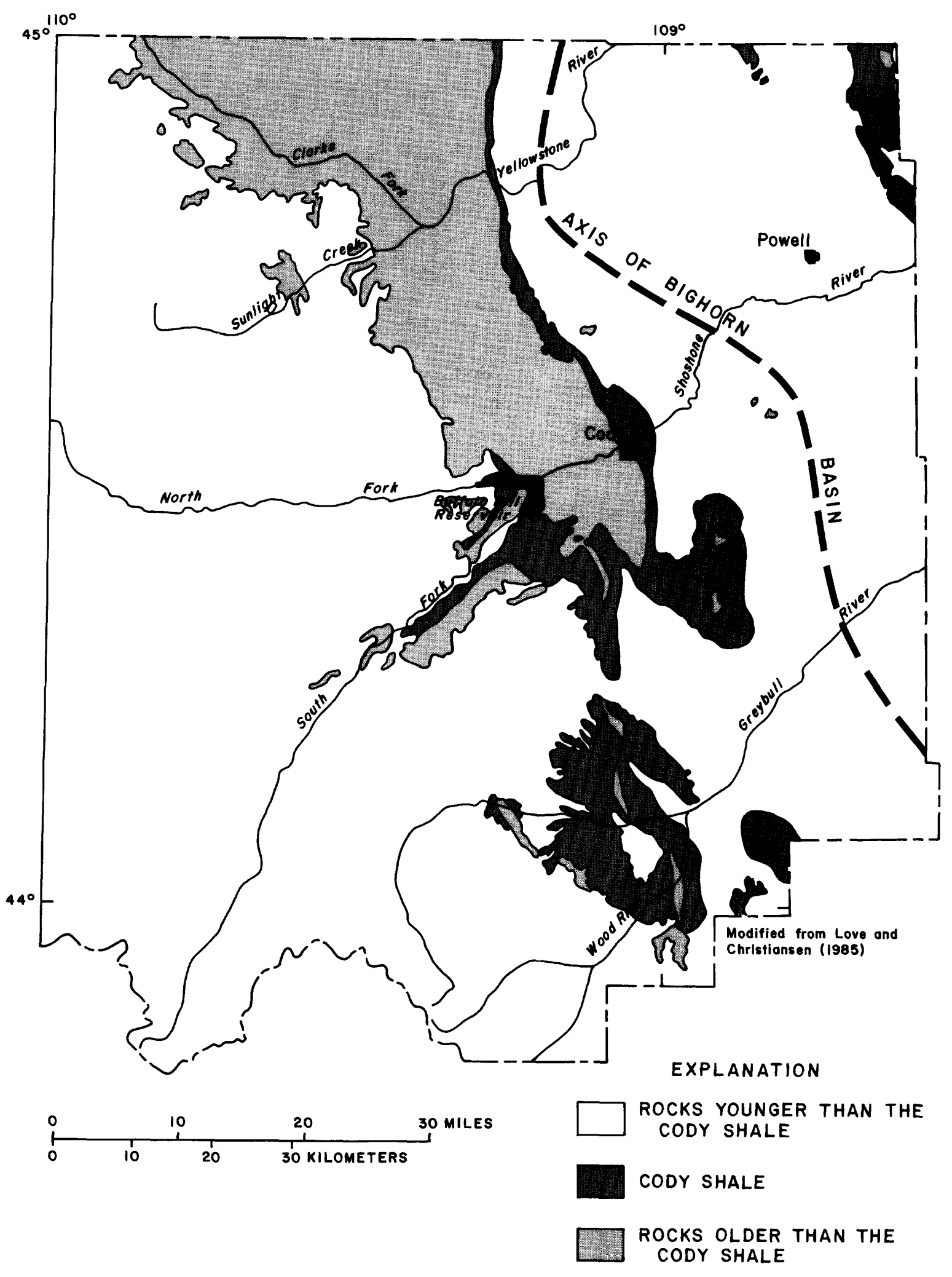

Figure 11.--Generalized distribution of bedrock. 


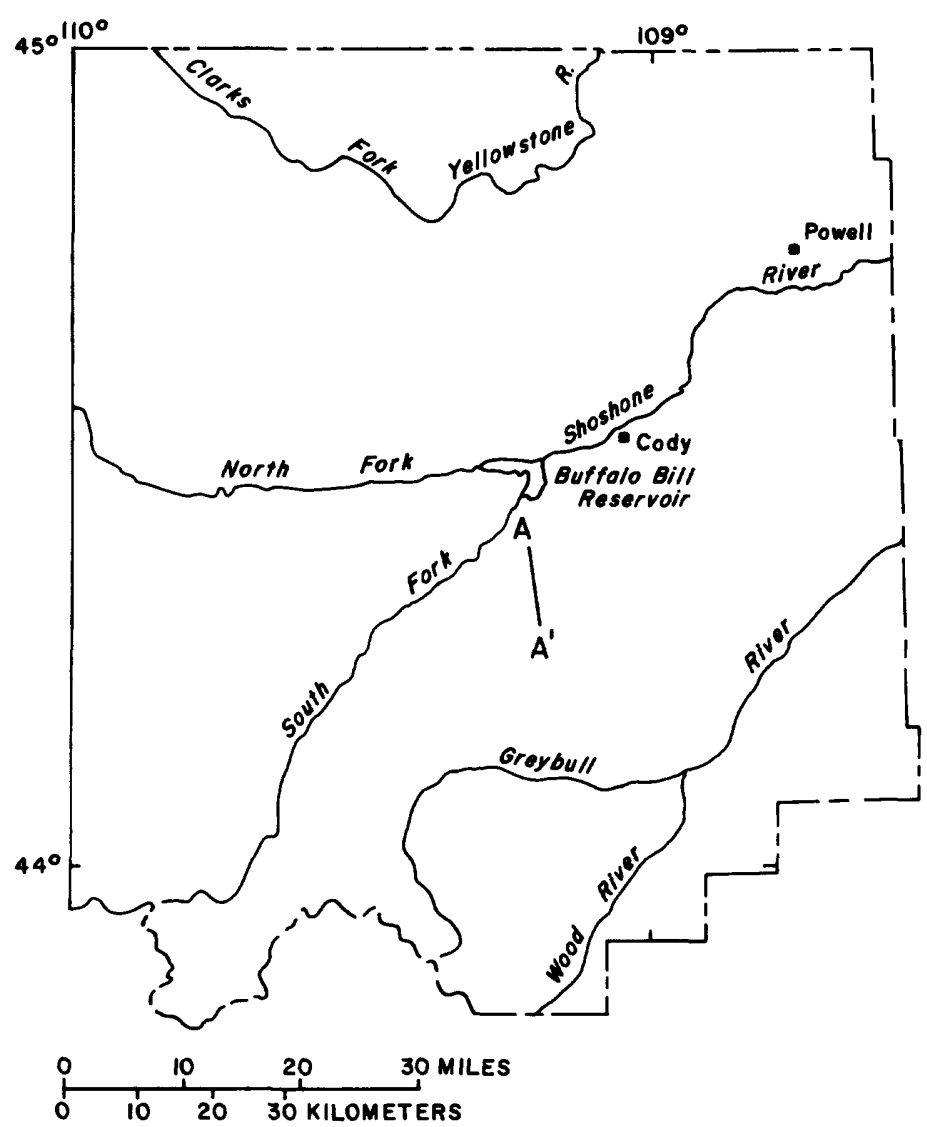

A

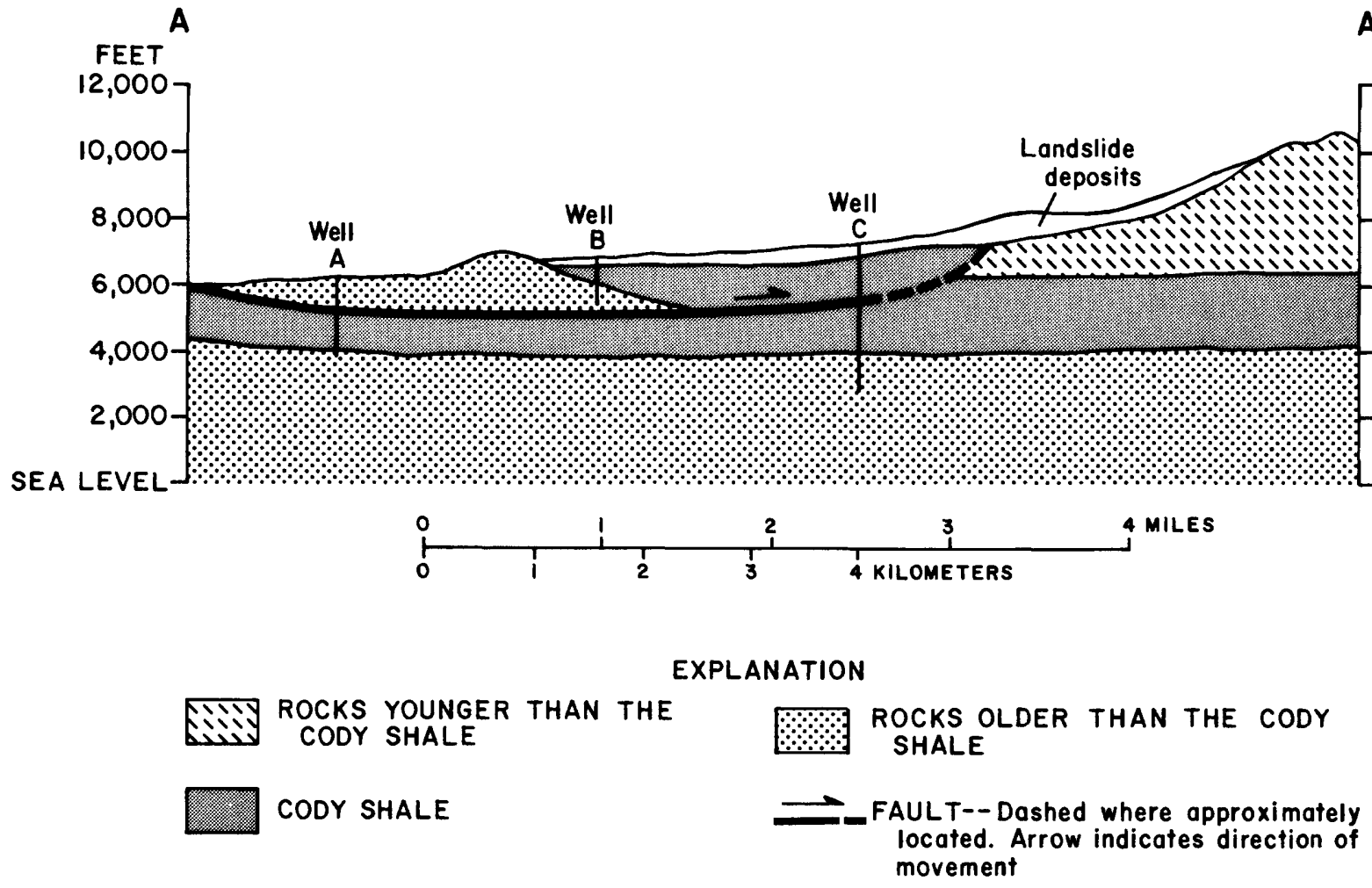

$A^{\prime}$

FEET

$-12,000$

10,000

8,000 movement

Figure 12.--Generalized section $A-A^{\prime}$ showing faulting (modified from Pierce, 1970). 


\section{SURFACE WATER}

Surface-Water Data

\section{Information Available From 49 Sites in and Adjacent to Park County}

Data include stage, discharge, and chemical and physical properties of water.

Discharge measurements or water-quality samples, or both, are collected on a systematic basis by the U.S. Geological Survey at 49 surface-water sites in and adjacent to Park County (fig. 13). For this report, site numbers are assigned instead of the eight-digit downstream-order station identification numbers that customarily are used by the U.S. Geological Survey. Site numbers and corresponding eight-digit station numbers, descriptions of locations, and type and period of record for each station are listed in the Index of Surface-Water Sites and Stations in the Supplemental Information section at the back of this report. As indicated by the periods of records, some stations listed are still in operation, but many have been discontinued.

Data on the quantity of surface water are collected at continuous-streamflow or peak-flow sites. Data collected at a continuous-streamflow site include stage (water level in the stream) and periodic discharge measurement. Streamflow data for daily or other periods of flow, are computed from the relation between the stage of the river and the discharge, measured at various stages. At peak-flow sites, only the peak stage is recorded, and the peak flow generally is computed by indirect methods rather than by making actual measurements of discharge. Peak-flow information commonly is used for design of structures, such as bridges and culverts.

Data on the chemical and physical properties of water usually are collected at the time of a discharge measurement. The data most commonly collected are specific conductance, $\mathrm{pH}$, temperature, and concentrations of principal ions dissolved in the water. Traceelement, radiochemical, biological, sediment, pesticide data, and daily measurements of temperature and specific conductance are available for some stations.

Data for surface-water sites shown in figure 13 are published in the U.S. Geological Survey Water-Data Report series and can be retrieved from computer files. The data are compiled by water year, which is October 1 through September 30. 


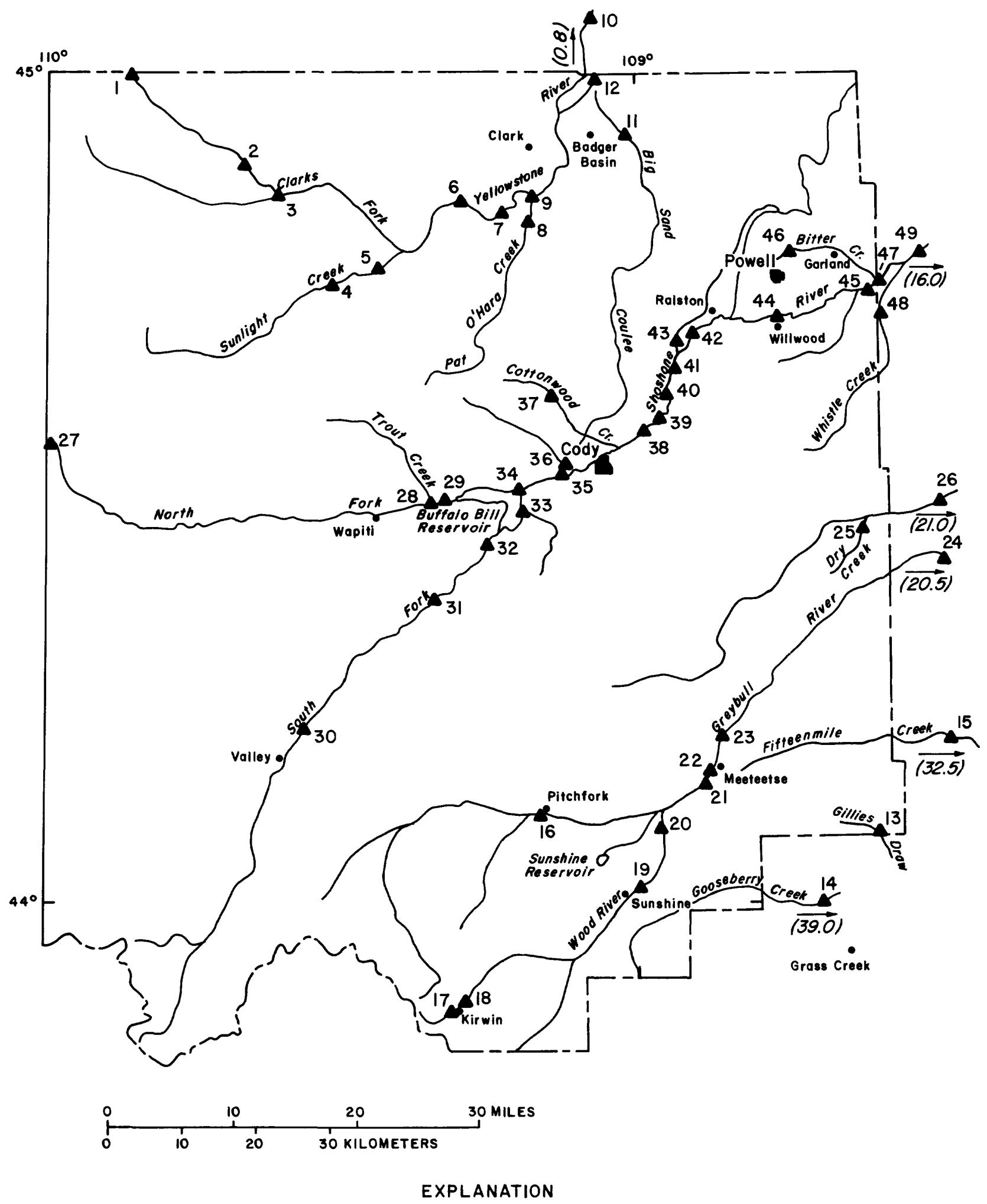

22 SITE AND NUMBER

(39.0) APPROXIMATE DISTANCE TO STATION

FROM COUNTY LINE, IN MILES

Figure 13.--Location of surface-water data-collection sites. Stations at some sites have been discontinued (see periods of record in Supplemental Information at back of report). 


\title{
SURFACE WATER--Continued
}

\author{
Streamflow Characteristics
}

\section{The Source of Perennial Flow is Mountain Precipitation}

\author{
Flow characteristics of perennial streams in Bighorn Basin show the \\ effects of surface-water development.
}

Flow-duration curves, computed from streamflow data, show the percentage of time during the period of record that specified daily mean discharges were equaled or exceeded. The flow-duration curves in figure 14 show the difference in characteristics of flow between streams that originate in the mountains and streams that originate at lower altitudes in badlands and plains.

The curve for South Fork Shoshone River near Valley (site 30) has a relatively flat slope, indicating the storage of water in the drainage basin (snowpack and ground water) that tends to equalize and sustain flow throughout the year. Daily mean discharge at site 30 exceeded 55 cubic feet per second for 99 percent of the period of record. Large amounts of snow persist in the mountains late into summer, contributing to the flow in streams that originate in the mountains, but snowmelt contributes to flow in streams that originate at lower altitudes only through early spring because of the difference in climate in the two areas.

The curve for Fifteenmile Creek near Worland (site 14) is relatively steep, indicating no storage in the drainage basin to sustain flow throughout the year. Fifteenmile Creek flows less than 25 percent of the time, and all the flow is from direct runoff of rainfall and snowmelt.

Flow characteristics changed at two streamflowgaging sites following construction of a reservoir. These changes are indicated by flow-duration curves for Wood River at Sunshine (site 19) and Greybull River at Meeteetse (site 22) for 10-year periods before and after construction of Sunshine Reservoir (fig. 15). Since 1974, water has been diverted from the Wood River upstream from the streamflow-gaging site into the off-stream reservoir. Comparison of the curve for 1974-84 with the curve for an earlier 10-year period before construction of the reservoir (1962-72) shows a lower discharge for a given percentage of time after the reservoir began operation. At high flow, the discharge after water diversion to the reservoir was about 3,000 cubic feet per second less during 1974-84 than before water diversion to the reservoir. At low flow, discharge was greater than 10 cubic feet per second 99 percent of the time after water diversion to the reservoir, but greater than 100 cubic feet per second 99 percent of the time before water diversion.

Flow-duration curves based only on July-August data for Greybull River at Meeteetse (site 22, fig. 15) indicated the effects of diversions from the Wood River and releases from Sunshine Reservoir. Discharges greater than 1,000 cubic feet per second during JulyAugust occurred less frequently during 1974-84 than before the diversions (1962-72). In contrast, releases from the reservoir have increased the frequency of occurrences of July-August discharges smaller than 1,000 cubic feet per second. Low flow during 1974-84 increased about 100 cubic feet per second because of the release of water from the reservoir for irrigation.

The flow characteristics for streams in Park County, and adjoining areas in Wyoming in the Missouri River drainage basin, are summarized by Peterson (1988). 


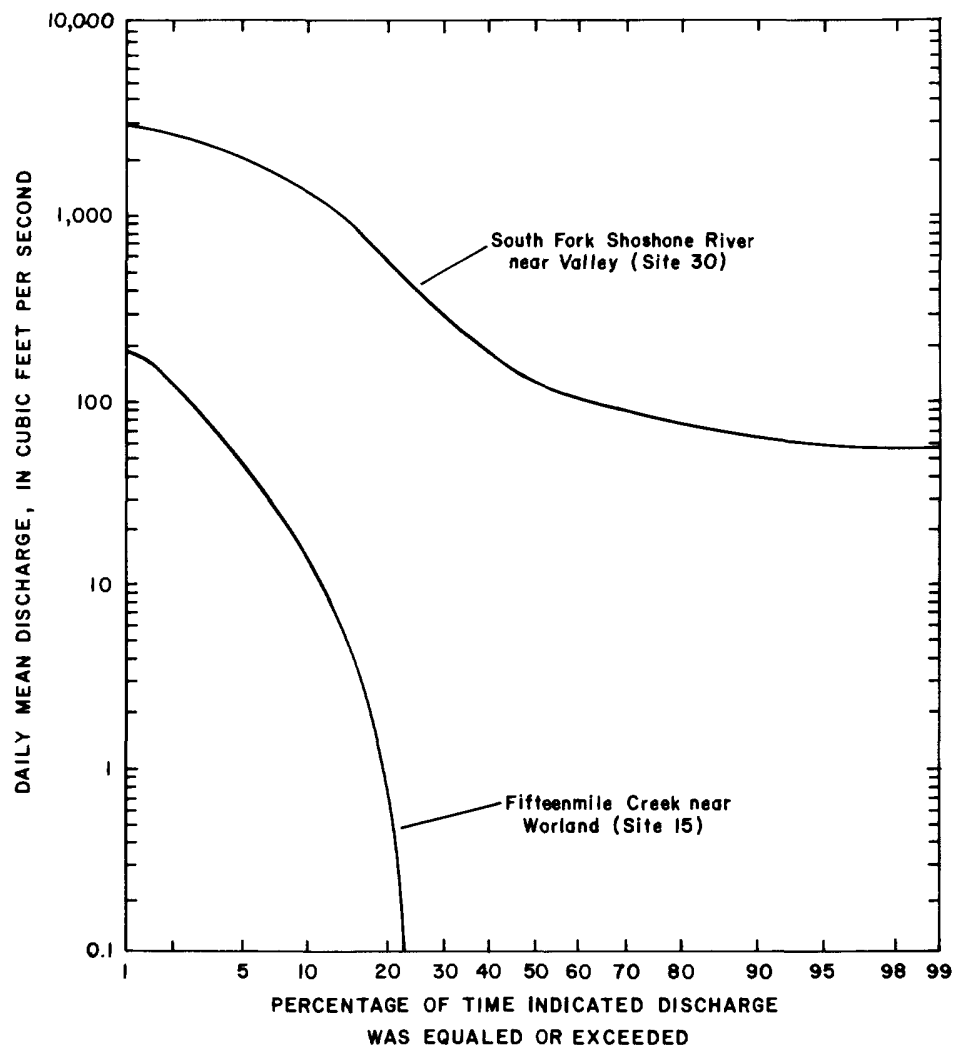

Figure 14.-Flow-duration curves for South Fork Shoshone River near Valley and Fifteenmile Creek near Worland.

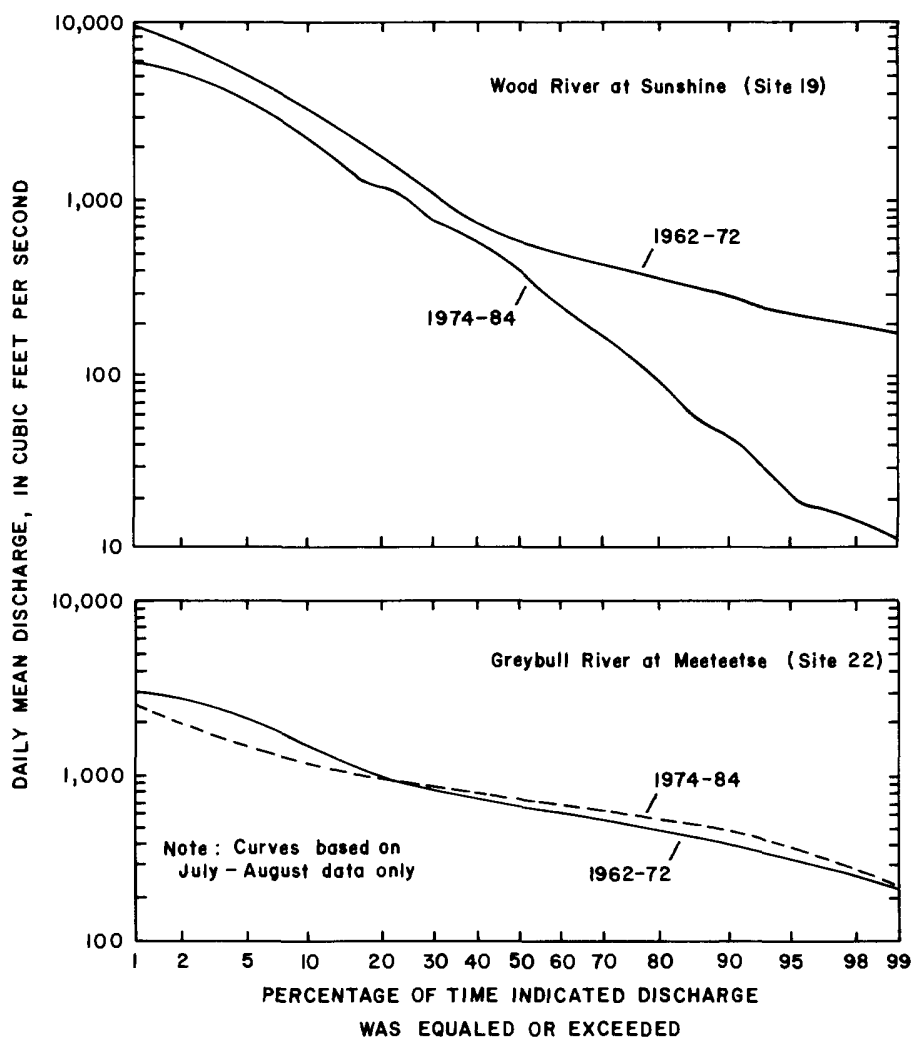

Figure 15.--Flow-duration curves for Wood River at Sunshine and Greybull River at Meeteetse. 


\title{
SURFACE WATER--Continued \\ Streamflow Characteristics--Continued \\ Average Flow
}

\section{Streams Originating in the Mountains Have the Largest Average Flow}

\author{
Average annual flow is as much as 598 acre-feet per square mile from the mountains \\ and as little as 14.8 acre-feet per square mile from badlands and plains.
}

The average annual runoff from streams originating in the mountains is as much as 598 acre-feet per square mile-the runoff calculated for site 10, Clarks Fork Yellowstone River near Belfry, Mont. (fig. 16). In contrast, the average annual runoff for streams originating in badlands and plains is as small as 14.8 acrefeet per square mile - the value calculated for site 15 , Fifteenmile Creek near Worland.

The differences in contribution to streamflow by runoff from mountain areas and from badlands and plains and the effects of development of water for irrigation on average flow are shown by flow in the Greybull River. The uppermost station in the drainage basin is Wood River at Sunshine (fig. 16, site 19), where the average annual runoff is 437 acre-feet per square mile and the average annual discharge is 117 cubic feet per second. The next station downstream is Greybull River at Meeteetse (fig. 16, site 22). The average annual runoff decreases to 359 acre-feet per square mile because the ratio of mountain area to badlands and plains area is smaller and the proportion of irrigated area is greater. However, the average annual discharge increases to 347 cubic feet per second, because the drainage area is greater. The next station downstream on the Greybull River is 20.5 river miles east of the county (fig. 16, site 24). At this site both the average annual runoff and the average annual discharge are smaller than at upstream stations.

The difference in average annual runoff between sites 22 and 24 minus the average annual runoff in Dry Creek at Greybull (fig. 16, site 26) is the approximate consumptive use of water in the reach between sites 22 and 24. Flow in Dry Creek is sustained by return flow of irrigation water diverted from the Greybull River. This difference is 203.7 acre feet per square mile, or about 56 percent of the runoff at Meeteetse.

Estimates of the natural, average flow of streams at ungaged sites can be made using equations developed by Lowham (1988) that relate climatic factors and physical characteristics of the drainage basin. The size of the drainage area is the most important physical characteristic used in estimating flows at ungaged sites 


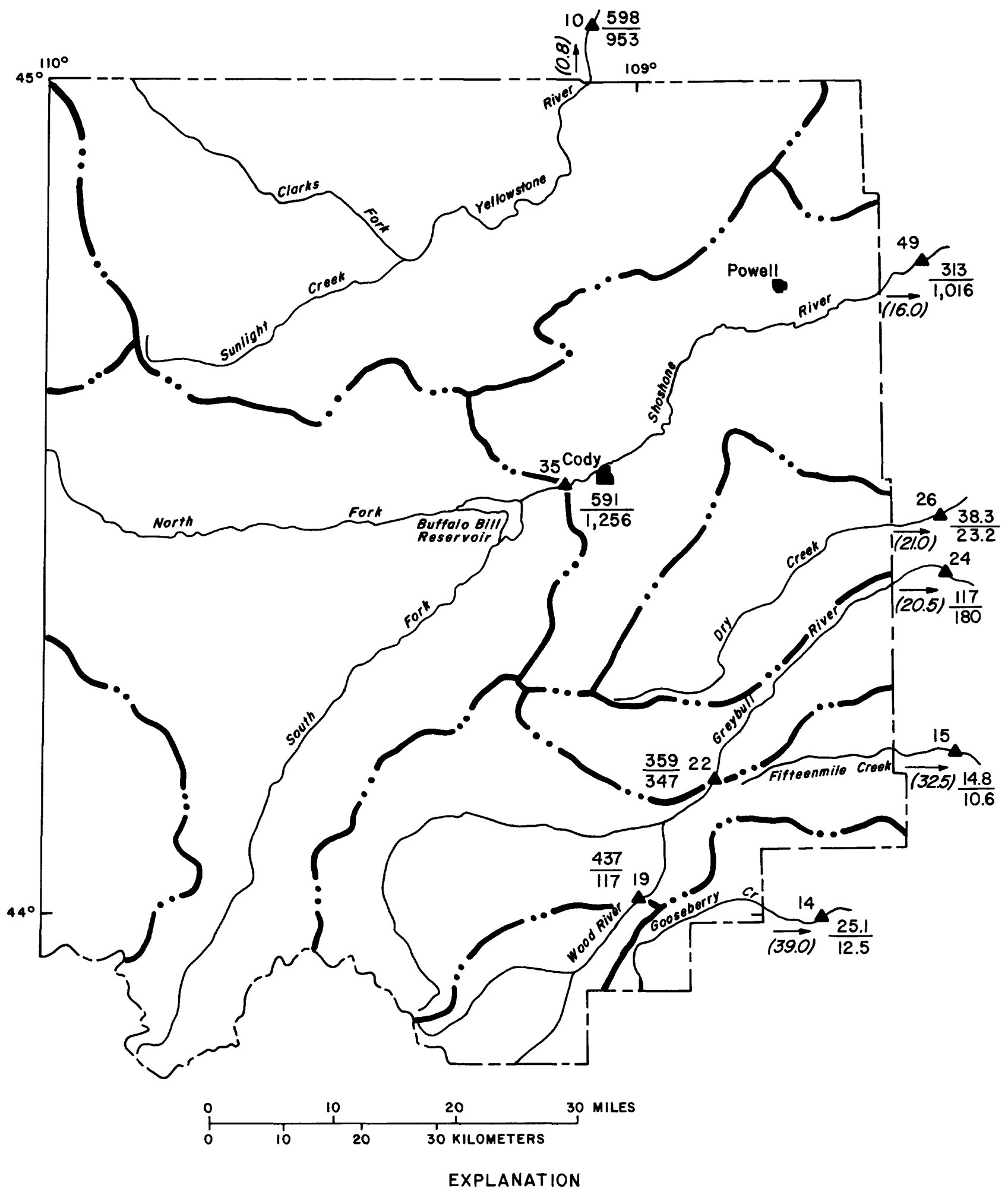

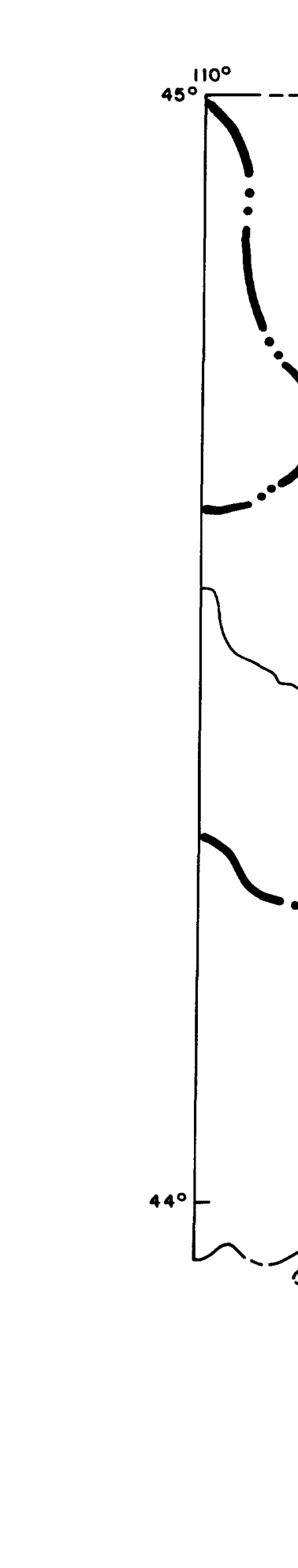

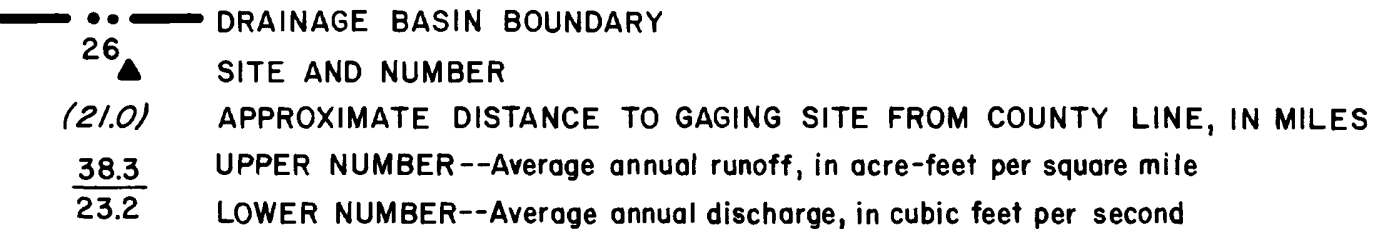

Figure 16.-Average annual runoff and discharge for selected sites. 


\section{SURFACE WATER--Continued}

Streamflow Characteristics--Continued

Low Flow

\section{Natural Low Flow is Sustained by Ground Water or Melting Snow}

Development of water for irrigation has changed the low-flow characteristics of some streams.

Major streams originating in the mountains have sustained flow between periods of precipitation because of melting snow from the near-permanent snowpack and because of ground-water discharge. Streams that originate in badlands and plains and do not receive return flow from irrigation have long periods of no flow.

Low flow of some streams changed as a result of developing the water for irrigation. Low flow of the Wood River at Sunshine (site 19) decreased and low flow of the Greybull River at Meeteetse (site 22) increased because of operation of a reservoir constructed for irrigation (fig. 15). In addition, perennial flow in Bitter Creek (northeastern Park County) is due primarily to return flow from irrigation.
Streamflow data were analyzed for 7-day lowflow statistics. The results of these analyses are listed in table 1 , and the location of the sites is shown in figure 13. At site 4, the flow during 7 consecutive days is 16 cubic feet per second or less for a 2-year recurrence interval, 14 cubic feet per second or less for a 5 -year recurrence interval, and 13 cubic feet per second or less for 10- and 20-year recurrence intervals. Lowflow statistics for perennial streams provide useful information for water supplies, instream fisheries, and waste dilution. Because low flow in ephemeral streams is zero (no flow) the 7-day low-flow statistics are of little value. However, the stations can be used to estimate the dependable quantity of water that can be developed by use of a reservoir-storage frequency model developed by Glover (1984). 
Table 1. Seven-day low-flow data for selected sites

[Flow is in cubic feet per second; --, no data]

\begin{tabular}{ccccc}
\hline $\begin{array}{c}\text { Site number } \\
\text { (fig. 13) }\end{array}$ & $\mathbf{5}$ & \multicolumn{4}{c}{ Recurrence interval, in years } \\
\cline { 2 - 5 } & $\mathbf{2}$ & $\mathbf{5}$ & $\mathbf{1 0}$ & $\mathbf{2 0}$ \\
\hline 4 & 16 & 14 & 13 & 13 \\
16 & 18 & 14 & 12 & 9.9 \\
19 & 15 & 5.9 & 3.2 & 1.8 \\
20 & 32 & 22 & 17 & 13 \\
22 & 47 & 36 & 30 & 26 \\
29 & 131 & 114 & -- & -- \\
30 & 58 & 51 & 48 & 45 \\
32 & 11 & 5.9 & 4.5 & 3.6 \\
35 & 288 & 179 & 135 & 105 \\
39 & 394 & 284 & 237 & \\
45 & 47 & 19 & 12 & 8.2 \\
\hline
\end{tabular}




\section{SURFACE WATER--Continued}

Streamflow Characteristics--Continued

Floods

\section{0-Year Flood Data Available for Seven Streamflow Sites \\ Most floods are caused by large discharges; however, some flooding occurs because of ice buildup in streams.}

Seven streamflow-gaging sites in Park County have discharge records of sufficient length to estimate a 100-year flood. The sites and the 100-year flood are shown in figure 17. A 100-year flood is defined as the annual maximum instantaneous discharge that will be equalled or exceeded on the average of once in 100 years. Expressed another way, there is a 1-percent chance that the 100 -year flood will occur in any year. The 100-year flood at an ungaged site can be estimated by using methods developed by Lowham (1988).

Streams that originate in the mountains generally flood during the spring or early summer. The magnitude of the flood depends on the volume and water content of the snow that has accumulated during the preceding winter, air temperature, solar radiation, and the amount of spring rain. A slow warming trend in the spring at high elevations causes a prolonged runoff with flow remaining in the stream channel. An early warm spell at a low elevation, however, can cause water to overflow the banks onto the floodplain. Floods result from a combination of deep snowpack, warm air, and either saturated or frozen ground. Flooding in May 1978 , which resulted from these conditions with saturated ground, was described by Parrett and others (1984).

Flooding can occur even during periods of small discharge because of ice dams at bridges during spring thaw or from buildup of ice during cold periods that result in flow over the top of the ice. In 1984, severe ice buildup resulted in flooding of the Shoshone River just east of the county and minor flooding within the county. 


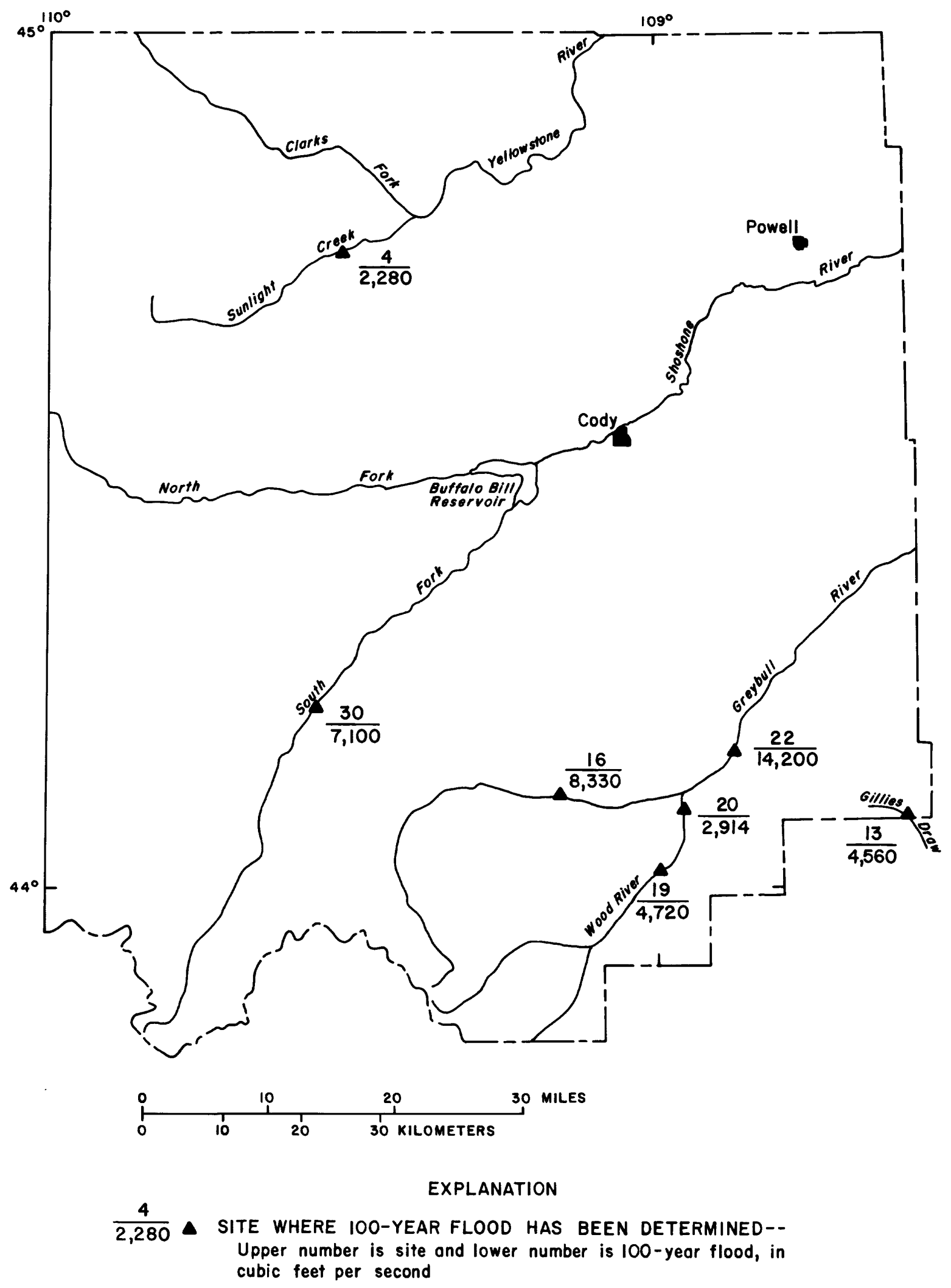

Figure 17.-Location of sites where 100-year flood has been determined. 


\section{CHEMICAL QUALITY OF WATER}

Relation Between Chemical Quality and Use

Domestic Use

\section{Regulations are Legally Enforceable if a Health Hazard is Present}

Nonenforceable regulations are based on aesthetics and corrosion prevention.

The U.S. Environmental Protection Agency, as part of the Safe Drinking Water Act (Public Law 93-523), has established primary and secondary drinking-water regulations for public water supplies (U.S. Environmental Protection Agency, 1989a; 1989b). These regulations are summarized for selected constituents in table 2. Primary drinking-water regulations are based on maximum contaminant levels, which are legally enforceable because prolonged drinking of the water would be a health hazard. The secondary drinking-water regulations are based on secondary maximum contaminant levels, which are nonenforceable, and include factors such as aesthetic properties and corrosion potential of water. 
Table 2. Drinking-water regulations for public water supplies for selected constituents

[Regulations are from U.S. Environmental Protection Agency, 1989a, 1989b; --, no regulation determined; $\mathrm{PCU}$, platinum-cobalt unit; $\mathrm{mg} / \mathrm{L}$, milligram per liter; $\mu \mathrm{g} / \mathrm{L}$, micrograms per liter; $\mathrm{pCi} / \mathrm{L}$, picocuries per liter; mL, milliliter]

\begin{tabular}{|c|c|c|}
\hline Property or constituent & $\begin{array}{c}\text { Maximum } \\
\text { contaminant level }\end{array}$ & $\begin{array}{c}\text { Secondary } \\
\text { maximum } \\
\text { contaminant level }\end{array}$ \\
\hline \multicolumn{3}{|l|}{ Properties } \\
\hline $\mathrm{pH}$ & -- & $6.5-8.5$ \\
\hline Color, PCU & -- & 15 \\
\hline Dissolved solids, $\mathrm{mg} / \mathrm{L}$ & -- & 500 \\
\hline \multicolumn{3}{|l|}{ Major ions, mg/L } \\
\hline Sodium & -- & $(1)$ \\
\hline Sulfate & -- & 250 \\
\hline Chloride & -- & 250 \\
\hline Fluoride & ${ }^{2} 4$ & 2 \\
\hline Nitrate as nitrogen, $\mathrm{mg} / \mathrm{L}$ & 10 & -- \\
\hline \multicolumn{3}{|l|}{ Trace elements, $\mu \mathrm{g} / \mathrm{L}$} \\
\hline Arsenic & 50 & -- \\
\hline Barium & 1,000 & -. \\
\hline Cadmium & 10 & -- \\
\hline Chromium & 50 & -- \\
\hline Copper & -- & 1,000 \\
\hline Manganese & -- & 50 \\
\hline Mercury & 2 & -- \\
\hline Silver & 50 & -- \\
\hline Zinc & -- & 5,000 \\
\hline \multicolumn{3}{|l|}{ Radiation and radionuclides, $\mathrm{pCi} / \mathrm{L}$} \\
\hline Gross alpha, as uranium natural & - & ${ }^{3} 15$ \\
\hline Radium-226 and radium 228 & 5 & -- \\
\hline \multicolumn{3}{|l|}{ Organic compounds, $\mu \mathrm{g} / \mathrm{L}$} \\
\hline \multicolumn{3}{|l|}{ Herbicides } \\
\hline 2,4-D & 100 & -- \\
\hline $2,4,5-\mathrm{T}$ & 10 & -- \\
\hline \multicolumn{3}{|l|}{ Insecticides } \\
\hline Endrin & .2 & -- \\
\hline Lindane & 4 & -- \\
\hline Methoxychlor & 100 & -- \\
\hline Coliform bacteria, colonies per $100 \mathrm{~mL}$ & 1 & $\left({ }^{4}\right)$ \\
\hline
\end{tabular}

${ }^{1}$ Monitoring is recommended.

${ }^{2}$ Fluoride should not exceed $4.0 \mathrm{mg} / \mathrm{L}$ in drinking water. Fluoride in children's drinking water at levels of about $1 \mathrm{mg} / \mathrm{L}$ reduces the number of dental cavities. However, some children exposed to concentrations of fluoride greater than about $2.0 \mathrm{mg} / \mathrm{L}$ may develop dental fluorosis, which in its moderate and severe forms is a brown staining or pitting of the permanent teeth.

${ }^{3}$ No regulation has been set.

${ }^{4}$ The regulation is a monthly arithmetic mean. A concentration of 4 colonies per $100 \mathrm{~mL}$ is allowed in one sample per month if less than 20 samples are analyzed or 20 percent of the samples per month if more than 20 samples are analyzed. 


\title{
CHEMICAL QUALITY OF WATER--Continued
}

\author{
Relation Between Chemical Quality and Use--Continued \\ Agricultural and Industrial Use
}

\section{Guidelines Proposed for Agricultural and Industrial Use}

\author{
The two main criteria affecting suitability of water for irrigation are dissolved-solids \\ concentration and sodium-adsorption ratio.
}

Guidelines for the chemical suitability of water for agricultural use were proposed by the National Academy of Sciences and National Academy of Engineering (1973), by the U.S. Salinity Laboratory (1954), and by Eaton (1950). The following discussion has been drawn from these reports.

Although many chemical constituents or properties of water affect its suitability for irrigation, the two main criteria are concentration of dissolved solids and the ratio of concentration of sodium to the combined concentration of calcium and magnesium, which is called the sodium-adsorption ratio (SAR). In practice, specific conductance rather than dissolved-solids concentration is commonly used as the criterion because the two are closely related and specific conductance is more easily measured.

The SAR indicates the tendency of sodium to replace adsorbed calcium and magnesium. A large SAR indicates a hazard of sodium replacing calcium and magnesium (Hem, 1985, p. 161). This replacement can damage the soil and soil structure, causing deflocculation and the soil to become impermeable to water (Hem, 1985, p. 216).

A plot of data for water samples from selected wells in Park County indicates the suitability of water from various aquifers for irrigation (fig. 18). The salinity hazard is classified $\mathrm{C} 1$ (low) through $\mathrm{C} 4$ (very high) on the basis of the specific conductance. The sodium hazard is classified S1 (low) through S4 (very high) on the basis of the SAR. The two factors are combined to classify the suitability of water for irrigation.

Plants differ widely with respect to their tolerance to dissolved minerals. The osmotic potential induced by high salinity in the soil-water solution can curtail water uptake by plants. Prolonged agricultural use of saline water is practical only where enough irrigation water can be applied to leach salts to below the root zone. Irrigation water that has a large SAR tends to destroy soil structure, especially in soils containing swelling clays. The emergence of germinating seedlings can be impeded when a soil that has been greatly affected by sodium dries and forms a hard-soil crust.

Stock can maintain good health after drinking water considered unfit for human consumption; however, large dissolved-solids concentrations can cause poor growth, sickness, and death. The National Academy of Sciences and National Academy of Engineering (1973) have suggested the following dissolvedsolids concentrations as standards for livestock use:

\begin{tabular}{cl}
\hline $\begin{array}{c}\text { Concentration } \\
\text { (milligrams per liter) }\end{array}$ & \multicolumn{1}{c}{ Rating } \\
\hline $0-999$ & Excellent \\
$1,000-2,999$ & Very satisfactory \\
$3,000-4,999$ & $\begin{array}{c}\text { Satisfactory for animals accustomed } \\
\text { to such water }\end{array}$ \\
$5,000-6,999$ & $\begin{array}{c}\text { Reasonably safe except for pregnant } \\
\text { and lactating animals }\end{array}$ \\
$7,000-10,000$ & $\begin{array}{c}\text { Unfit or usable only with consider- } \\
\text { able risk }\end{array}$ \\
\hline
\end{tabular}

The water-quality requirements of industry depend on the specific use of the water. Reports by Moore (1940) and by McKee and Wolf (1971) contain information on industrial water quality. Generally, water that has a small dissolved-solids concentration and low hardness, and does not vary greatly in quality or temperature, meets the requirements of industry. 


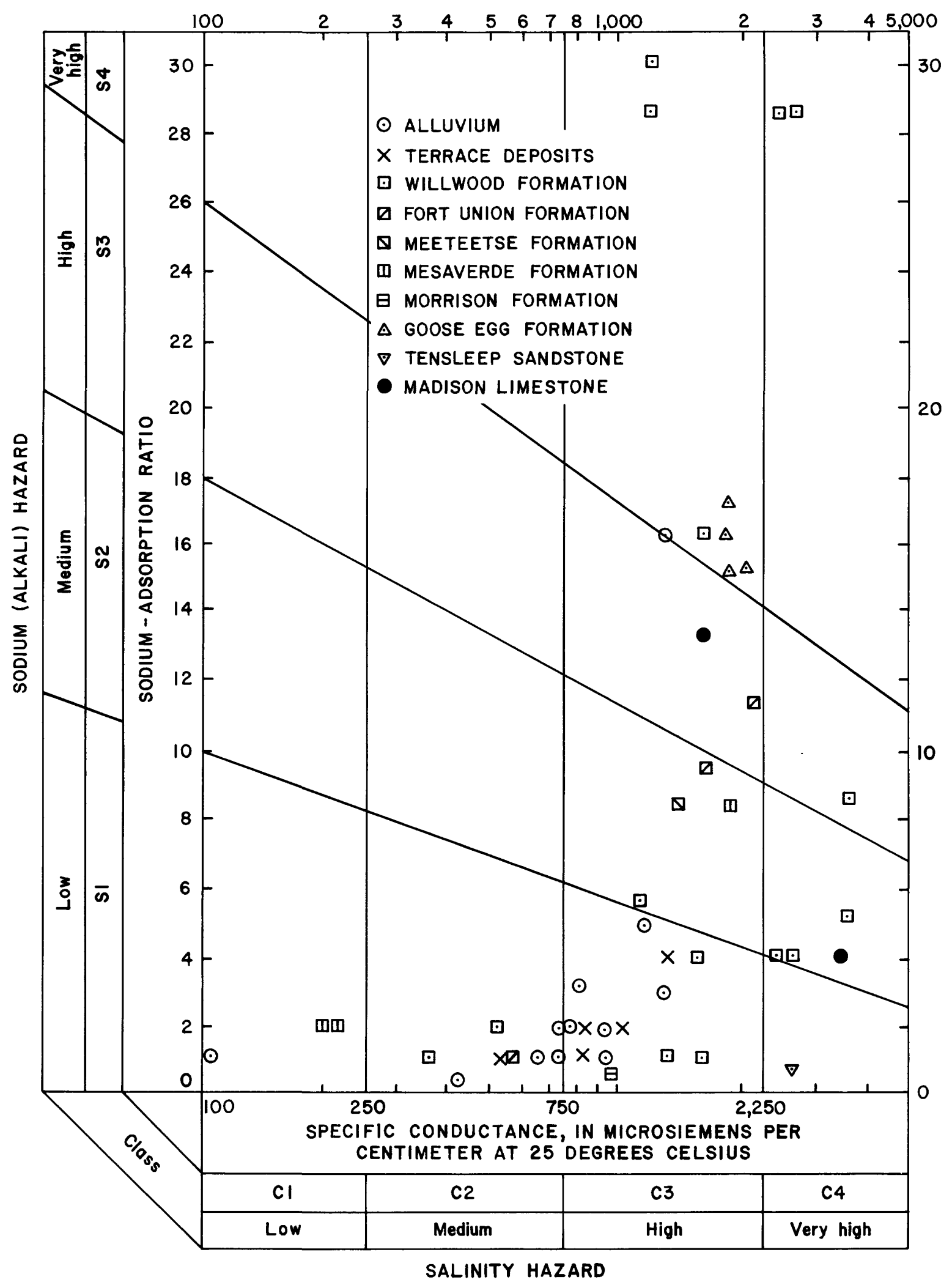

Figure 18.--Classification of ground water in Park County for irrigation use (classification developed by United States Salinity Laboratory staff, 1954). 


\section{CHEMICAL QUALITY OF WATER--Continued}

\section{Ground Water}

Unconsolidated Deposits

\section{Quality of Water in Terrace Deposits Depends Upon Development}

The quality of water in floodplain deposits is affected by streamflow and by human activity

The unconsolidated terrace deposits are saturated only when water has been applied for irrigation.

Therefore, the quality of water in the deposits is dependent upon the quality of water applied, the changes that occur as the result of using the water for irrigation, the residence time of water in the unconsolidated deposits, and human-induced changes. Changes caused by humans include application of agricultural chemicals, use of septic tanks, and pollution from spills that can be transported by ground water.

Water applied for irrigation may contain concentrations of dissolved solids on the order of a few hun- dred milligrams per liter, depending on the place of diversion from the source. Use of the water for irrigation concentrates the dissolved solids in the water by evaporation and transpiration and results in the addition of solids to the water by solution of materials in the deposits. The principal constituents dissolved are sodium and sulfate. Water from the terraces is dominantly a sodium sulfate type and contains concentrations of dissolved solids less than 1,000 milligrams per liter (fig. 19). (See chemical analyses of ground water from springs and water wells in the Supplemental Information section at the back of the report.)

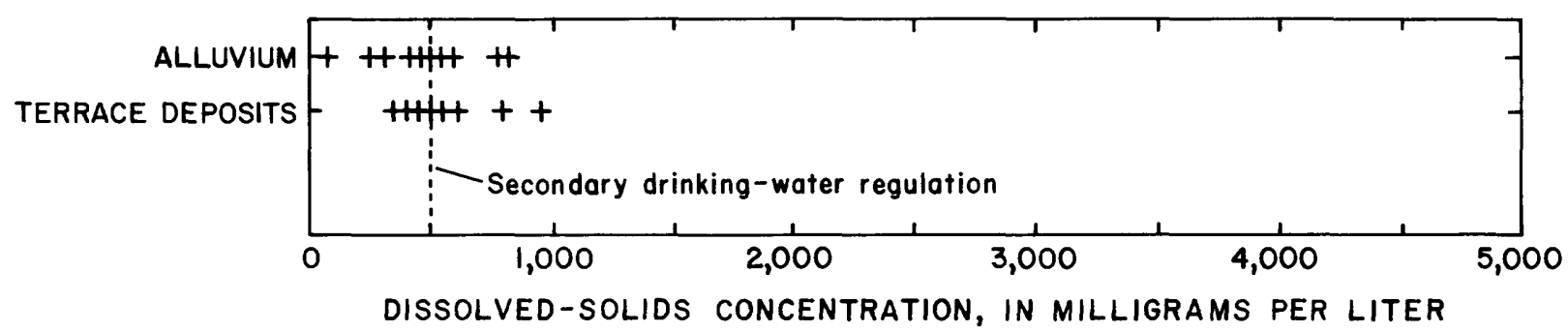

Figure 19.--Dissolved-solids concentration in water samples from unconsidated deposits in Park County. 
CHEMICAL QUALITY OF WATER--Continued

Ground-Water--Continued

Bedrock

\section{Water From Bedrock Generally Does Not Meet Secondary Drinking-Water Regulations}

Water from bedrock generally is suitable for livestock.

Water samples from only three bedrock formations had dissolved-solids concentrations less than the secondary maximum contaminant level of 500 milligrams per liter (fig. 20). Because of the poor quality of water from bedrock, many people in rural areas who rely on water from bedrock treat the water before using it for culinary purposes. Others buy potable water for drinking and use water from wells for other household purposes. Analyses of water samples collected by the U.S. Geological Survey are given in the table of chemical analyses of ground water from wells and springs in the Supplemental Information section.

Dissolved-solids concentrations in most bedrock formations were within the range acceptable for livestock use. The data are biased, however, because sam- ples were collected only from producing wells; no samples were collected from exploratory wells in which the water was found unsuitable for most purposes. Geologic units for which there are few data in the Supplemental Information section have not been developed as water supplies in the basin, in part because the quality of water in them is poor.

Most of the water sampled was in the high salinity hazard range for irrigation, using the criteria developed by the U.S. Salinity Laboratory (1954), (fig. 18). Water samples from three wells in the Willwood Formation, three wells in the Fort Union Formation, and one well each in the Frontier Formation, Thermopolis Shale, and Cloverly Formation had a SAR greater than 32 and are not shown on figure 18.

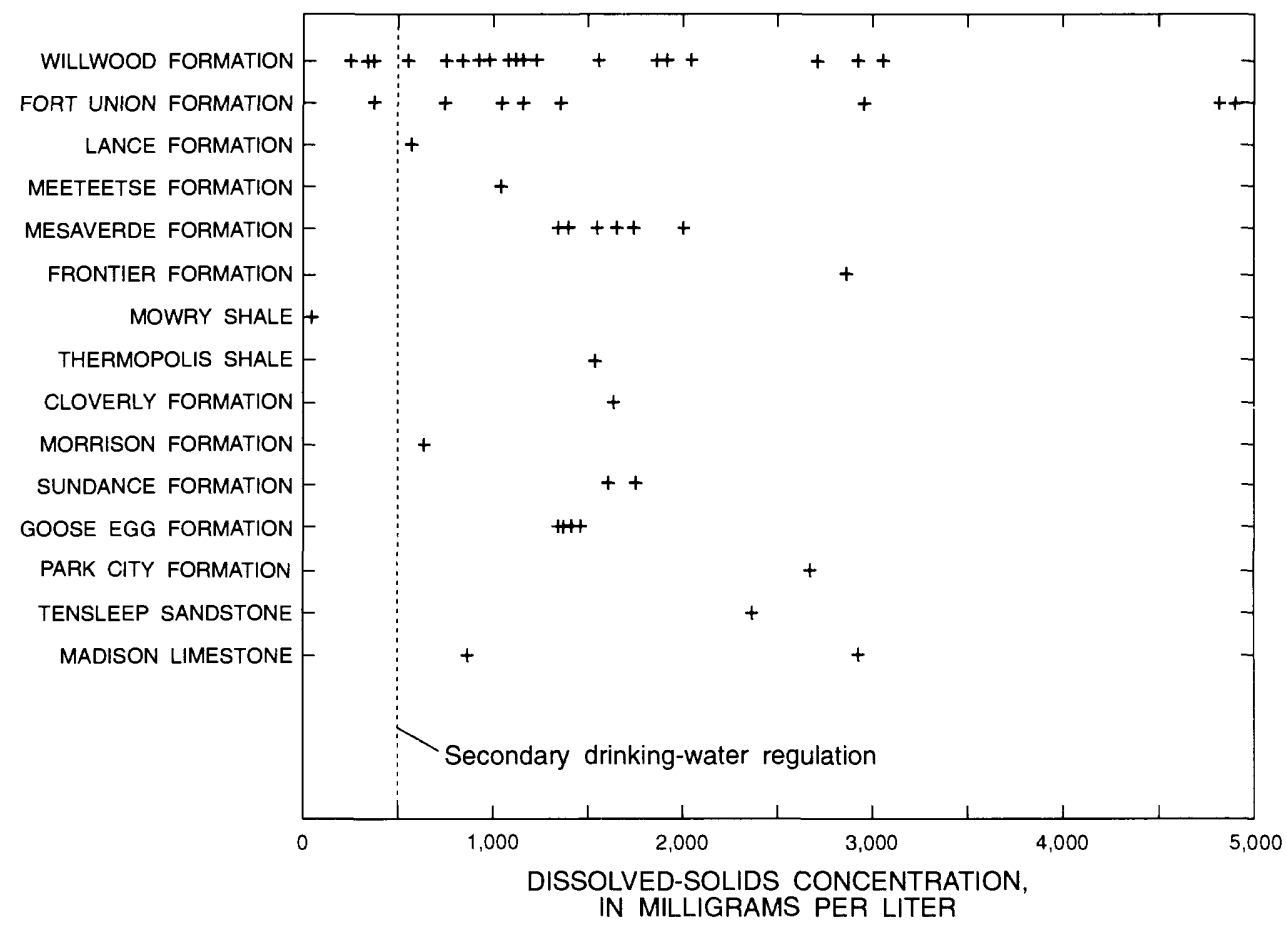

Figure 20.-Dissolved-solids concentration in water samples from bedrock in Park County. 


\title{
CHEMICAL QUALITY OF WATER--Continued
}

Surface Water

\section{Dissolved Solids in Perennial Streams Increase Downstream}

\author{
Irrigation, evapotranspiration, and increased contact with soluble material, \\ increase dissolved--solids concentration.
}

The predominant dissolved solids in water in perennial streams in the mountains are calcium and bicarbonate, and the dissolved-solids concentrations generally are less than 500 milligrams per liter. Dissolved-solids concentrations in the water are small because the sources of the water-either rainfall or snowmelt runoff-have small quantities of dissolved solids. Moreover, ground water has small dissolvedsolids concentrations because the aquifer materials in the mountains are relatively insoluble.

Dissolved-solids concentrations in streams increase downstream because of increased contact with more soluble material. This contact with more soluble material is multiplied by the diversion of water for irrigation and the subsequent return of the water to the streams. Also, consumptive use of water by diversion for irrigation, by riparian vegetation, and by evaporation reduces the amount of flow and increases the concentration of dissolved solids.

Seasonal variations in streamflow account for much of the variability in stream quality. Seasonal changes in the discharge and specific conductance (an index measure of dissolved-solids concentration) in Bitter Creek are shown in figure 21.

Bitter Creek is perennial because of return flow from irrigation and effluent from the town of Powell sewage treatment plant. During the irrigation season, flow in the creek is high because there is more direct return flow from irrigation, resident time of water in the aquifers is less, and, therefore, the conductivity of the water is relatively small. During the nonirrigation period, the conductivity of water in the stream is larger because the flow is from ground water that has a long resident time in the aquifers and from sewage effluent.

The load of dissolved solids in a stream (concentration $\times$ discharge $\times$ a factor) also increases downstream. In the Shoshone River between Buffalo Bill Reservoir (site 35) and Lovell (site 49), the discharge remains about the same. Figure 22 shows the cumulative dissolved-solids load which increases downstream from the reservoir to Lovell.

The concentrations and loads of dissolved solids in the ephemeral streams draining badlands and plains depend largely on the quantity of flow and the time since the last flow. Soluble salts that accumulate in the streambeds during no flow are flushed out during runoff. Therefore, the dissolved-solids concentration depends on time since the last flow. However, the initial flow has a larger concentration of dissolved solids than later flow in the same runoff. The load of dissolved solids moved during runoff also is dependent on the time since the last runoff. 


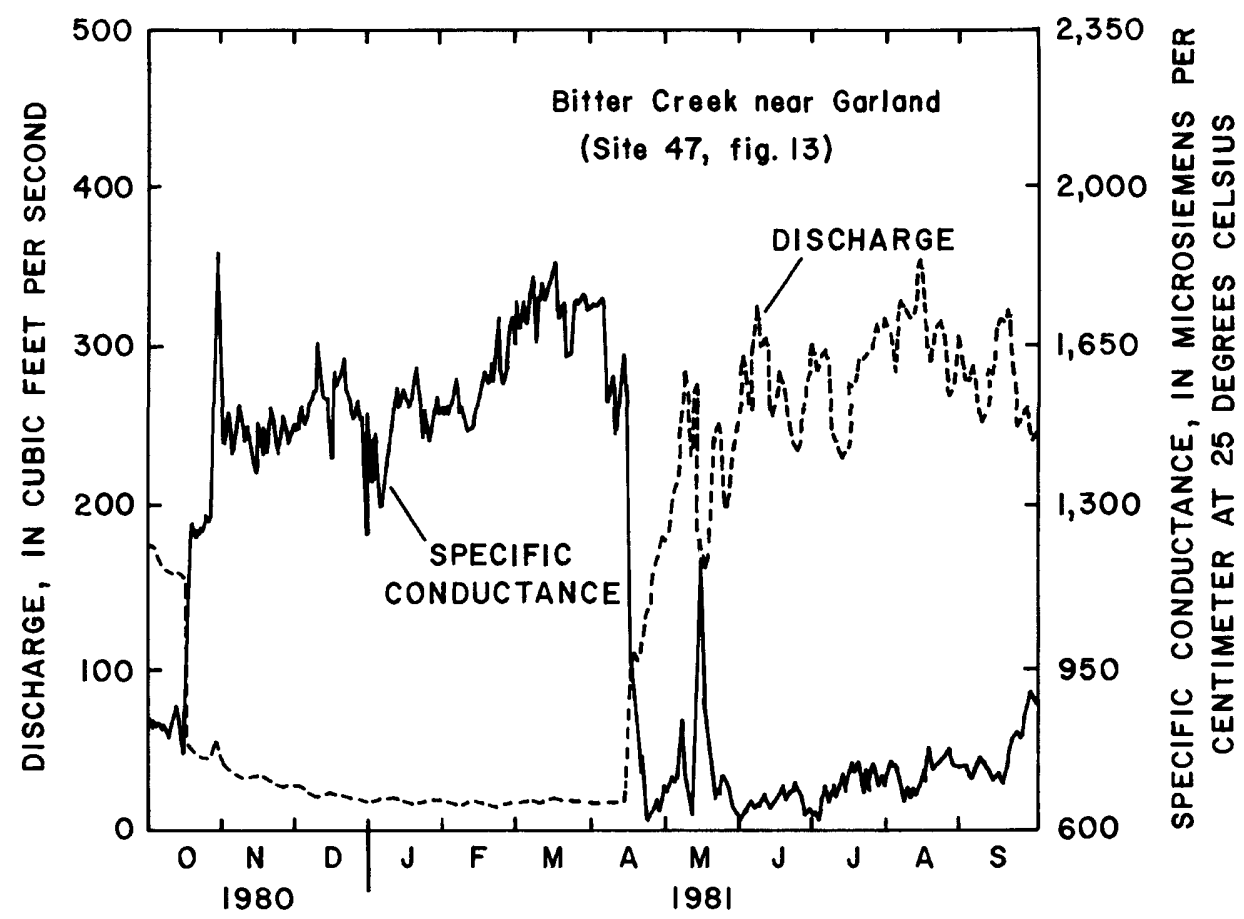

Figure 21.-Daily mean discharge and specific conductance of water in Bitter Creek near Garland, October 1980 through September 1981.

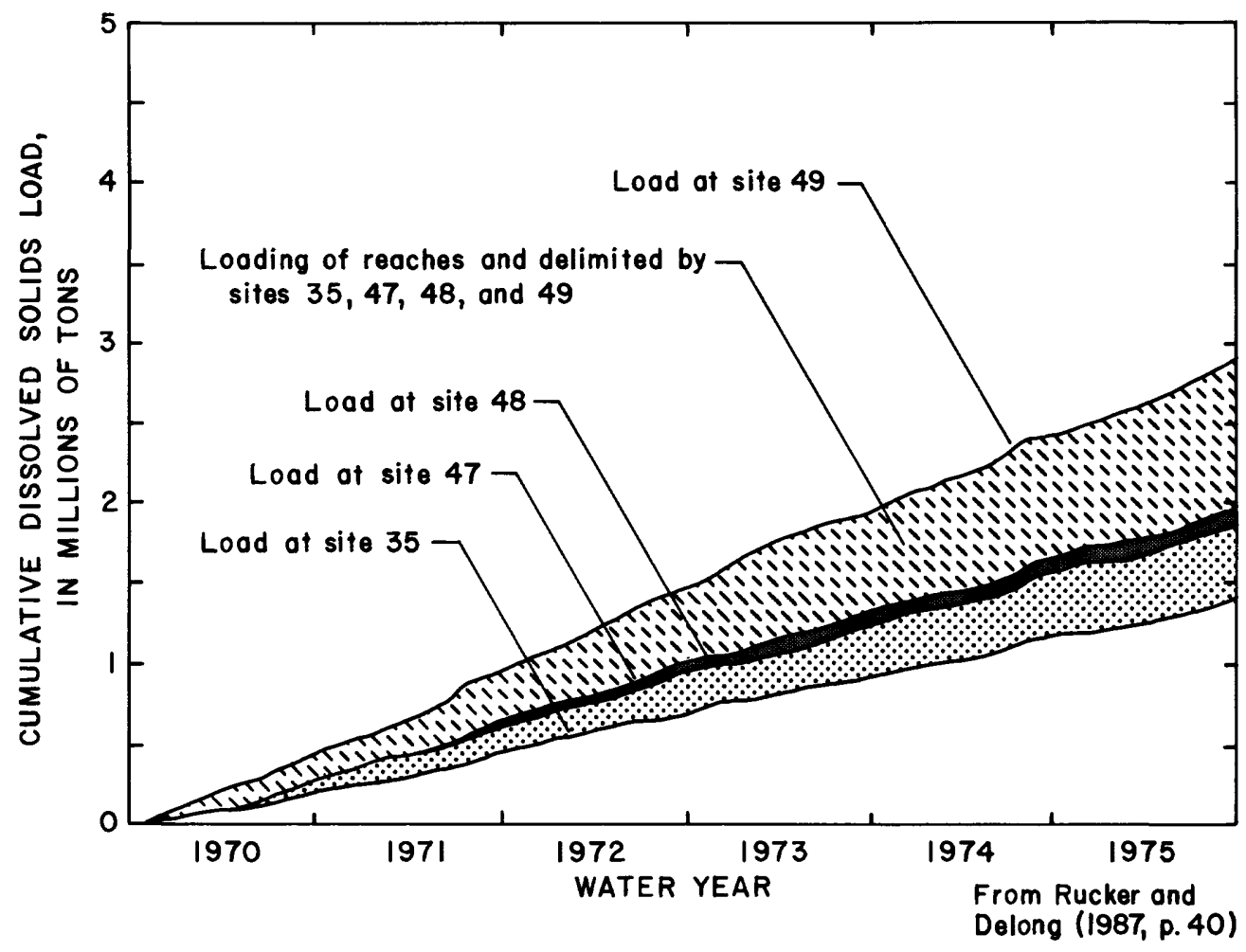

Figure 22.--Cumulative dissolved-solids load of the Shoshone River from below Buffalo Bill Reservoir to Lovell. 


\section{GLOSSARY}

\section{Terms in Report Defined}

Alluvium is clay, silt, sand, gravel, or similar unconsolidated material deposited by a stream or other body of running water.

Anticline is an arched fold in which the rock layers dip away from the axis of the fold.

Aquifer is a body of rock that contains sufficient saturated permeable material to yield significant quantities of water to wells and springs.

Average discharge is the arithmetic average of all complete water years of record of discharge whether consecutive or not.

Bedrock is a general term for the consolidated (solid) rock that underlies soils or other unconsolidated surficial material.

Clastic rocks are composed principally of broken rock fragments that are derived from pre-existing rocks or minerals and have been transported from their place of origin. The most common clastic rocks are sandstone and shale.

Colloid is material with a particle size smaller than clay size, fine-grained material in suspension, or material that may be easily suspended. (See particle-size classification.)

Colluvial deposit is heterogeneous incoherent soil or rock material that slowly moves (creeps) downslope. Although creep is too slow to be observed, the cumulative results become obvious over a period of years.

Cubic foot per second is the rate of discharge representing a volume of 1 cubic foot passing a given point during 1 second and is equivalent to about 7.48 gallons per second, 448.8 gallons per minute, or 0.02832 cubic meter per second.

Discharge is the volume of water (or generally, the volume of liquid plus suspended material) that passes a given point within a given period.

Dissolved refers to a substance present in true chemical solution. In practice, however, the term includes all forms of substances that will pass through a 0.45 -micrometer membrane filter, and thus may include some colloidal particles.
Drainage basin is the total area drained by a stream and its tributaries. Drainage area, determined planimetrically from topographic maps, is expressed in square miles.

Ephemeral stream is a stream that flows only in direct response to precipitation and whose channel is at all times above the water table.

Evapotranspiration is the withdrawal of water from surface water and soil by evaporation and plant transpiration. This water is transmitted to the atmosphere as vapor.

Fault is a fracture in bedrock along which movement of the bedrock has occurred.

Floodplain is the lowland that borders a river, usually dry but subject to flooding when the stream overflows its banks.

Formation is a body of rock identified by unique physical characteristics and relative position.

Gaging station is a particular site on a stream, canal, lake, or reservoir where hydrologic data are obtained on a regular or systematic basis.

Infiltration is the flow of water into soil at land surface, as contrasted with percolation, which is movement of water through soil layers or other surficial material.

Limestone is dense rock formed by chemical precipitation of calcium carbonate from solution in water.

Micrograms per liter is a unit expressing the concentration of chemical constituents in solution as mass (micrograms) of solute per unit volume (liter) of water. One thousand micrograms per liter is equivalent to 1 milligram per liter.

Milligrams per liter is a unit for expressing the concentration of chemical constituents in solution as mass (milligrams) of solute per unit volume (liter) of water. Concentration of suspended sediment also is expressed in milligrams per liter and is based on the mass (dry weight) of sediment per liter of watersediment mixture.

Particle size is the diameter, in millimeters, of any given sediment particle. (See particle-size classification.) 
Particle-size classification used by the U.S. Geological Survey:

$\begin{array}{lc}\begin{array}{l}\text { Classifi- } \\ \text { cation }\end{array} & \begin{array}{c}\text { Dimension limits, } \\ \text { in millimeters }\end{array} \\ \text { Clay } & 0.00024-0.004 \\ \text { Silt } & .004-.062 \\ \text { Sand } & .062-2.00 \\ \text { Gravel } & 2.00-64.0\end{array}$

Peak discharge (peak flow, flood peak) is the maximum instantaneous discharge during a specified time interval. The series of annual peak discharges at a gaging station is used to determine the recurrence interval (frequency) and exceedance probability of floods.

Pediment is a broad, gently sloping erosion surface developed at the base of a mountain range in a dry region and is usually covered with a thin layer of gravel.

Perennial stream is a stream that flows continuously.

Permeability is a measure of the relative ease with which a porous or fractured medium can transmit a liquid under a potential gradient (the capacity of a rock to transmit a fluid such as water or petroleum).

Potentiometric Surface is a surface that is defined by the levels to which water will rise in tightly cased wells.

Recharge is the process by which water is absorbed and added to the saturated zone (aquifer), either directly into a body of rock or indirectly by way of an adjacent body of rock. Also, it is the quantity of water that is added to the saturated zone.

Sandstone is the consolidated equivalent of sand. (See particle-size classification.)

Saturated zone is the subsurface zone in which all openings are full of water and are under hydrostatic pressure equal to or greater than atmospheric pressure.

Sediment is unconsolidated solid material that originates mostly from disintegrated rocks and is transported by water or air. Also, it may include chemical and biochemical precipitates or decomposed organic material, such as humus.

Shale is the consolidated equivalent of clay. (See particlesize classification.)

Siltstone is the consolidated equivalent of silt. (See particlesize classification.)
Soil refers to the layer of unconsolidated material on top of bedrock that supports plant growth.

Specific capacity is the yield of a well per unit of drawdown.

Specific conductance is a measure of the ability of the water to conduct an electrical current. It is expressed in microsiemens per centimeter at 25 degrees Celsius. Specific conductance is related to the type and concentration of ions in solution and can be used for approximating the dissolved-solids concentration of the water.

Stage is the height of a water surface above an established datum plane.

Streamflow is the discharge in a natural channel. Although the term "discharge" can be applied to a flow of a canal, the word "streamflow" is used only to describe the discharge in a surface-stream course.

Suspended-sediment concentration is the velocityweighted concentration of suspended sediment in a sampled zone, expressed as milligrams of dry sediment per liter of water-sediment mixture.

Suspended-sediment discharge is the rate at which suspended sediment is transported through a cross section of a stream.

Terrace is a step-like landform above a stream and its floodplain, representing a former, abandoned floodplain of a stream.

Transpiration is the process by which water vapor escapes from a living plant and enters the atmosphere.

Unconsolidated refers to sediment grains that are loose, separate, or unattached to one another.

Unsaturated zone is the zone between the land surface and the deepest water table. It includes the capillary fringe. Generally, water in this zone is under less than atmospheric pressure, and some of the voids may contain air or other gases at atmospheric pressure.

Volcaniclastic refers to a clastic rock containing volcanic material.

Water table refers to the upper surface of the saturated zone; the water pressure is equal to atmospheric pressure. 


\section{Extensive Hydrologic and Geologic Literature Listed}

Back, William, and Freeze, R.A., 1983, Chemical hydrogeology, Benchmark papers in hydrology, v. 73: Hutchinson Ross Publishing Company, $416 \mathrm{p}$.

Bown, T.M., 1975, Paleocene and lower Eocene rocks in the Sand Creek-No Water Creek area,

Washakie County, Wyoming, in Exum, F.A., and George, G.R., eds., Geology and mineral resources of the Bighorn Basin: Wyoming Geological Association 27th Annual Field Conference Guidebook, p. 55-61.

Breckenridge, R.M., and Hinckley, B.S., 1978, Thermal springs of Wyoming: Laramie, Wyoming, The Geological Survey of Wyoming Bulletin 60, $104 \mathrm{p}$.

Bredehoeft, J.D., 1964, Variation of permeability in the Tensleep Sandstone in the Bighorn Basin, Wyoming, as interpreted from core analyses and geophysical logs: U.S. Geological Survey Professional Paper 501-D, p. D166-D170.

Bredehoeft, J.D., and Bennett, R.R., 1972, Potentiometric surface of the Tensleep Sandstone in the Bighorn Basin, west-central Wyoming:

U.S. Geological Survey Open-File Report 72-461.

Bredehoeft, J.D., Papadopulos, S.S., and Cooper, H.H., 1982, Groundwater: The water-budget myth, in Studies in geophysics, scientific basis of water-resources management: National Academy Press, p. 51-57.

Bullock, J.M., and Wilson, W.H., 1969, Gypsum deposits in the Cody area, Park County, Wyoming: Laramie, Wyoming, The Geological Survey of Wyoming Preliminary Report, no. 9, $12 \mathrm{p}$.

Cooley, M.E., 1986, Artesian pressures and water quality in the Ten Sleep area of the Bighorn basin, north-central Wyoming: U.S. Geological Survey Water-Supply Paper 2289, 54 p.

Cooley, M.E., and Head, W.J., 1979, Hydrogeologic features of the alluvial deposits in the Greybull River valley, Bighorn Basin, Wyoming: U.S. Geological Survey Water-Resources Investigations Report 79-6, 38 p.
1982, Hydrogeologic features of the alluvial deposits in the Owl Creek valley, Bighorn Basin, Wyoming: U.S. Geological Survey WaterResources Investigations Report 82-4007, $37 \mathrm{p}$.

Cox, E.R., 1976, Water resources of northwestern Wyoming: U.S. Geological Survey Hydrologic Investigations Atlas HA-558, scale 1:250,000, 3 sheets.

Craig, G.S., Jr., and Rank1, J.G., 1978, Analysis of runoff from small drainage basins in Wyoming: U.S. Geological Survey Water-Supply Paper 2056, 70 p.

Culler, R.C., 1961, Hydrology of stock-water reservoirs in upper Cheyenne River basin, in Hydrology of the upper Cheyenne River basin: U.S. Geological Survey Water-Supply Paper 1531, Part A, p. 1-136.

DeLong, L.L., 1977, An analysis of salinity in streams of the Green River Basin, Wyoming: U.S. Geological Survey Water-Resources Investigations Report 77-103, 32 p.

Eaton, F.M., 1950, Significance of carbonates in irrigation waters: Soil Science, v. 69 , no. 2, p. 123-133.

Edwards, M.D., 1980, Directory of assistance centers of the National Water Data Exchange (NAWDEX): U.S. Geological Survey Open-File Report 80-1193, 14 p.

Glover, K.C., 1984, Storage analyses for ephemeral streams in semiarid regions: U.S. Geological Survey Water-Resources Investigations Report 83-4078, 55 p.

Grose, L.T., 1972, Tectonics, in Geological atlas of the Rocky Mountain region, United States of America: Rocky Mountain Association of Geologists, Denver, p. 35-44.

Harris, R.E., 1983, Uranium and industrial minerals, in Glass, G.B., Minerals outlook for Wyoming: Laramie, Wyoming, The Geological Survey of Wyoming Information Circular, v. 1, no. 4, 31 p.

Hausel, W.D., 1982, Ore deposits of Wyoming: Laramie, Wyoming, The Geological Survey of Wyoming Preliminary Report, no. 19, 39 p. 
Hausel, W.D., Glass, G.B., Lageson, D.R., Ver Ploeg, A.J., and De Bruin, R.H., 1979, Wyoming mines and minerals, 1979: Laramie, Wyoming, The Geological Survey of Wyoming map, 1 sheet, scale $1: 500,000$.

Heasler, H.P., Hinckley, B.S., Buelow, K.G., Spencer, S.A., and Decker, E.R., 1983, Geothermal resources of Wyoming, 1983: Laramie, Wyoming, The Geological Survey map, scale $1: 500,000$.

Heath, R.C., 1983, Basic ground-water hydrology: U.S. Geological Survey Water-Supply Paper 2220, 84 p.

Hem, J.D., 1985 (3d ed.), Study and interpretation of the chemical characteristics of natural water: U.S. Geological Survey Water-Supply Paper 2254, $263 \mathrm{p}$.

Hendricks, E.L., 1964, Compilation of records of surface waters of the United States, October 1950 to September 1960: U.S. Geological Survey Water-Supply Paper 1729, 507 p.

Hewett, D.F., 1926, Geology and oil and coal resources of the Oregon Basin, Meeteetse, and Grass Creek Basin quadrangles, Wyoming: U.S. Geological Survey Professional Paper 145, $111 \mathrm{p}$.

Hinckley, B.S., Heasler, H.P., and King, J.K., 1982, The Thermopolis hydrothermal system with an analysis of Hot Springs State Park: Laramie, Wyoming, The Geological Survey of Wyoming Preliminary Report, no. 20, 42 p.

Houston, R.S., 1971, Regional tectonics of the Precambrian rocks of the Wyoming province and its relationship to Laramide structure, in Wyoming Geological Association 23rd Field Conference Guidebook, p. 19-27.

Huntoon, P.W., 1985, Fault severed aquifers along the perimeters of Wyoming artesian basins: Ground Water, v. 23, no. 5, p. 176-181.

Johnson, Edward R., Inc., 1966, Ground water and wells: Edward R. Johnson, Inc., 440 p.

Keefer, W.R., 1965, Stratigraphy and geologic history of the uppermost Cretaceous, Paleocene, and lower Eocene rocks in the Wind River Basin, Wyoming: U.S. Geological Survey Professional Paper 495-A, $77 \mathrm{p}$.

1972, Frontier, Cody, and Mesaverde Formations in the Wind River and southern Bighorn Basins, Wyoming: U.S. Geological Survey Professional Paper 495-E, $23 \mathrm{p}$.

Konikow, L.F., and Person, Mark, 1985, Assessment of long-term salinity changes in an irrigated stream-aquifer system: Water Resources Research, v. 21, no. 11, p. 1611-1624.
Langbein, W.B., and Iseri, K.T., 1960, General introduction and hydrologic definitions: U.S. Geological Survey Water-Supply Paper 1541-A, $29 \mathrm{p}$.

Larson, L.R., 1984, Ground-water quality in Wyoming: U.S. Geological Survey WaterResources Investigations Report 84-4034, 71 p.

Lawless, E.W., Ferguson, T.L., and Meiners, A.F., 1975, Guidelines for disposal of small quantities of unused pesticides: Prepared by the Midwest Research Institute for the U.S. Environmental Protection Agency, 331 p.

Libra, Robert, Doremus, Dale, and Goodwin, Craig, 1981, Occurrence and characteristics of ground water in the Bighorn Basin, Wyoming: Laramie, Wyoming, Water Resources Research Institute, $114 \mathrm{p}$.

Lindsey, D.A., 1972, Sedimentary petrology and paleocurrents of the Harebell Formation, Pinyon Conglomerate, and associated coarse clastic deposits, northwestern, Wyoming: U.S. Geological Survey Professional Paper 734-B, $68 \mathrm{p}$.

Love, J.D., 1973, Harebell Formation (Upper Cretaceous) and Pinyon Conglomerate (uppermost Cretaceous and Paleocene), northwestern Wyoming: U.S. Geological Survey Professional Paper 734-A, 54 p.

Love, J.D., and Christiansen, A.C., 1985, Geologic map of Wyoming: U.S. Geological Survey map, scale $1: 500,000,3$ sheets.

Love, J.D., Weitz, J.L., and Hose, R.K., 1955, Geologic map of Wyoming: U.S. Geological Survey map, scale 1:500,000.

Lowham, H.W., 1988, Streamflows in Wyoming: U.S. Geological Survey Water-Resources Investigations Report 88-4045, 78 p.

Lowham, H.W., Kircher, J.E., and Boner, F.C., 1975, Temperatures of Wyoming streams: Wyoming State Engineer's Office, Wyoming Water Planning Program Report No. 15, 115 p.

Lowry, M.E., Lowham, H.W., and Lines, G.C., 1976, Water resources of the Bighorn Basin, northwestern Wyoming: U.S. Geological Survey Hydrologic Investigations Atlas HA-512, scales $1: 250,000$ and $1: 500,000,2$ sheets.

Mackin, J.H., 1937, Erosional history of the Bighorn Basin, Wyoming: Geological Society of America Bulletin, v. 48, p. 813-893.

Martner, B.E., 1986, Wyoming climate atlas: Lincoln, University of Nebraska Press, 432 p.

McKee, J.E., and Wolf, H.W., eds., 1971, Water quality criteria [2d ed]: California State Water Quality Control Board Publication 3-A, 548 p. 
McIntosh, W.L., and Eister, M.F., 1979, Geologic map index of Wyoming: U.S. Geological Survey maps, 13 sheets.

Miller, W.R., and Drever, J.I., 1977, Water chemistry of a stream following a storm, Absaroka Mountains, Wyoming: Geologic Society of America Bulletin, v. 88, no. 2, p. 286-290.

Moore, E.W., 1940, Progress report of the committee on quality tolerances of water for industrial uses: New England Water Works Association Journal, v. 54, p. 271.

National Academy of Sciences and National Academy of Engineering, 1973 [1974], Water quality criteria, 1972: U.S. Government Printing Office, $594 \mathrm{p}$.

National Oceanic and Atmospheric Administration, 1973, Monthly normals of temperature, precipitation, and heating and cooling days 1941-70: U.S. Department of Commerce Publication, Climatography of the United States, no. 81 (Wyoming), 8 p.

Parrett, Charles, Carlson, D.D., Craig, Jr., G.S., and Chin, E.H., 1984, Floods of May 1978 in southeastern Montana and northeastern Wyoming: U.S. Geological Survey Professional Paper 1244, 74 p.

Peterson, D.A., Mora, K.L., Lowry, M.E., Rankl, J.G., Wilson, J.F., Jr., Lowham, H.W., and Ringen, B.H., 1987, Hydrology of area 51, northern Great Plains and Rocky Mountain coal provinces, Wyoming and Montana: U.S. Geological Survey, Water-Resources Investigations Open-File Report 84-734

Pierce, W.G., 1948, Geologic and structure contour map of the Basin-Greybull area, Big Horn County, Wyoming: U.S. Geological Survey Oil and Gas Investigations Preliminary Map OM-77, scale 1:48,000.

1965, Geologic map of the Deep Lake quadrangle, Park County, Wyoming: U.S. Geological Survey Geologic Quadrangle Map GQ-478, scale 1:62,500.

1966, Geologic map of the Cody quadrangle, Park County, Wyoming: U.S. Geological Survey Geologic Quadrangle Map GQ-542, scale $1: 62,500$.

1970, Geologic map of the Devils Tooth quadrangle, Park County, Wyoming: U.S. Geological Survey Geologic Quadrangle Map GQ-817, scale 1:62,500.

1978, Geologic map of the Cody $1^{\circ}$ by $2^{\circ}$ quadrangle, northwestern Wyoming: U.S. Geological Survey Miscellaneous Field Studies Map MF-963, scale 1:250,000.
Pierce, W.G., and Nelson, W.H., 1968, Geologic map of the Pat O'Hara Mountain quadrangle, Park County, Wyoming: U.S. Geological Survey Geologic Quadrangle Map GQ-755, scale 1:62,500.

1969, Geologic map of the Wapiti quadrangle, Park County, Wyoming: U.S. Geological Survey Geologic Quadrangle Map GQ-778, scale 1:62,500.

1971, Geologic map of the Beartooth Butte quadrangle, Park County Wyoming: U.S. Geological Survey Geologic Quadrangle Map GQ-935, scale 1:62,500.

Plafcan, Maria, and Ogle, K.M., in press, Water resources of Hot Springs County, Wyoming: U.S. Geological Survey Water-Resources Investigations Report 93-4141.

Plafcan, Maria, Cassidy, E.W., and Smalley, M.L., in press, Water resources of Big Horn County, Wyoming: U.S. Geological Survey WaterResources Investigations Report 93-4021.

Ragsdale, J.O., 1982, Ground-water levels in Wyoming, 1971 through part of 1980: U.S. Geological Survey Open-File Report 82-859, 203 p.

Rechard, P.A., and Ragsdale, C.E., 1971, Compacts, treaties, and court decrees: Laramie, Wyoming, Water Resources Research Institute, Land and Water Law Center, 163 p.

Ringen, B.H., 1973, Records of ground-water levels in Wyoming, 1940-1971: Wyoming State Water Planning Program Report No. 13, 479 p.

Ritter, D.F., 1975, New information concerning the geomorphic evolution of the Bighorn Basin, in Exum, F.A., and George, G.R., eds., Geology and mineral resources of the Bighorn Basin: Wyoming Geological Association 27th Annual Field Conference Guidebook, p. 37-44.

Robinove, C.J., and Langford, R.H., 1963, Geology and ground-water resources of the Greybull River-Dry Creek area, Wyoming: U.S. Geological Survey Water-Supply Paper 1596, $88 \mathrm{p}$.

Rohrer, W.L., 1964, Geology of the Tatman Mountain quadrangle, Wyoming: U.S. Geological Survey Geologic Quadrangle Map GQ-311, scale 1:24,000.

1965, Geologic map of the Adam Weiss Peak quadrangle, Hot Springs and Park Counties, Wyoming: U.S. Geological Survey Geologic Quadrangle Map GQ-382, scale 1:24,000. 
1966, Geology of the Adam Weiss Peak quadrangle, Hot Springs and Park Counties, Wyoming: U.S. Geological Survey Bulletin 1241-A, 39 p.

Ross, C.P., Andrews, D.A., and Witkind, I.J., 1955, Geologic map of Montana: U.S. Geological Survey map, 2 sheets, scale 1:500,000.

Rucker, S.J., IV, and DeLong, L.L., 1987, Evaluation of selected surface-water-quality stations in Wyoming: U.S. Geological Survey WaterResources Investigations Report 82-4003, 72 p.

Shoaff, L.A., Flot, T.R., and Lutz, G.A., 1978, Leasable mineral and waterpower land classification map of the Cody $1^{\circ}$ by $2^{\circ}$ quadrangle, Wyoming: U.S. Geological Survey Miscellaneous Investigations Map I-1107, scale $1: 250,000,1$ sheet.

Searcy, J.K., 1959, Flow-duration curves: U.S. Geological Survey Water-Supply Paper 1542-A, $33 \mathrm{p}$.

Sterns, D.W., 1975, Laramide basement deformation in the Bighorn Basin--The controlling factor for structures in the layered rocks, in Wyoming Geological Association 27th Annual Field Conference Guidebook, p. 149-158.

1971, Mechanisms of drape folding in the Wyoming Province, in Wyoming Geological Association 23rd Annual Field Conference Guidebook, p. 125-143.

Susong, D.D., Smalley, M.L., and Banta, E.R., 1993, Water Resources of Washakie County, Wyoming: U.S. Geological Survey Water-Resources Investigations Report 91-4044, 82 p.

Swenson, H.A., 1957, Geology and ground water, Heart Mountain and Chapman Bench Divisions, Shoshone irrigation project, Wyoming: U.S. Geological Survey Water-Supply Paper 1418, $55 \mathrm{p}$.

U.S. Department of Agriculture, 1974, Wind-BighornClarks Fork River Basin, main report: Soil Conservation Service, Economic Research Service, Forest Service, type IV survey, variable pagination.

U.S. Department of Commerce, 1984, National Climatic Center computer data base: National Oceanic and Atmospheric Administration, Asheville, North Carolina.

U.S. Environmental Protection Agency, 1976, Quality criteria for water U.S. Government Printing Office, U.S. Environmental Protection Agency Report, EPA-440/9-76-023, 256 p. 1989a, Primary drinking-water regulations, maximum contaminant levels (subpart B of part 141, National primary drinking-water regulations): U.S. Code of Federal Regulations, Title 40, Parts 100-149, revised as of July 1, 1989, p. 547-550.

1989b, Secondary drinking-water regulations, secondary maximum contaminant levels (section 143.3 of part 143 , National secondary drinkingwater regulations): U.S. Code of Federal Regulations, Title 40, Parts 100-149, revised as of July 1, 1989, p. 656.

U.S. Geological Survey, 1969, Surface water supply of the United States, 1961-65--Part 6, Missouri River basin--Volume 1, Missouri River basin above Williston, North Dakota: U.S. Geological Survey Water-Supply Paper 1916, 800 p. issued annually since 1965 , Water-resources data for Wyoming: U.S. Geological Survey WaterData Reports.

U.S. Salinity Laboratory, 1954, Diagnosis and improvement of saline and alkali soils: U.S. Department of Agriculture Handbook 60, 160 p.

U.S. Soil Conservation Service, 1977, Average annual precipitation in Montana based on 1941-1970 base period: Bozeman, Montana, 13 p.

Ver Ploeg, A.J., 1982, Wyoming's oil and gas industry: Laramie, Wyoming, The Geological Survey of Wyoming Public Information Circular No. 17,20 p.

Vogt, E.Z., and Hyman, Ray, 1959, Water witching, USA: The University of Chicago Press, $248 \mathrm{p}$.

Wells, J.V.B., 1959, Compilation of records of surface waters of the United States through September 1950: U.S. Geological Survey Water-Supply Paper 1309, Part 6-A, 672 p.

Wilson, W.H., 1964, The Kirwin mineralized area, Park County, Wyoming: Laramie, Wyoming, The Geological Survey of Wyoming Preliminary Report No. 2, 12 p.

Wyoming Department of Administration and Fiscal Control, 1981, Wyoming data handbook 1981: Cheyenne, Division of Research and Statistics, 5th edition, $201 \mathrm{p}$.

1983, Wyoming data handbook 1983: Cheyenne, Division of Research and Statistics, 6th edition, $206 \mathrm{p}$.

Wyoming Game and Fish Commission, 1969, Investigation of oilfield pollution in the Byron Lovell area: Wyoming Game and Fish Commission project 02a69-07-69.

Wyoming State Engineer, 1972, Water and related land resources of the Bighorn River Basin, Wyoming: Cheyenne, Wyoming, Wyoming Water Planning Program Report No. 11, 231 p. 


\section{SUPPLEMENTAL INFORMATION}




\section{SUPPLEMENTAL INFORMATION--Continued}

Description of Geologic Units and Potential Availability of Ground Water in Park County, Wyoming

Geologic unit and lithologic description ${ }^{1}$

ALLUVIUM--Unconsolidated deposits of silt, sand, gravel, and cobbles. May include some colluvium, which is heterogeneous deposits of rock fragments.

TERRACE AND PEDIMENT DEPOSITS:

TERRACE DEPOSITS--Unconsolidated deposits of silt, sand, and gravel.

PEDIMENT DEPOSITS--Veneer of poorly rounded to subangular surficial material deposited on smooth, gently sloping erosion surface cut on bedrock. May include some fan and glacial deposits and Tertiary gravels.

GLACIAL DEPOSITS--Till and outwash of sand, gravel, and boulders.

LANDSLIDE DEPOSITS--Heterogeneous deposits or rock debris emplaced by mass movement.

UNDIVIDED SURFICIAL DEPOSITS--Mostly alluvium, colluvium, and glacial and landslide deposits.

\section{HUCKLEBERRY RIDGE TUFF OF YELLOWSTONE} GROUP, CALDWELL CANYON VOLCANICS, IGNEOUS ROCKS, TERTIARY INTRUSIVE, AND ABSAROKA VOLCANIC SUPERGROUP-Nonintrusive rocks are predominantly volcanic sediments interfingering with volcanic flows in the south, and agglomerates and tuffs in the north.
Alluvium will yield adequate quantities for domestic or stock use where saturated; thickness limits yield from most deposits. Colluvium is not considered an aquifer.

Yield of the deposits is restricted by saturated thickness, and yield to conventional wells generally is less than 100 gallons per minute. Saturated deposits in the basin occur only as the result of irrigation.

Pediment deposits are not considered an aquifer.

Springs are common and yields of 100 gallons per minute, or more, are possible. However, drilling is difficult in many areas because of large boulders; also, deposits occur where surface water generally is plentiful.

Springs are a source of water in some areas but wells generally do not yield much water because the deposits are from fine-grained material, and deposition by mass movement increases heterogeneity.

Availability depends on type of deposits as already described.

Availability differs greatly because of diverse lithology. Yields from clastic rocks range from those described for alluvium to those described for shale. Yield from volcanic flows and intrusive rocks would be similar to that described for Precambrian rocks. Springs are common and some may be developed as potential sources of water. 


\section{SUPPLEMENTAL INFORMATION--Continued}

Description of Geologic Units and Potential Availability of Ground Water in Park County, Wyoming--Continued

Not considered an aquifer because it occurs only on mountaintops and is not saturated.

WILLWOOD FORMATION--varicolored clay, sandstone, and shale; some carbonaceous shale containing thin coal lenses; locally, some conglomerate in the lower part. Maximum thickness 3,300 feet.

CRANDALL CONGLOMERATE--Stream-channel deposits of well-cemented coarse conglomerate.

FORT UNION FORMATION--Thin-bedded lightcolored sandstone and conglomerate; drab to olivebrown shale and some red shale; some carbonaceous shale and thin beds of coal. Maximum thickness 5,600 feet.

INTRUSIVE IGNEOUS ROCKS--Gray to buff monzonite porphyry.

LANCE FORMATION--Thick-bedded buff-colored sandstone and drab to green shale. Maximum thickness 1,600 feet.
TATMAN FORMATION--Brown papery carbonaceous and calcareous shale interbedded with drab-olivegray bentonitic clay and sandstone; thin coal beds at or near base locally.

Ground water is available from sandstone layers throughout this formation, and because of the large thickness, large yields would be possible. However, supplies are not always available at shallow depth. Wells drilled to depths of 600 feet for stock supplies in adjoining counties have been unsuccessful.

Very localized aquifer because of small extent and location near perennial streams.

Availability of water is similar to that from Willwood Formation except some sandstone aquifers are more extensive than those in the Willwood. However, unsuccessful wells for stock water supplies have been drilled to 450 feet in adjoining counties.

Localized aquifer since it occurs only in the Beartooth Mountains. Availability of water would be similar to that in Precambrian rocks.

Yields of 1,000 gallons per minute may be possible because of the large thickness. Yields sufficient for stock or domestic supplies can be obtained more readily from shallow wells in the Lance Formation than from the Willwood or the Fort Union Formations because sandstone aquifers are more extensive and individual sands are thicker.
MEETEETSE FORMATION--Gray to white clayey sand, drab sandstone, gray and brown shale, and bentonitic clay. Maximum thickness 1,300 feet. do.

do.
MESAVERDE FORMATION--Interbedded light-gray sandstone and gray shale in upper part; lower part massive light-buff ledge-forming sandstone containing thin, lenticular coal beds. Thickness 660 to 1,300 feet. 


\title{
SUPPLEMENTAL INFORMATION--Continued
}

\author{
Description of Geologic Units and Potential Availability of Ground Water in Park County, \\ Wyoming--Continued
}

CODY SHALE--Upper part buff sandy shale and thinly laminated buff sandstone; lower part dark-gray thinbedded shale. Thickness 1,600 to 3,300 feet.

FRONTIER FORMATION--Thick lenticular gray sandstone, gray shale, brown carbonaceous shale, and bentonite. Thickness 43 to 560 feet.

MOWRY SHALE--Gray and brown shale, in part siliceous; contains numerous bentonite beds. Thickness 330 to 443 feet.

THERMOPOLIS SHALE--Soft black shale containing numerous bentonite beds. Muddy Sandstone Member about 200 feet above base. Thickness 390 to 590 feet.

CLOVERLY FORMATION--Light-gray sandstone, gray conglomerate. Thickness 110 to 200 feet.

MORRISON FORMATION--Dully variegated claystone and gray silty sandstone. Thickness 330 to 490 feet.

SUNDANCE FORMATION--Green and gray shale, greenish-gray limy sandstone, and thin beds of gray limestone. Thickness 360 to 460 feet.

GYPSUM SPRING FORMATION--Red and gray shale, limestone, and gypsum. Thickness 70 to 230 feet.

CHUGW ATER FORMATION--Red siltstone, red shale, and fine-grained red sandstone; gypsiferous.

Thickness 590 to 820 feet.
Not considered an aquifer. Water supplies in areas where this unit crops out generally are obtained from alluvium, deeper aquifers, or by importing water from outside the outcrop area.

Small yields can be obtained from sandstone. However, no water wells are known to be completed in this formation in the county.

Yields about 100 gallons per minute to a spring in T. 54 N., R. 102 W., sec. 34 , but no water wells are known to be completed in this shale. Because the shale is brittle, small yields probably can be obtained in areas where structures have increased the secondary permeability.

Small supplies available only from the Muddy Sandstone Member. No water wells are known to be completed in this shale in the area.

Will yield adequate supplies of water for domestic or stock supplies.

Not considered an aquifer.

Sandstone would yield small adequate quantities of water for stock or domestic supplies. However, the formation is at the depth of conventional water wells only near the mountains where other sources of water generally are adequate, and no water wells are known to be completed in this formation in the area.

Not considered an aquifer. 


\section{SUPPLEMENTAL INFORMATION--Continued}

Description of Geologic Units and Potential Availability of Ground Water in Park County,

Wyoming--Continued

Geologic unit and lithologic description

DINWOODY FORMATION--Tan, gray, and red siltstone, gypsum, and dolomite. Thickness 20 to 49 feet.

GOOSE EGG FORMATION--Red sandstone and siltstone, white gypsum beds, halite, and purple to white dolomite and limestone.

\section{PHOSPHORIA FORMATION AND RELATED}

ROCKS--Siliceous limestone and dolomite, nodular chert, and tannish-gray shale. Thickness 49 to 160 feet.

PARK CITY FORMATION--Siliceous limestone and dolomite, nodular chert, and tan and gray shale. Thickness 70 to 110 feet. Includes intertonguing parts of Phosphoria Formation.

TENSLEEP SANDSTONE--Light-gray well-sorted crossbedded massive sandstone; thin beds of gray limestone and dolomite in the lower part. Thickness about 130 to 250 feet.

AMSDEN FORMATION--Red shale containing some gray dolomitic limestone beds; some chert and hematite nodules; basal part commonly red siltstone or sandstone. Thickness 150 to 300 feet.

MADISON LIMESTONE--Blue-gray massive limestone, dolomitic in part; upper half somewhat thicker bedded and more massive than the lower half. Thickness 490 to 980 feet.

\section{Potential availability of ground water}

May yield adequate supplies of water for domestic or stock supplies.

Not considered an aquifer.

May yield adequate supplies of water for domestic or stock supplies.

Will readily yield adequate quantities of water for stock or domestic use, and artesian flows as large as 300 gallons per minute have been developed in the adjoining counties. However, the sandstone occurs at depths of more than 1,000 feet within a short distance east of the mountains.

Not developed as an aquifer, in part because overlying and underlying formations are better aquifers.

Yield to wells differs greatly because the permeability is secondary. However, many wells on the east side of the Bighorn Basin that penetrate rocks in this geologic unit have artesian flows in excess of 1,000 gallons per minute. This unit occurs at great depth east of the mountains and is not commonly developed for water supplies. 


\section{SUPPLEMENTAL INFORMATION--Continued}

\section{Description of Geologic Units and Potential Availability of Ground Water in Park County, Wyoming-Continued}

DARBY FORMATION--yellow, greenish-gray shale

do. and dolomite siltstone underlain by fetid brown dolomite and limestone. The Darby Formation is equivalent to the Three Forks and Jefferson Formations

THREE FORKS FORMATION--Yellow, greenishgray, and dark-gray dolomitic siltstone and silty dolomite, and black fissile shale.

Thickness 0 to 72 feet.

JEFFERSON FORMATION--Fetid brown do. dolomite and light-gray and tan limestone. Thickness 200 to 300 feet.

BEARTOOTH BUTTE FORMATION--Stream-channel do. deposit of red calcareous siltstone, red and yellowish-gray silty limestone and siltstone, limestone conglomerate, and breccia. Thickness 0 to 150 feet.

BIGHORN DOLOMITE--Gray massive cliff-forming do. dolomite and dolomitic limestone. Thickness 300 to 460 feet.

\section{GALLATIN LIMESTONE GROUP:}

SNOWY RANGE FORMATION--Gray-green shale and greenish-colored flat-pebble conglomerate. Grove Creek Limestone Member at top is gray, buff, and orange limestone and dolomite, green shale, and gray-green limestone-pebble conglomerate. Thickness 300 to 345 feet.

PILGRIM LIMESTONE--Massive light-gray do. mottled oolitic limestone. Thickness 100 to $120 \mathrm{ft}$. micaceous shale, thin-bedded gray limestone, and limestone-pebble conglomerate in upper two-thirds of formation overlying a ledge-forming unit of gray nodular thin-bedded limestone 0 to 45 feet thick. Lower third of formation interbedded dark-greenishgray micaceous shale and gray fine-grained micaceous sandstone. Thickness 450 to 660 feet. 


\section{SUPPLEMENTAL INFORMATION--Continued}

Description of Geologic Units and Potential Availability of Ground Water in Park County, Wyoming--Continued

FLATHEAD SANDSTONE--Hard ledge-forming reddish-or yellowish-colored quartzitic sandstone, locally conglomeratic at base; softer and brown speckled in upper part. Thickness 70 to $150 \mathrm{feet}$.

PRECAMBRIAN ROCKS--Gneiss.
Yields sufficient quantities of water for irrigation in other parts of the Bighorn Basin, but occurs only at great depth in area east of the mountains in Park County.

Will yield water from fractures or weathered zones in adequate quantities for stock or domestic use. Obtaining a supply at shallow depth is uncertain and drilling to depths more than 200 feet often does not result in increased yield in this geologic unit.

\footnotetext{
${ }^{1}$ Lithologic descriptions modified from Pierce (1978) and from Love and Christiansen (1985).
} 


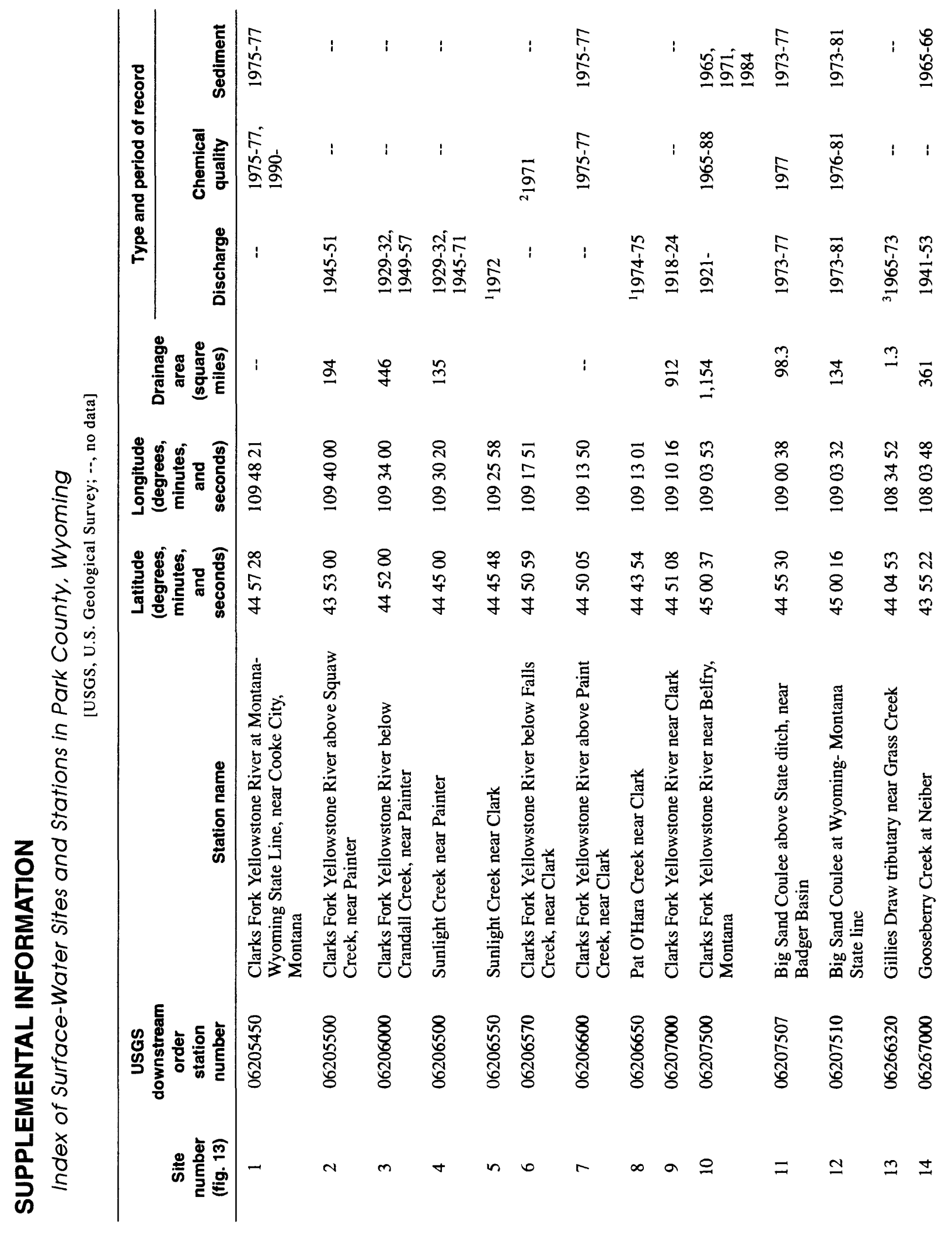




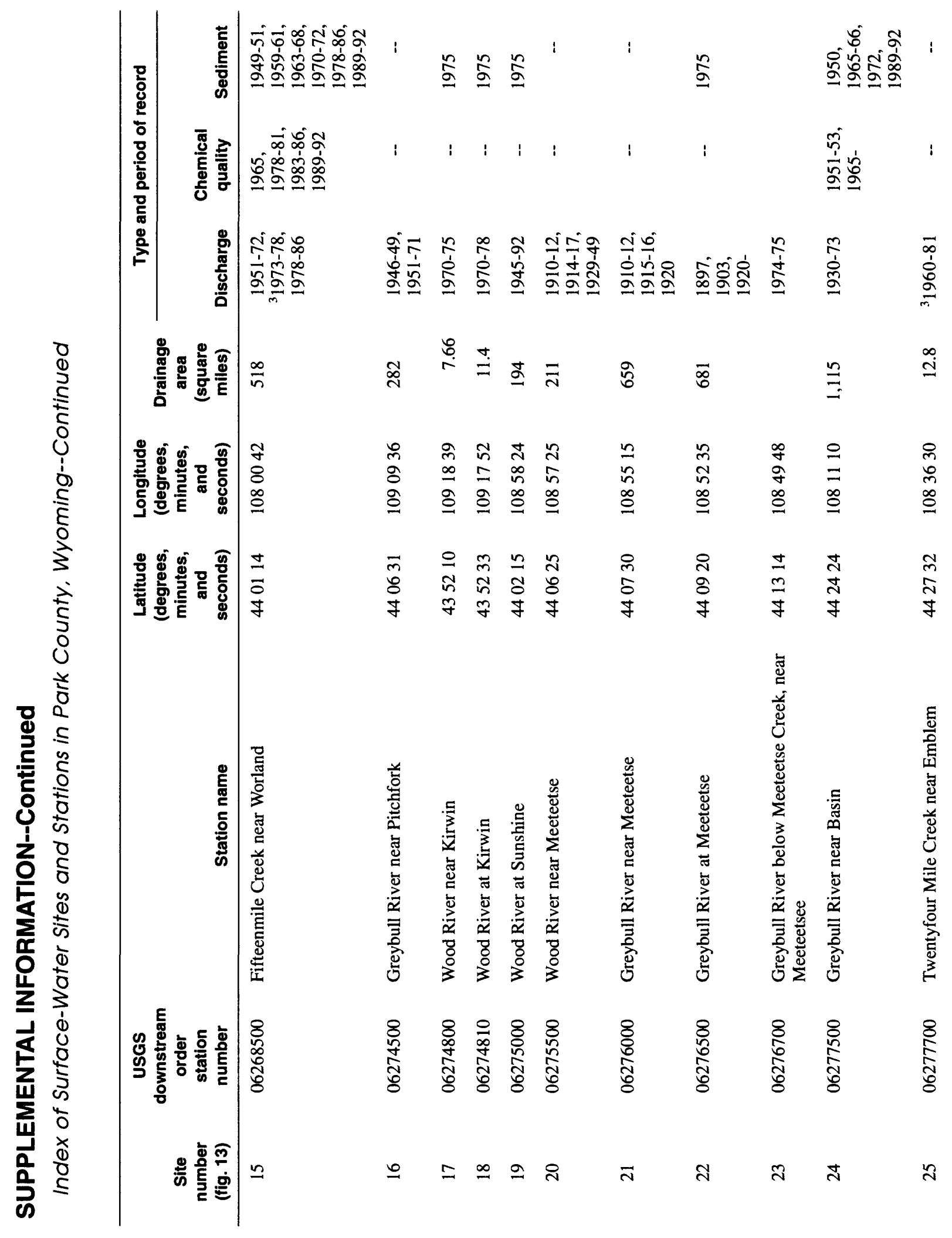




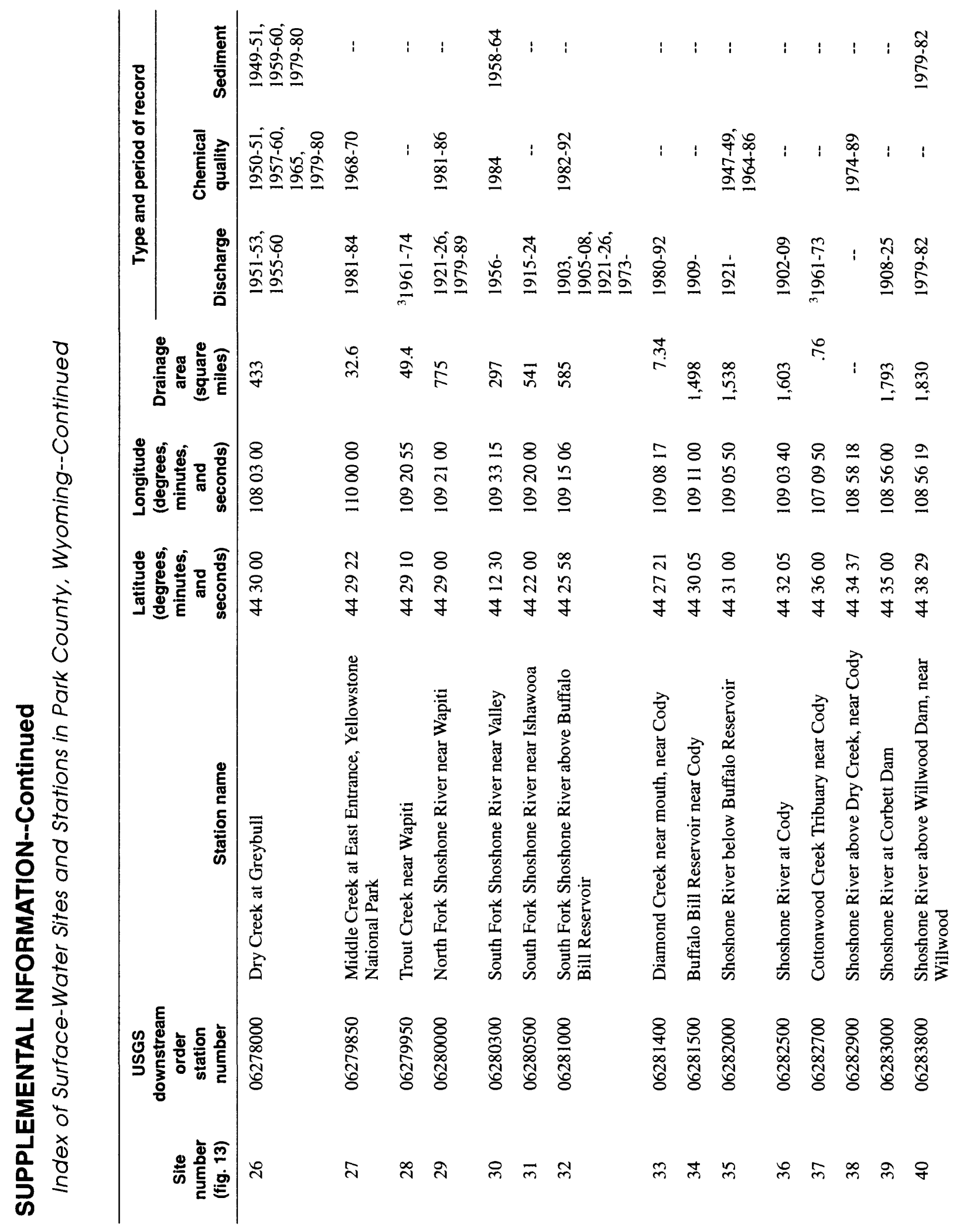




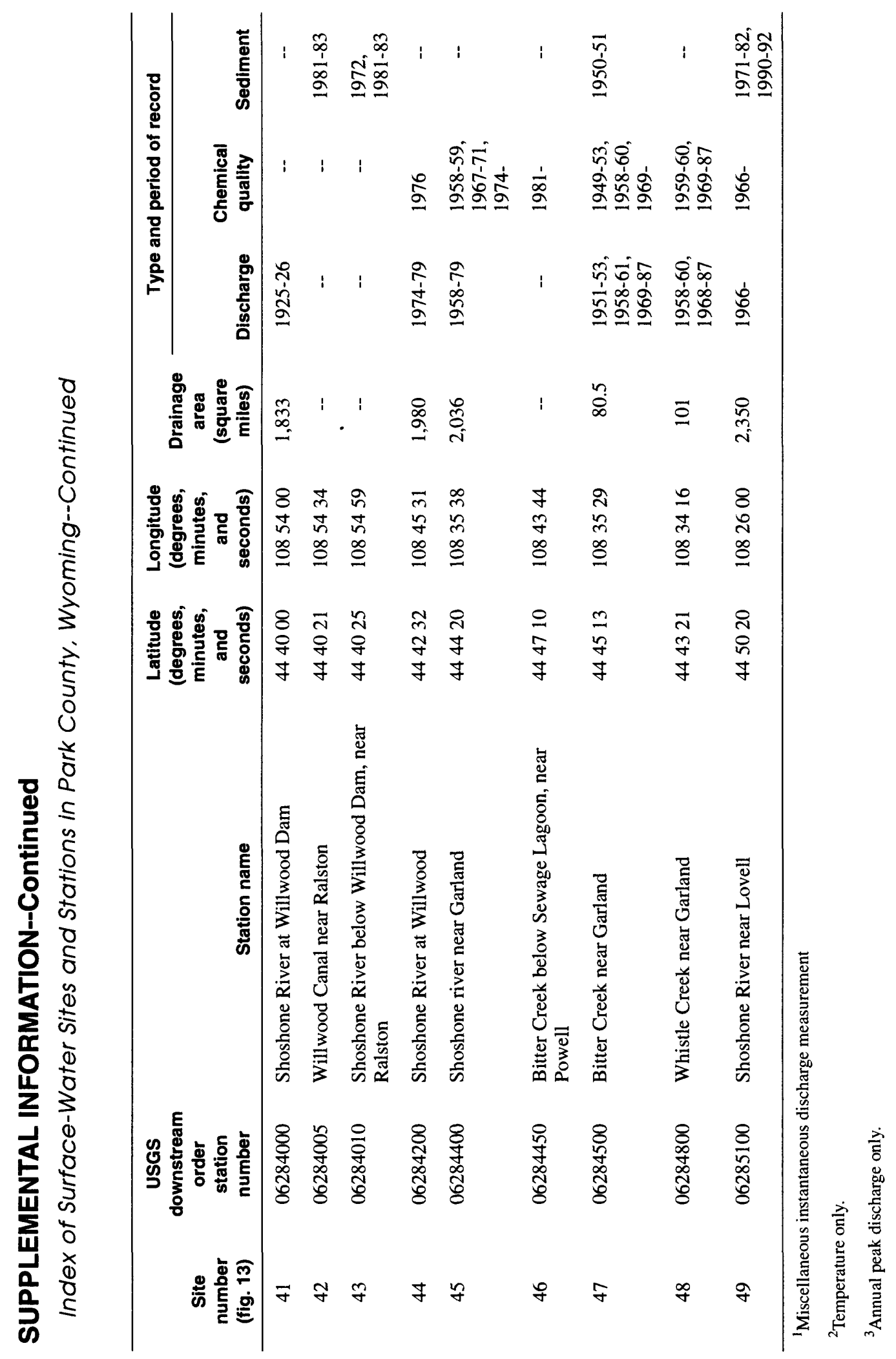




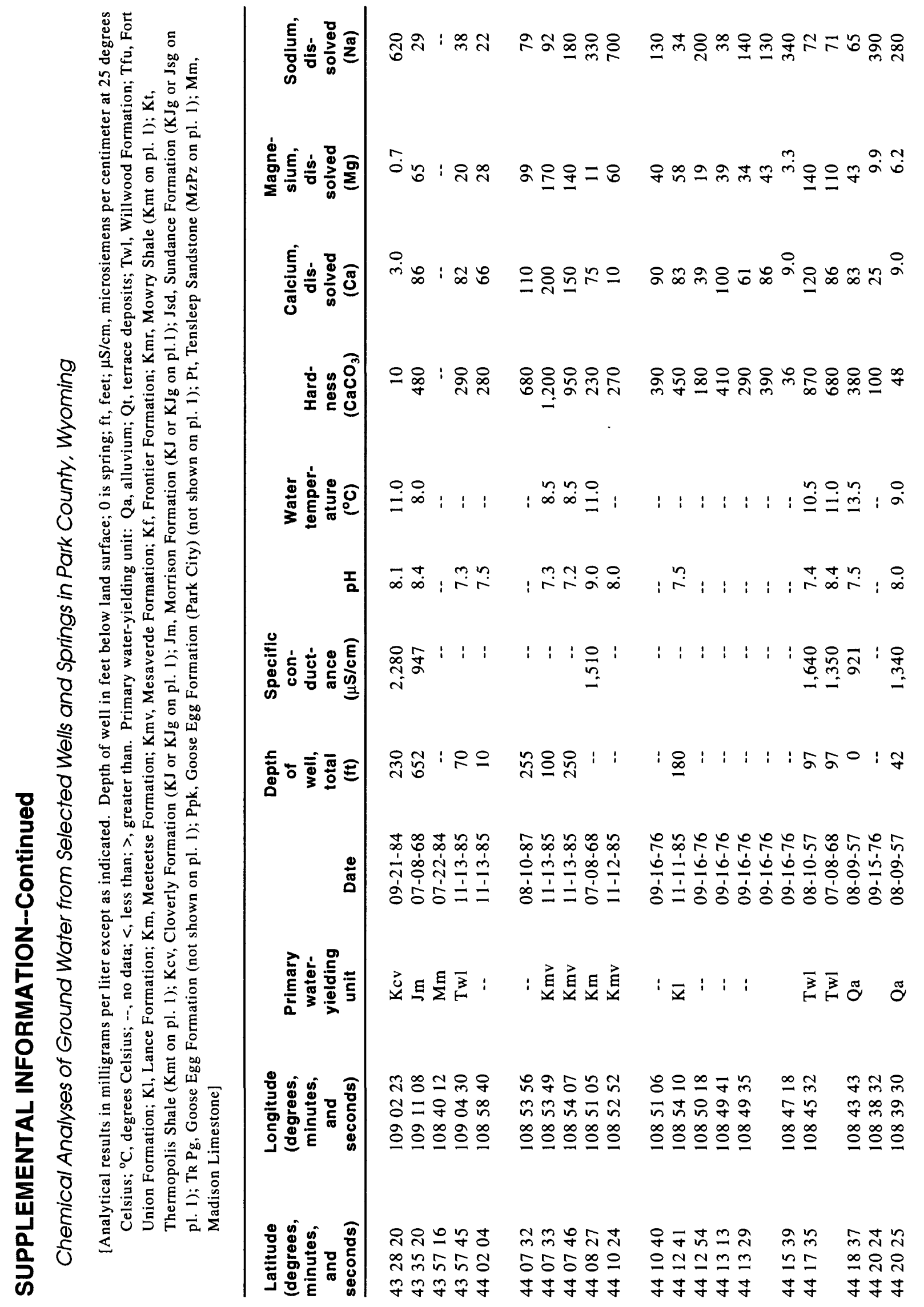




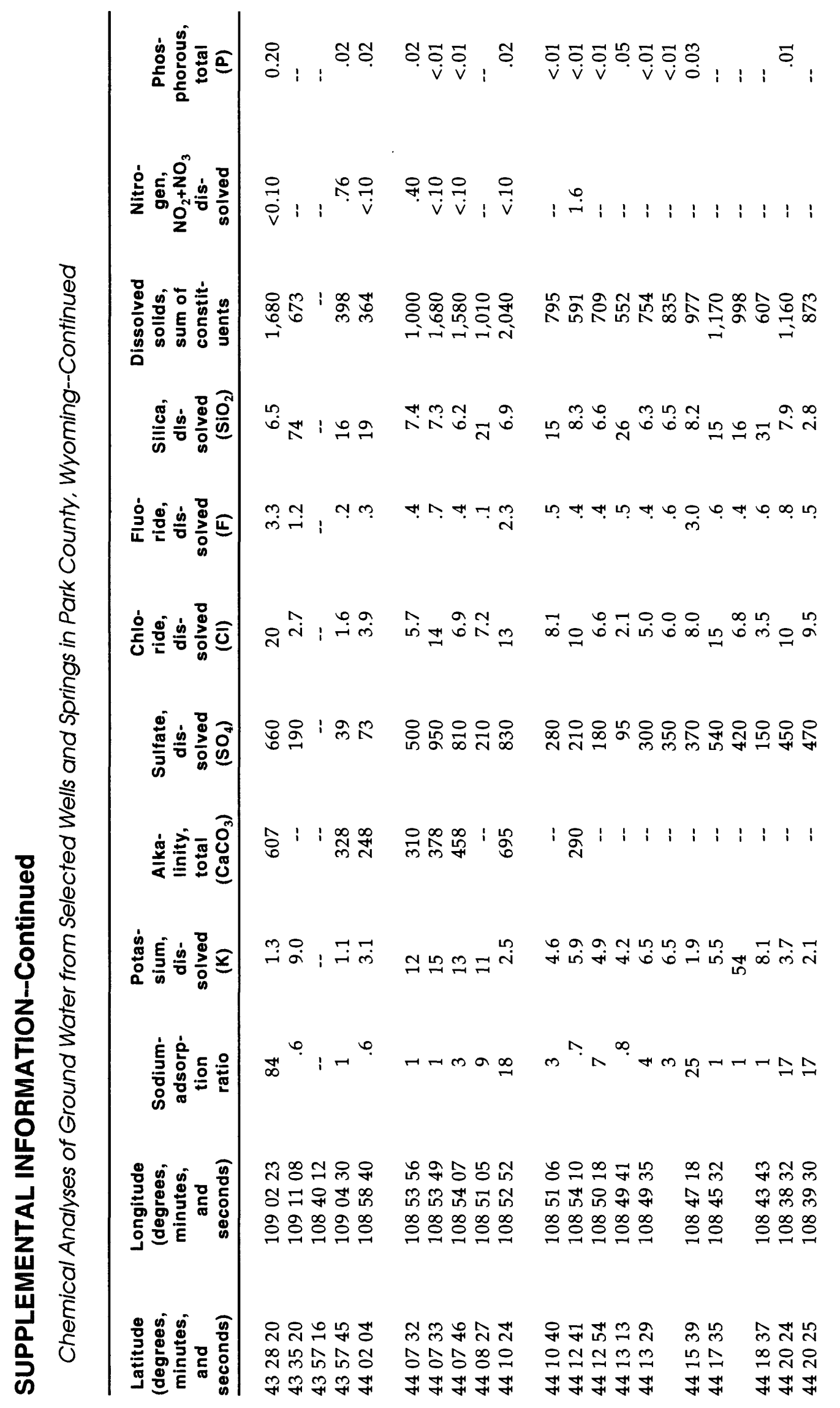




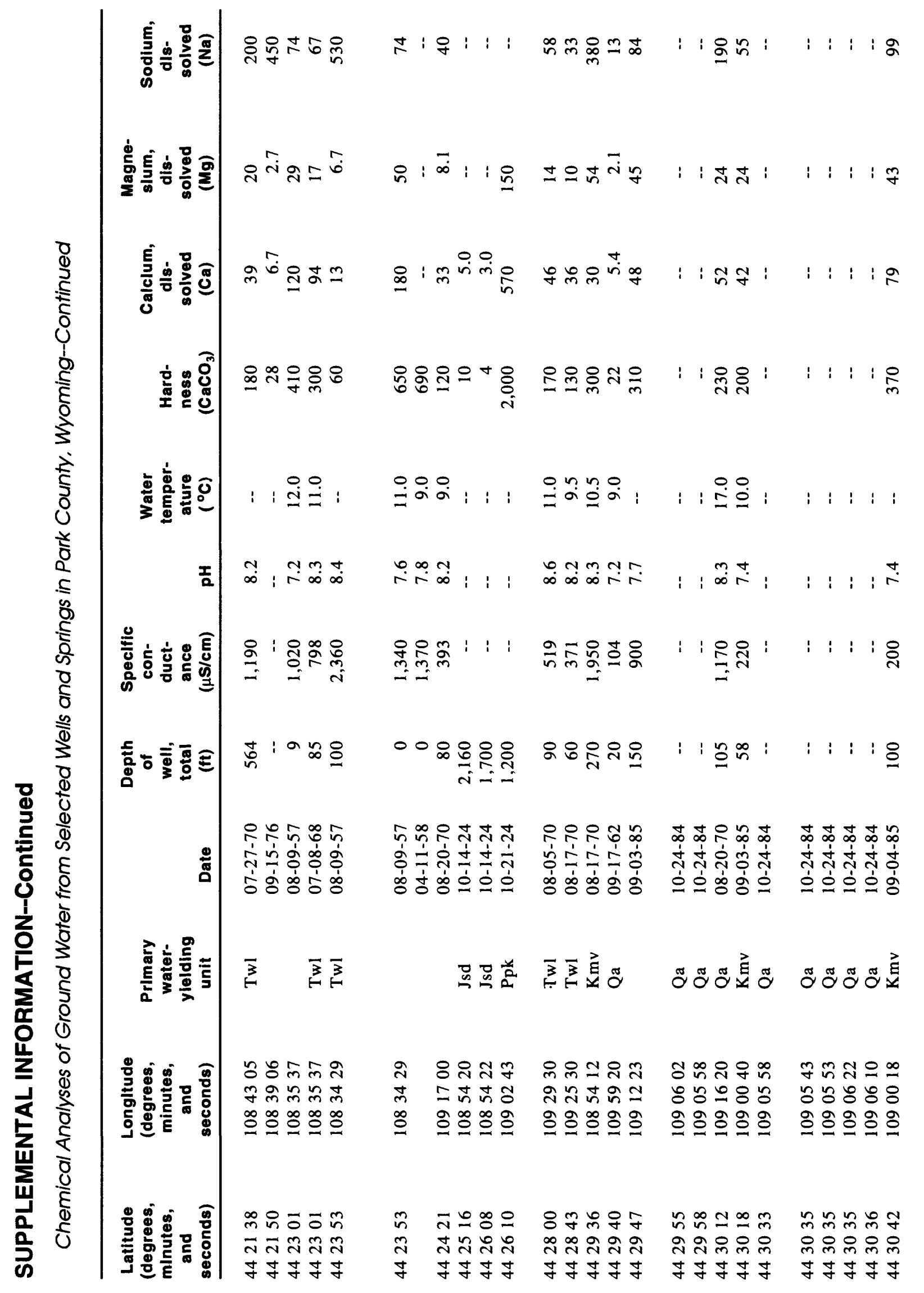




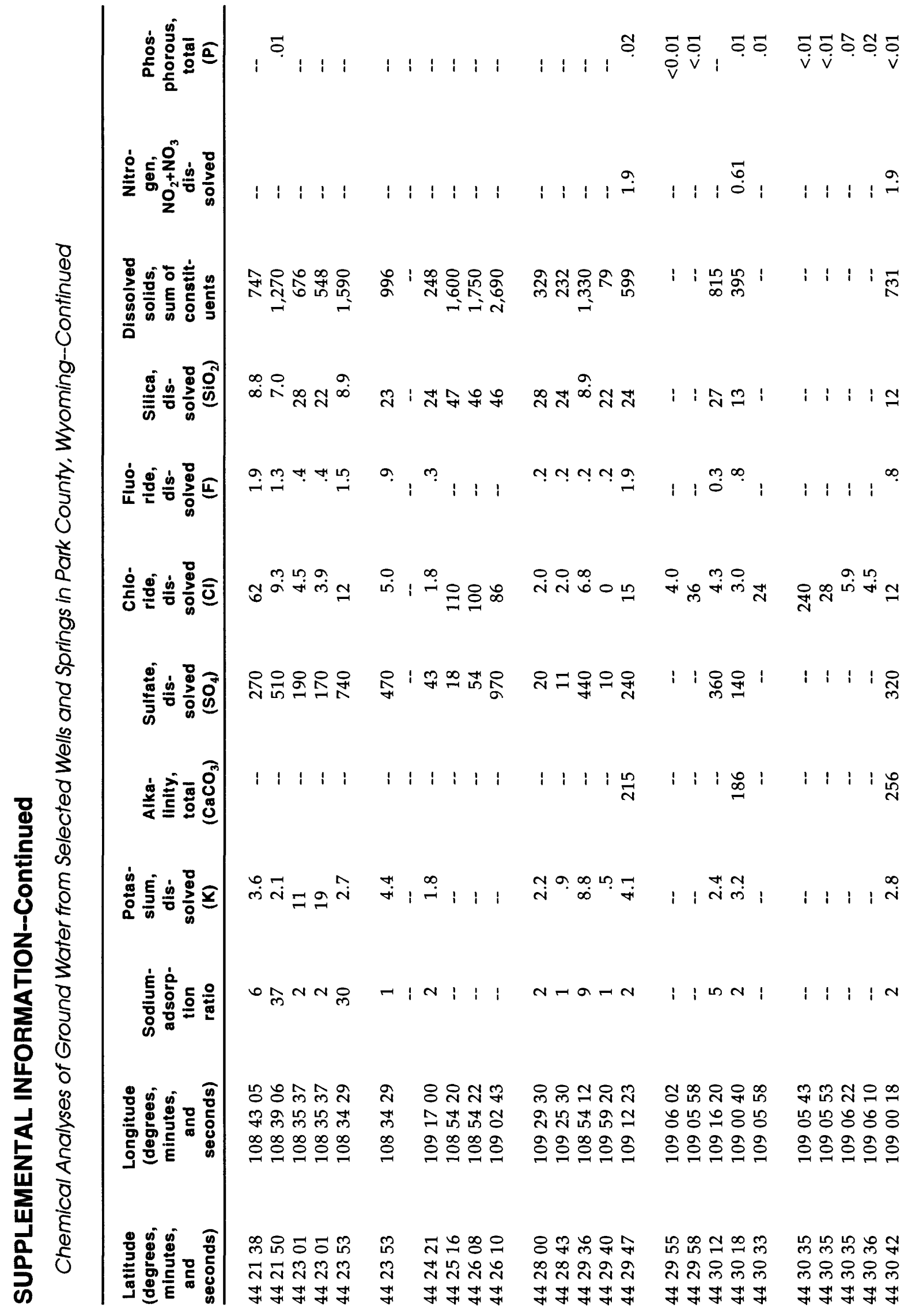




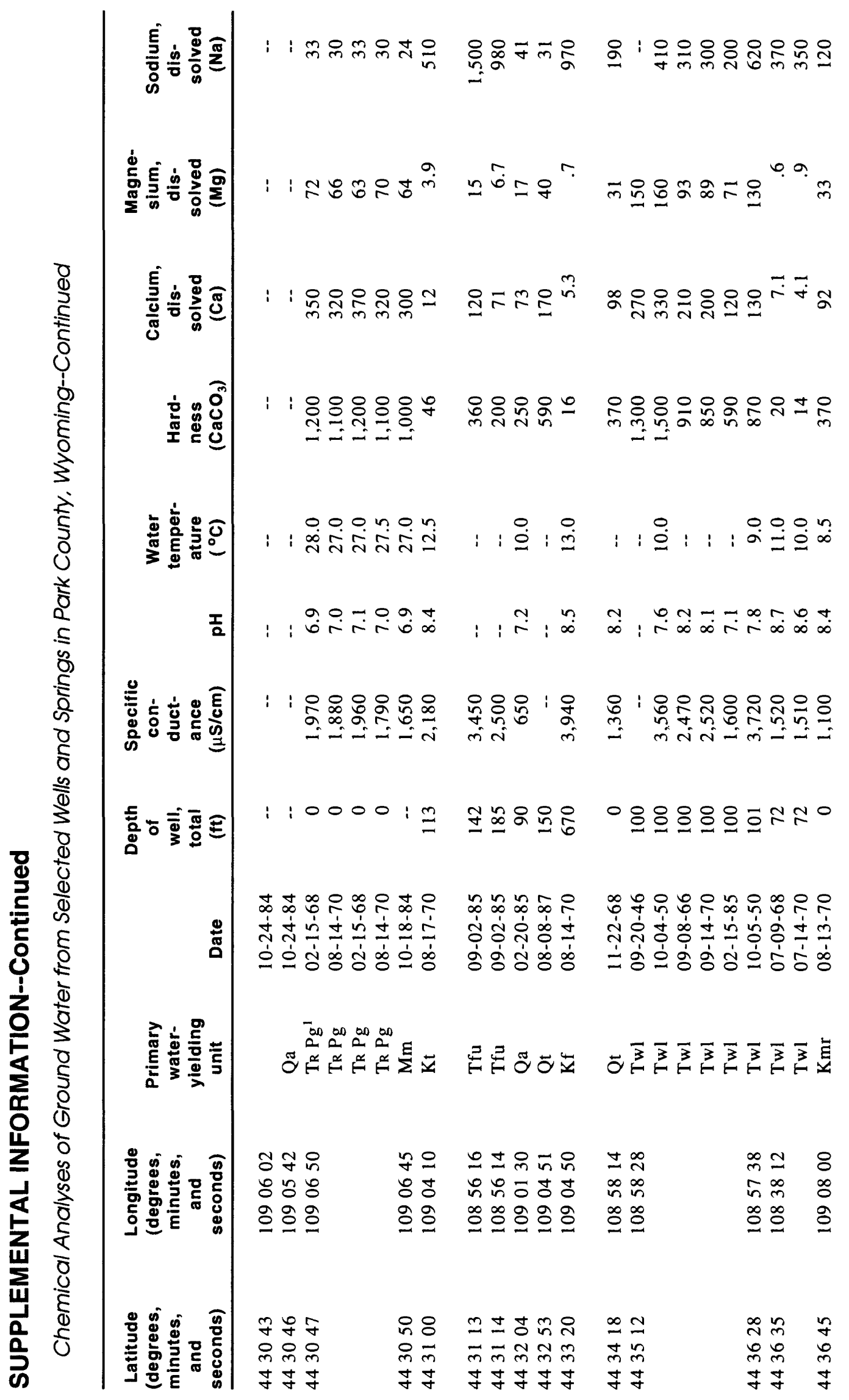




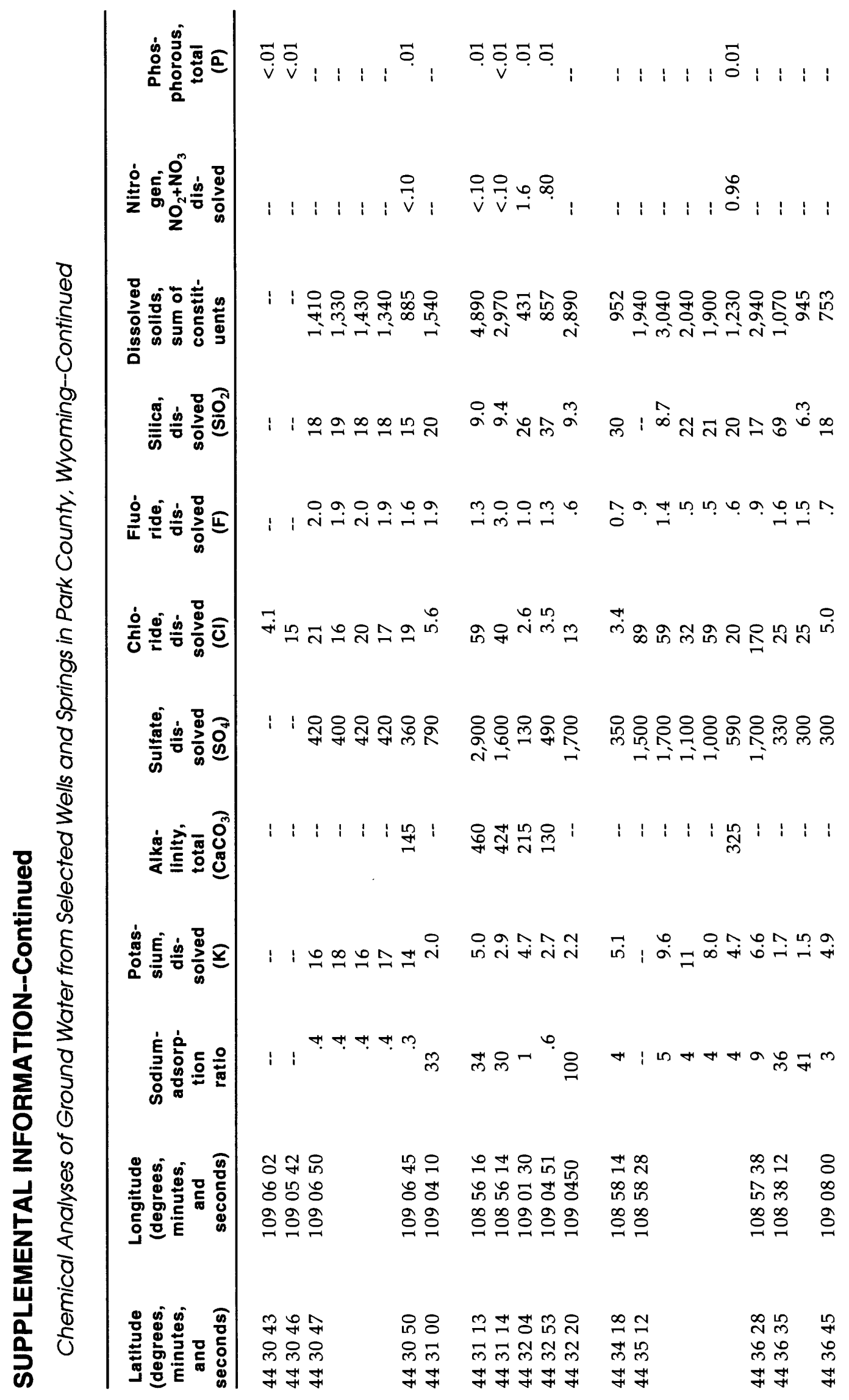




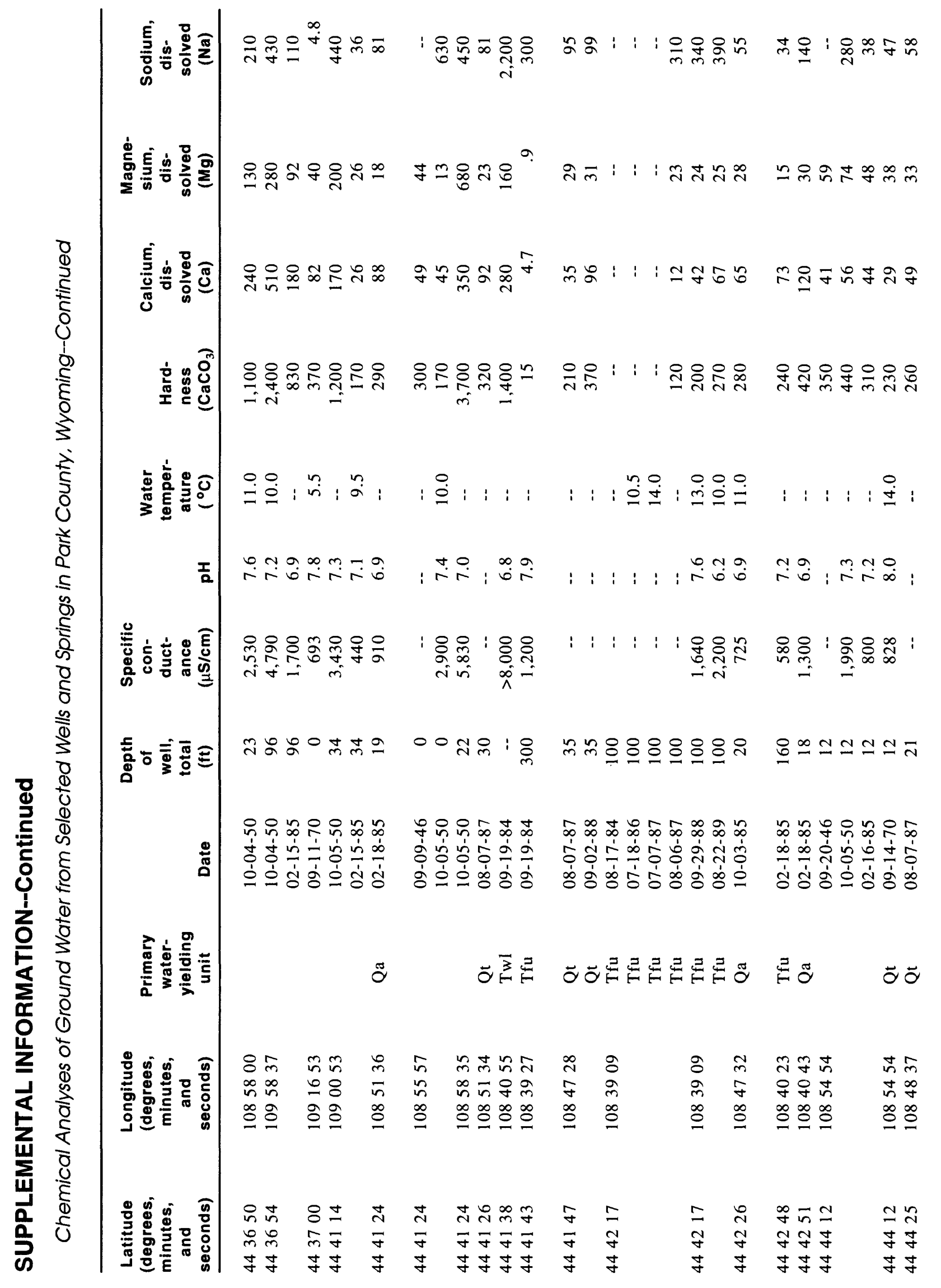




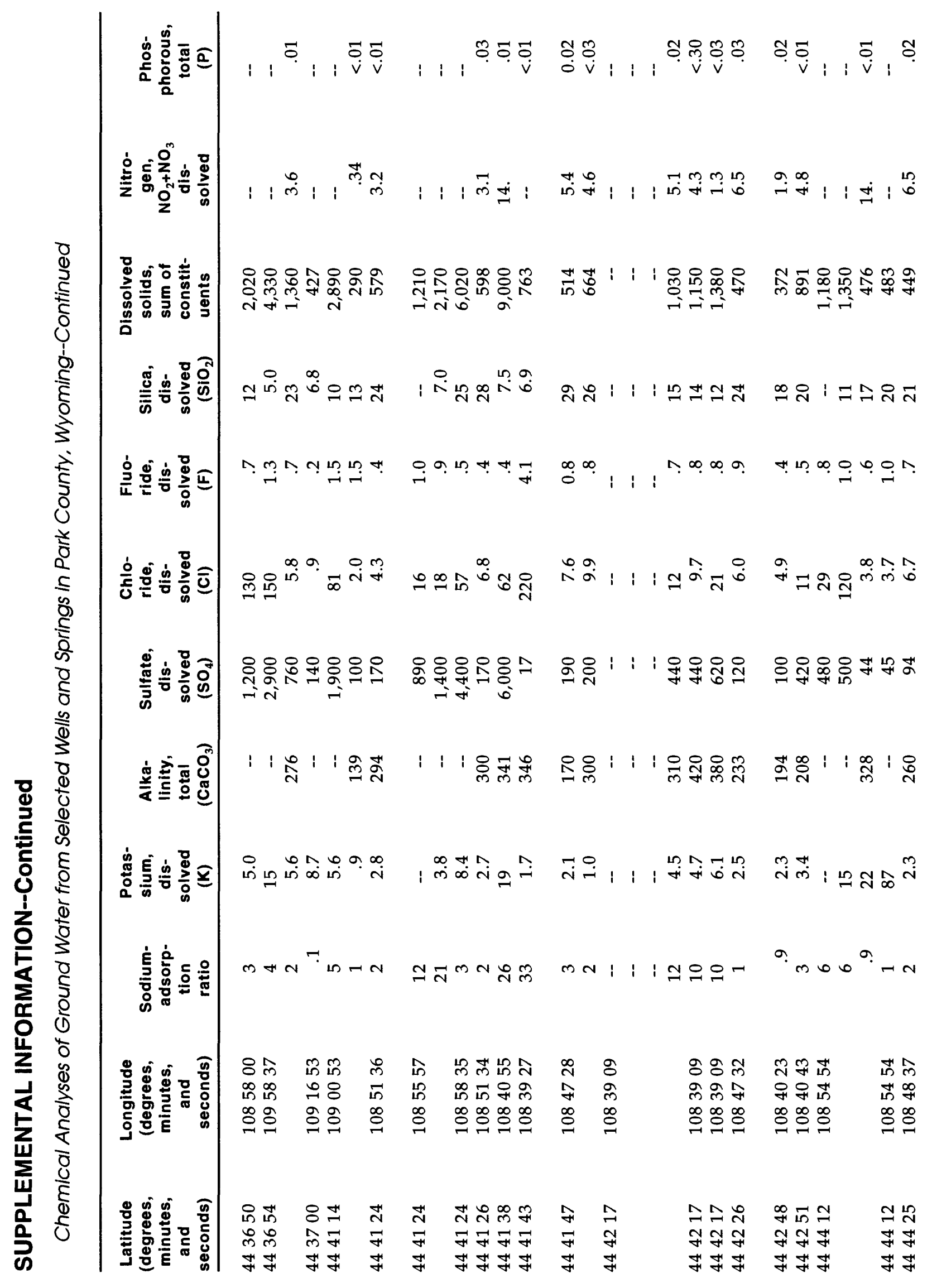




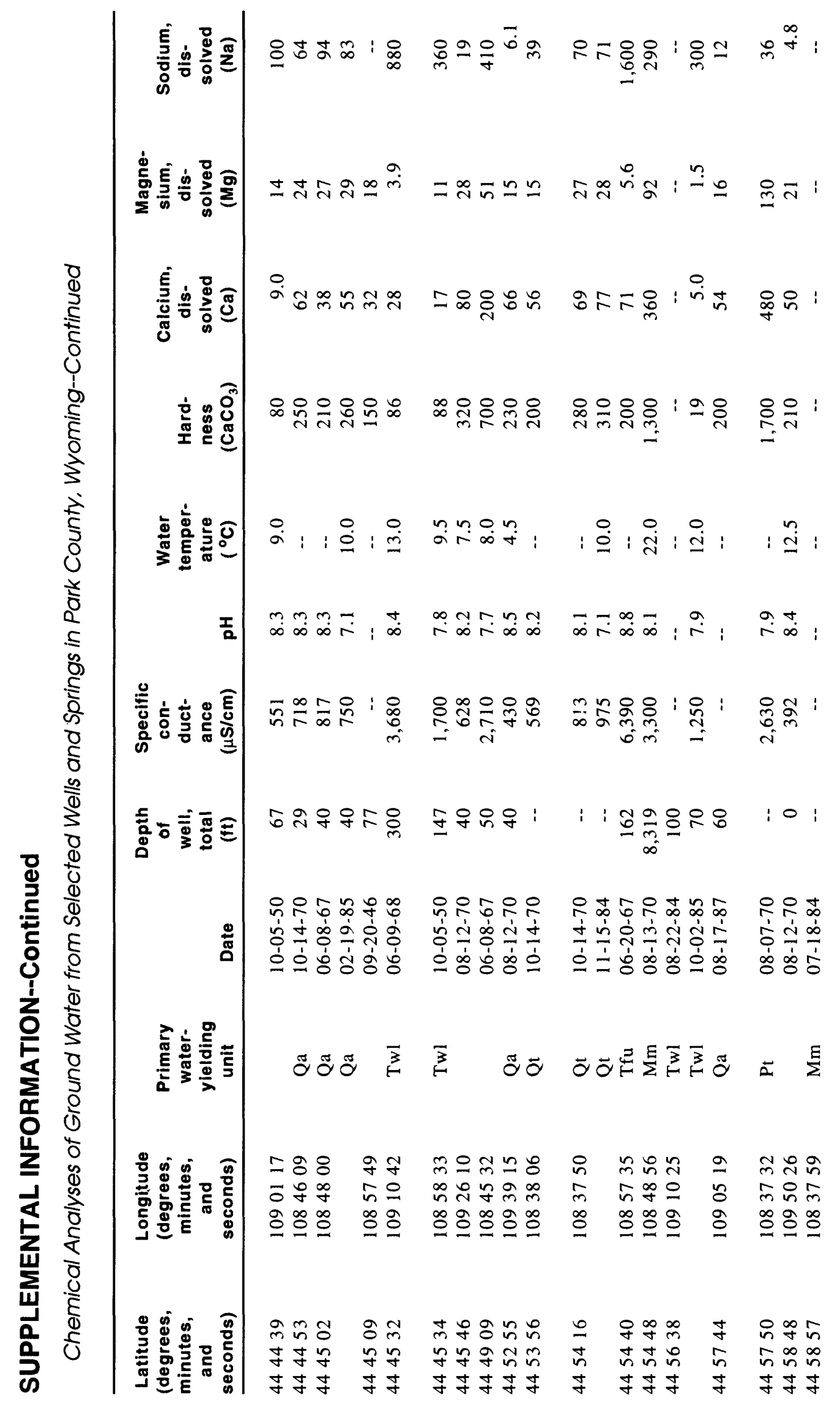




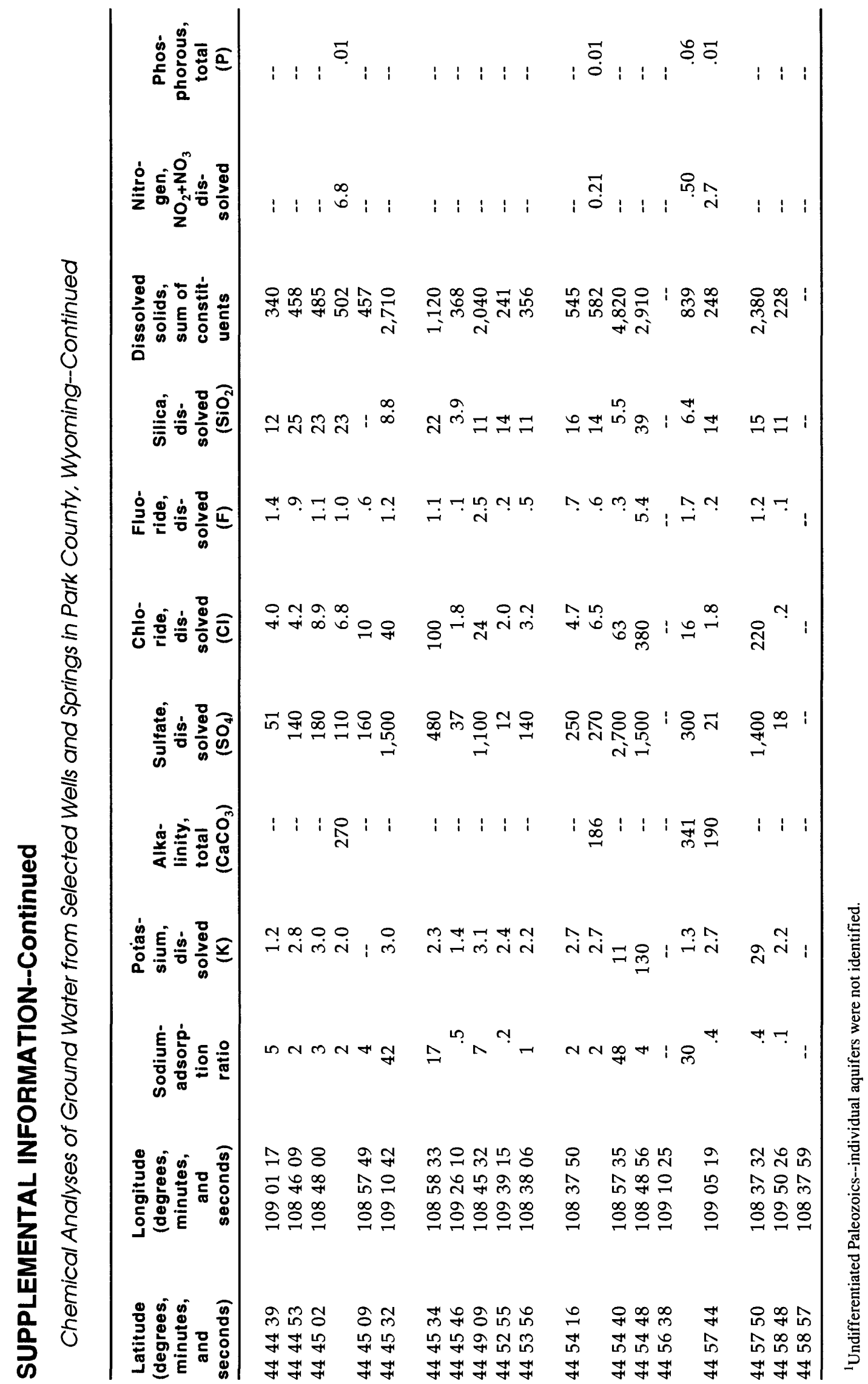

